\title{
Analysis and \\ Computer Simulation of \\ Stream-Aquifer Hydrology, \\ Arkansas River Valley, \\ Southwestern Kansas
}

By R. A. Barker, L. E. Dunlap, and C. G. Sauer

Prepared in cooperation with the Kansas State Board of Agriculture,

Division of Water Resources 


\section{UNITED STATES DEPARTMENT OF THE INTERIOR}

JAMES G. WATT, Secretary

GEOLOGICAL SURVEY

Dallas L. Peck, Director

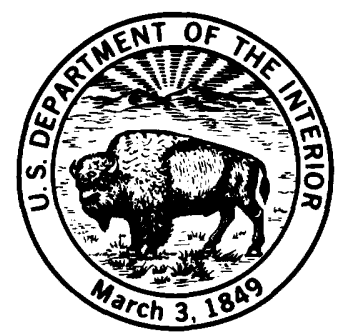

For sale by the Branch of Distribution

U.S. Geological Survey

604 South Pickett Street

Alexandria, VA 22304

Library of Congress Cataloging in Publication Data

Barker, R. A.

Analysis and computer simulation of stream-aquifer hydrology, Arkansas River valley, southwestern Kansas.

(U.S. Geological Survey Water-Supply Paper ; 2200)

Bibliography: $59 \mathrm{p}$.

Supt. of Docs. No.: I 19.76:2200

1. Hydrology-Arkansas Valley-Simulation methods.

I. Dunlap, L. E. II. Sauer, C. G. III. Kansas. State Board of Agriculture. Division of Water Resources. IV. Title. V. Series: Geological Survey Water-Supply Paper ; 2200.

GB705.A83B37 551.48'09781'4 81-607134 AACR2 


\section{CONTENTS}

Definition of terms VII

Abstract 1

Introduction 1

Purpose and scope 3

Methods of investigation 3

Digital-computer model $\mathbf{3}$

Data collection and previous investigations 3

Well-numbering system 5

Acknowledgments 5

Environmental setting 6

Geohydrology 6

Ground water 8

Surface water 8

Ground- and surface-water relationships 9

Climate 14

Land use 15

Historic hydrologic response 16

Computer-model analysis 18

Background 18

Flow equation 20

Finite-element grid and time steps 20

Calibration strategy 21

Simulated hydrologic properties

Boundary conditions 23

Streamflow 24

Hydraulic conductivity 25

Specific yield 26

Vertical flux 26

Pumpage 26

Stream-aquifer leakage $\mathbf{3 0}$

Deep percolation 31

Ground-water evapotranspiration 32

Simulated hydrologic response 34

Historic situations 34

Steady state 34

Transient 34

Water budget 37

Hypothetical situations $\mathbf{3 8}$

1970-79 38

$1980-82 \quad 41$

Sensitivity tests $\mathbf{5 3}$

Summary $\mathbf{5 3}$

References 55

PLATE

1. Map showing irrigated cropland and location of irrigation wells, diversion canals, and model boundary, Arkansas River valley, southwestern Kansas (in pocket)

\section{FIGURES}

1. Map showing location of moratorium, study, and model areas 2

2. Map showing location of streamflow-gaging stations and observation wells 4 
3. Map showing topography and location of sites for monitoring ground-water and surface-water relationships 5

4. Diagram showing well-numbering system 6

5. Schematic diagram of the relationships among geologic, hydrologic, and climatic processes 7

6. Map showing configuration of bedrock surface within model area 8

7. Map showing saturated thickness of Arkansas River alluvium within model area, 19799

8. Map showing depth to water table and water-table contours within model area, December 197910

9. Map showing ditch diversions, areas of ditch irrigation, and drainage system 11

10. Schematic diagram showing evolution of typical stream-aquifer system's response to well development 12

11. Graphs showing stream depletion as a function of distance and time 13

12. Graph showing probability distribution of annual precipitation at Syracuse, based on the 1894-1979 record 14

13. Graph showing rates of consumptive-use demand by predominant crops and land-use categories, $1979 \quad 15$

14. Graphs showing relationship among precipitation, streamflow, and groundwater levels at selected sites, 1940-79 16

15. Hydrographs showing water-level fluctuations at selected sites, 1962-79 17

16. Graph showing monthly discharge of Arkansas River near Coolidge, 1951-69 and 1970-79 18

17. Graph showing mean monthly discharge of Arkansas River near Coolidge, 1951-69 and 1970-79 19

18. Graph showing average annual diversion rates by irrigation ditches, 1951-69 and 1970-79 20

19. Graph showing average annual streamflow gain and loss of Arkansas River between Coolidge and Syracuse, 1951-79 21

20. Map showing elements and finite-element, no-flow, specified-head, and riverbed nodes within the finite-element grid 24

21. Sketch showing method of determining riverbed-reach dimensions for model input 25

22. Map showing distribution of calibrated specific yield within model area 27

23. Graphs showing annual pumpage and number of wells for 1951-69 and 1970$79 \quad 27$

24. Map showing areal distribution of pumpage from Arkansas River alluvium, 197928

25. Graph showing relationship between electric-motor horsepower and pump discharge 29

26. Graph showing average monthly distribution of total annual pumpage by irrigation and public-supply wells and of surface-water diversion through Frontier Ditch, 1970-79 30

27. Map showing areas of simulated irrigation applications within model area 32

28. Graph showing simulated rates of consumptive-use demand for 1951-69 and 1970-79 33

29. Graph showing simulated relationship between depth to water table and ground-water evapotranspiration 34

30. Map showing assumed and simulated steady-state water-level contours within model area, prior to 197035

31. Graph showing gaged and simulated mean monthly discharge of Arkansas River at Syracuse, 1951-69 36

32. Hydrograph showing measured and simulated water levels at selected sites, 1970-79 37 
33. Graphs showing gaged and simulated mean monthly discharge of Arkansas River at Syracuse (1970-79), near Kendall (1979), and downstream from Amazon Ditch headgate (1978-79) 38

34. Map showing comparison of water-level contours simulated for December 31 , 1979, and water-level altitudes measured during January 1980 within model area 39

35. Map showing location of finite-element nodes for which water levels are simulated for comparison with measured levels

36-39. Graphs showing simulated monthly rates of:

36. Precipitation, irrigation, and actual evapotranspiration, 1970-79 40

37. Deep percolation and pumpage, 1970-79 41

38. Net stream-aquifer leakage, net boundary flow, and ground-water evapotranspiration, 1970-79 41

39. Stream-aquifer leakage in four reaches of Arkansas River, 1970-79 42

40. Graph showing comparison of simulated water levels at selected sites using hypothetical (1951-69) and actual (1970-79) rates of incoming streamflow 43

41. Graph showing differences between simulated streamflow at selected sites using relation of hypothetical (1951-69) to actual (1970-79) rates of incoming streamflow $\mathbf{4 4}$

42. Graph showing comparison of simulated water levels at selected sites using hypothetical (1974-79) and actual (1970-79) rates of pumpage 45

43. Graph showing differences between simulated streamflow at selected sites using relation of hypothetical (1974-79) to actual (1970-79) rates of pumpage 46

44. Graph showing comparison of simulated water levels at selected sites using hypothetical (1951-69) and actual (1970-79) rates of precipitation 47

45. Graph showing differences between simulated streamflow at selected sites using relation of hypothetical (1951-69) to actual (1970-79) rates of precipitation 48

46-50. Graphs showing simulated water levels and average monthly streamflow during $1980-82$ at selected sites using:

46. Normal (1941-70) precipitation, 1979 pumpage, and incoming streamflow at 1979 rate (projection 1) 49

47. Normal (1941-70) precipitation, 1979 pumpage, and incoming streamflow at 1979 rate (projection 1) and 1951-69 rate (projection 2) 50

48. Normal (1941-70) precipitation, 1979 pumpage, and incoming streamflow at 1979 rate (projection 1), at 50-percent increase (projection 3), and at 50-percent decrease (projection 4) 51

49. Normal (1941-70) precipitation, incoming streamflow at 1979 rate, and pumpage at 1979 rate (projection 1), at 50-percent increase (projection 5), and at 50-percent decrease (projection 6) 52

50. 1979 pumpage, incoming streamflow at 1979 rate, and precipitation at normal 1941-70 rate (projection 1), at 25-percent increase (projection 7), and at 25-percent decrease (projection 8) 54

51-53. Graphs showing typical effects on simulated water levels and streamflow resulting from an increase and decrease in values of:

51. Aquifer hydraulic conductivity 56

52. Aquifer specific yield 57

53. Streambed leakance 58

54. Graph showing summary of recharge, discharge, and hydraulic response of stream-aquifer system in modeled area, 1951-79 59

TABLES

1. Outline of data input to model of Arkansas River valley 23

2. Simulated water budget for Arkansas River alluvium between Colorado-Kansas State line and Bear Creek Fault zone, Kearny and Hamilton Counties 


\section{Conversion Table}

Inch-pound units of measurement in this report may be converted to International System (SI) of Metric Units using the following conversion factors:

\begin{tabular}{|c|c|c|}
\hline $\begin{array}{l}\text { To convert from } \\
\text { inch-pound units }\end{array}$ & $\begin{array}{l}\text { To SI } \\
\text { units }\end{array}$ & Multiply by \\
\hline inch & millimeter & 25.4 \\
\hline foot & meter & 0.3048 \\
\hline mile & kilometer & 1.609 \\
\hline acre & square meter & 4,047 \\
\hline square mile & square kilometer & 2.590 \\
\hline acre-foot (acre-ft) & cubic meter & 1,233 \\
\hline $\begin{array}{l}\text { Cubic foot per second } \\
\left(\mathrm{ft}^{3} / \mathrm{s}\right)\end{array}$ & cubic meter per second & 0.02832 \\
\hline foot per day $(\mathrm{ft} / \mathrm{d})$ & meter per day & 0.3048 \\
\hline $\begin{array}{l}\text { foot squared per day } \\
\left(\mathrm{ft}^{2} / \mathrm{d}\right)\end{array}$ & meter squared per day & 0.0929 \\
\hline $\begin{array}{l}\text { gallon per minute } \\
\text { (gal/min) }\end{array}$ & liter per second & 0.06309 \\
\hline foot per mile $(\mathrm{ft} / \mathrm{mi})$ & meter per kilometer & 0.18943 \\
\hline $\begin{array}{l}\text { acre-foot per year } \\
\text { (acre-ft/yr) }\end{array}$ & cubic meter per year & 1,233 \\
\hline $\begin{array}{l}\text { foot per second } \\
(\mathrm{ft} / \mathrm{s})\end{array}$ & meter per second & 0.02832 \\
\hline $\begin{array}{l}\text { inch per year } \\
\text { (in/yr) }\end{array}$ & millimeter per year & 25.4 \\
\hline $\begin{array}{l}\text { foot per year } \\
(\mathrm{ft} / \mathrm{yr})\end{array}$ & meter per year & 0.3048 \\
\hline $\begin{array}{l}\text { kilowatt hour per acre- } \\
\text { foot per foot [(kWh/ } \\
\text { acre-ft)/ft] }\end{array}$ & $\begin{array}{l}\text { joule per cubic hectometer } \\
\text { per meter }\end{array}$ & $9.58 \times 10^{9}$ \\
\hline $\begin{array}{l}\text { cubic foot per acre-foot } \\
\text { per foot }\left[\left(\mathrm{ft}^{3} / \text { acre- }\right.\right. \\
\mathrm{ft}) / \mathrm{ft}]\end{array}$ & $\begin{array}{l}\text { liter per cubic hectometer } \\
\text { per meter }\end{array}$ & $7.536 \times 10^{4}$ \\
\hline horsepower & watt & 746.0 \\
\hline square foot & square meter & 0.09290 \\
\hline
\end{tabular}




\section{DEFINITION OF TERMS}

Aquifer - A formation, group of formations, or part of a formation that contains sufficient saturated material to yield significant quantities of water to wells or springs.

Consumptive use - Volume of water that is used by vegetative growth in transpiration and building of plant tissue and that is evaporated from adjacent soil or intercepted precipitation on plant foliage.

Deep percolation - Volume of water from precipitation and irrigation that infiltrates the soil and moves by the force of gravity to the water table.

Ephemeral stream - Stream that flows briefly in direct response to precipitation in the immediate locality and has a channel that is, at all times, above the water table.

Evapotranspiration - Volume of water that is lost to the atmosphere by transpiration from vegetative growth and by evaporation from the soil or from the aquifer in shallow water- table areas.

Hydraulic conductivity - Volume of water at the existing kinematic viscosity that will move through a porous medium in unit time under a unit hydraulic gradient through a unit area measured at right angles to the direction of flow.

Hydraulic gradient - Rate of change in hydraulic head per unit of distance of flow in a given direction.

Hydraulic head - Height of the surface of a column of water above a standard datum that can be supported by the pressure at a point.

Incident water - Total volume of water on the land surface from precipitation and irrigation that may run off directly to streams, infiltrate to deep percolation, or be transferred to the atmosphere by evapotranspiration.

Leakance - Ratio of the vertical hydraulic conductivity of the streambed to the thickness of the streambed material.

Moisture-holding capacity - Volume of water that may be retained in the soil zone for eventual consumption by evapotranspiration.

Perennial stream - Stream that flows throughout the year and has a channel that generally is below the water table.

Specific yield - Ratio of the volume of water that the saturated material will yield by gravity drainage to the volume of the material.

Steady state - Equilibrium conditions when hydraulic heads and the volume of water in storage do not change significantly with time.

Storage coefficient - Volume of water an aquifer releases from or takes into storage per unit surface area of the aquifer unit change in head.

Transient state - Nonequilibrium conditions when hydraulic heads and the volume of water in storage do change significantly with time.

Transmissivity - Rate at which water of the prevailing kinematic viscosity is transmitted through a unit width of an aquifer under a unit hydraulic gradient. 
1 


\title{
Analysis and Computer Simulation of Stream-Aquifer Hydrology, Arkansas River Valley, Southwestern Kansas
}

\author{
By R. A. Barker, L. E. Dunlap, and C. G. Sauer
}

\section{Abstract}

A study was made, in cooperation with the Division of Water Resources, Kansas State Board of Agriculture, to determine geohydrologic conditions underlying nearly 110,000 acres of the Arkansas River Valley between the Colorado-Kansas State line and the Bear Creek Fault zone in southwestern Kansas. The Arkansas River meanders atop and interacts hydraulically with the area's un-, confined sand and gravel aquifer. Owing to decreasing recharge and increasing discharge during the 1970's, water levels declined an average of 4 feet during 1970-79. Average annual streamflow at Syracuse, Kansas, also decreased from 232 cubic feet per second during 1951-69 to 85 cubic feet per second during 1970-79.

A digital-computer model was calibrated to simulate the trends of historic water levels and streamflow during 1970-79. Simulated 1975-79 conditions depict an annual recharge to the aquifer of 15,000 acre-ft (acre-feet) from river leakage, 9,000 acre-ft from boundary inflow, and 50,000 acre-ft from deep percolation. Simulated annual discharge consists of 12,000 acre-ft to boundary outflow across the Bear Creek Fault zone, 1,000 acre- $\mathrm{ft}$ as leakage to the Arkansas River, 11,000 acre-ft to groundwater evaporation, and 57,000 acre-ft to pumpage. Simulated annual recharge was 7,000 acre-ft less than simulated annual discharge of 81,000 acre-ft.

Simulation indicates that: (1) The long-term effects of less recharge from smaller than average amounts of annualprecipitation during the 1970's were offset by more recharge during brief, timely periods of much greater than the mean monthly amounts of precipitation, and (2) the effects of the increased pumpage were partly offset by increased recharge resulting from increased irrigation. Model results indicate that the water-level decline and streamflow shortage during 1970-79 were affected more directly by departures from historic (1951-69) rates of incoming streamflow than by either the smaller than average amounts of precipitation or the increased pumpage during the 1970 's. Results also indicate that waterlevel declines and streamflow reduction would stabilize or reverse during 1980-82 if one of the following conditions prevailed: (1) Monthly precipitation increased to 25 percent greater than the normal for 3 years. (2) pumpage decreased to 50 percent of the 1979 rate or, (3) incoming streamflow increased to the 1951-69 rate.

\section{INTRODUCTION}

In January 1977, the Chief Engineer of the Division of Water Resources, Kansas State Board of Agriculture, declared a moratorium on the approval of applications for permits to appropriate water from an area of 500-square miles along the Arkansas River in Hamilton and Kearny Counties, southwestern Kansas (fig. 1). The moratorium was prompted by a growing concern over decreasing streamflow and declining water levels and the need for a better understanding of the ground- and surface-water interaction in the area.

Average annual streamflow at Syracuse, Kans., decreased from 173,000 acre-ft during 1951-69 to 65,000 acre-ft during 1970-79. January water levels in the western part of the moratorium area have declined about 4 feet since 1970; water levels in the eastern part of the moratorium area have declined more than 25 feet between 1970 and 1979.

Since the later 1800's, irrigation companies in Kansas have diverted water from the Arkansas River. Legal rights to this water are predominantly vested; for the most part, they are senior (earlier in time) to ground-water appropriation in the area. Because streamflow during the 1970's has been insufficient to meet legal commitments and satisfy crop demands, the area has become increasingly dependent on ground water for irrigation.

Kansas water law is based on the appropriation doctrine "first in time, first in right." The shift from surface water to ground water for irrigation has made it difficult to enforce this doctrine. In some areas, ground-water withdrawals have allegedly increased stream-channel losses, thus jeopardizing the protection of prior rights.

When the moratorium was declared, hydrologic information was insufficient to allow an adequate scientific evaluation of the interaction of ground and surface water and the extent to which diversion from either source might impair water use under existing rights. Other considerations not properly understood were the effects of drought and year-to-year decreases in streamflow at the State line during the 1970's. Certainly, there were several factors contributing to the water shortage, but what was the relative importance of each? What effect would each factor have under future conditions? 


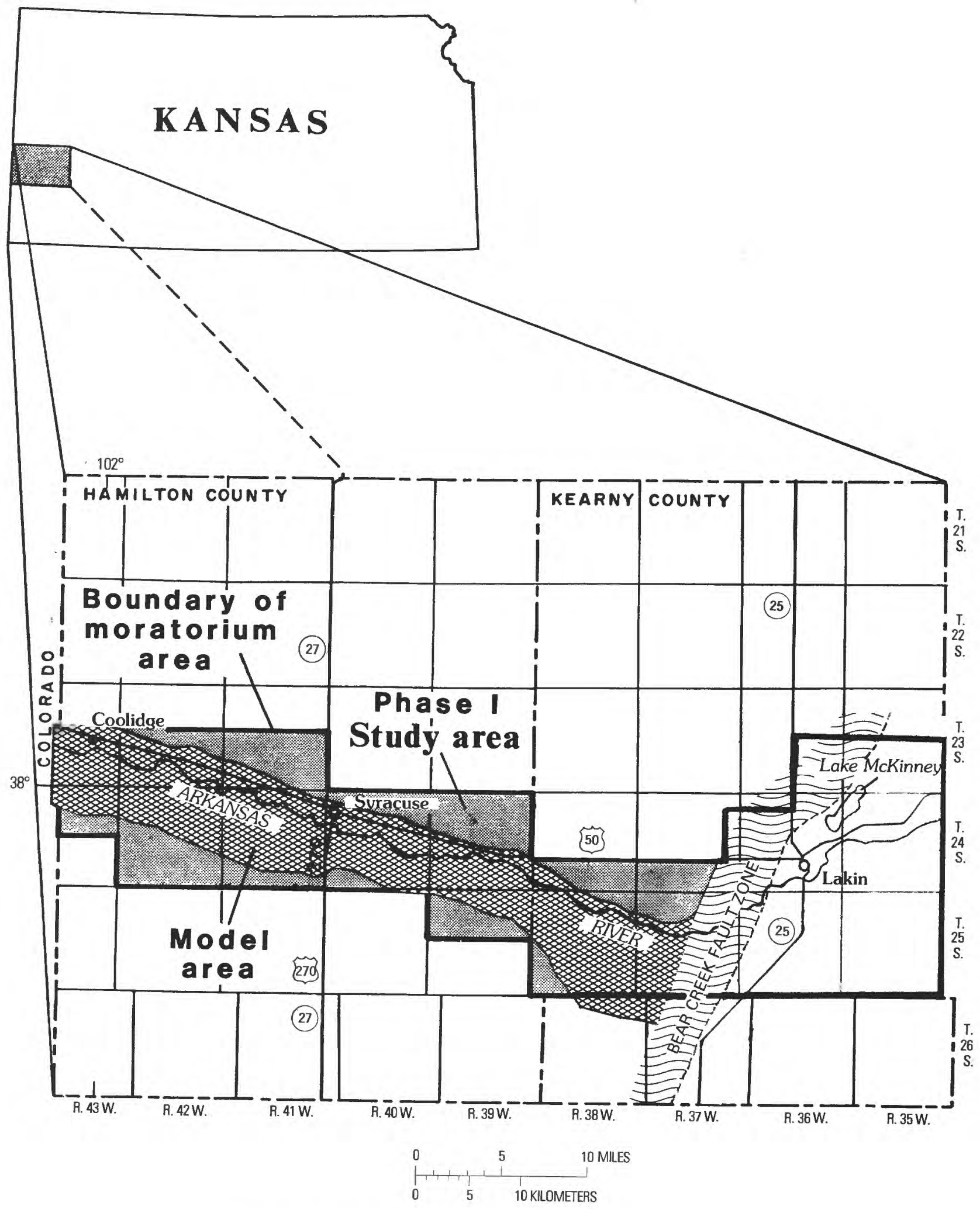

Figure 1. Location of moratorium, study, and model areas. 
These and other questions had to be addressed before equitable judgments could be made by the Division of Water Resources on applications for additional development of the water resources under the Kansas Water Appropriations Act. In particular, a thorough geohydrologic investigation of the area was needed to assess future hydrologic conditions in anticipation of possible rates of: (1) pumpage, (2) streamflow at the State line, and (3) precipitation. Owing to water-management problems associated with a generally inadequate water supply and the need to better understand the stream-aquifer system, the Division of Water Resources in October 1977 entered into a 5-year cooperative investigation of the moratorium area with the U.S. Geological Survey.

\section{Purpose and Scope}

The purpose of the investigation was to: (1) better define the relationships among ground water, surface water, and climatic factors, (2) evaluate the effects of ground-water withdrawals on streamflow, and (3) calibrate digital-computer models of the hydrologic systems within the State-declared moratorium area along the Arkansas River valley in Hamilton and Kearny Counties, Kans. (fig. 1).

To expedite model development, study of the moratorium area was divided into two parts (fig. 1) phase I (1977-80) and phase II (1979-82).

This report describes the geohydrology of the western two-thirds of the moratorium area, studied under phase I, and a computer model of the associated streamaquifer system. The report is written for the scientifically informed public and for State and local water agencies who may use the results of the investigation to formulate water-management policies to improve the conjunctive use of ground and surface water within the constraints of the water-right structure in Kansas.

"Study area," as it appears henceforth, refers only to that part of the moratorium area studied under phase I. "Model area" refers to the area of the stream-aquifer system between the Kansas-Colorado State line and the Bear Creek Fault zone and bounded on the north and south by bedrock.

\section{Methods of Investigation}

\section{Digital-Computer Model}

The importance of digital computers for the evaluation of water resources has increased substantially in re- cent years. The computer's ability to solve, rapidly and relatively inexpensively, repetitive sets of mathematical equations that account for the pertinent hydrologic phenomena of an area has prompted the use of digitalcomputer models for stream-aquifer studies.

The computer model of the Arkansas River valley is a program written in FORTRAN code, which solves equations of ground-water flow. In order to work, or simulate, the model requires data input; the results of model simulation are shown by output. Examples of input are bedrock altitudes and hydraulic conductivity. Water-level altitudes and streamflow are examples of output.

The model was developed under the premise that, once calibrated to simulate a sequence of observed responses to a history of hydrologic conditions, the model can then be used to predict the effects of hypothetical distributions of recharge and discharge. Because model simulation can extend into the future, the model provides a practical means of testing hydrologic response to proposed or anticipated changes in the system. In addition to indicating opportunities for water conservation, the model can demonstrate ways to improve the availability and use of both ground and surface water in the Arkansas River valley.

\section{Data Collection and Previous Investigations}

A model's utility and worthiness as a water-management aid depends on the accuracy and completeness of the data with which the model is calibrated. The use of limited calibration data might seriously jeopardize the integrity of management decisions based on model simulation. Therefore, literature searching and data collection dominated the early part of the study. When possible, previously available data were used for model development. When absent or lacking, the required data were collected during the study.

Much geohydrologic information was available from previous work. Configuration of the bedrock surface and alluvial-bedrock contacts were defined primarily on the basis of reports by Gutentag, Lobmeyer, and McGovern (1972) and Lobmeyer and Sauer (1974). McLaughlin (1943) provided historical data pertinent to early development of the area's water resources and the system's response to that development and climatic conditions.

Historcial surface-water data were obtained primarily from publications of the U.S. Geological Survey and annual reports of the Arkansas River Compact Administration. Rates of canal diversion and areas of surface-water irrigation were provided from records kept by the Division of Water Resources' office in Garden City, Kans. 
Climatic data published by the National Oceanic and Atmospheric Administration (1940-80) were used to define the time distribution of precipitation over the modeled area. These data also were used in conjunction with crop-growth data provided by the U.S. Department of Agriculture, Soil Conservation Service (1967), to determine the rates of consumptive use applicable to model calibration and projection.

Soil characteristics of the modeled area were extracted from publications of the U.S. Department of Agriculture, Soil Conservation Service $(1961,1963)$. Moisture-holding and infiltration properties of flood-plain and sand-dune soils were provided by the Kansas State University Extension office in Garden City.

The distribution of the land use and vegetal cover was determined for the study primarily by the University of Kansas Applied Remote Sensing Program, Lawrence, Kans. Landsat imagery and color infrared transparencies (July 1978 at a scale of $1: 10,000$ ) were used to obtain the required definition of land forms and drainage.

Positive exposures of the same color infrared photography were used by U.S. Geological Survey personnel to planimeter stream-reach lengths and widths for model input. The infrared imagery was used in combination with black and white aerial photography (1971 at 1:12,000 by the U.S. Department of Agriculture) to map irrigated and nonirrigated cropland and to differentiate between pre- and post-1971 agricultural development.

Data-collection activities during the study included: (1) The inventory of 160 irrigation and public-supply wells in the model area (plate 1), (2) gain-loss studies made for five reaches of the Arkansas River between Coolidge and the Bear Creek Fault zone, and (3) measurement of water levels in more than 40 observation wells (fig. 2) on a quarterly basis.

During the study, streamflow-gaging stations were installed on the Arkansas River downstream from the Amazon Ditch headgate (spring 1978) and at Kendall (spring 1979). These installations (fig. 2) were used to monitor streamflow rates downstream from Syracuse and to establish stage-discharge relationships for model calibration. Prior to the study, long-term streamflow records at gaging stations existed only near Coolidge (since 1921) and at Syracuse (since 1951).

Using hollow-stem augering equipment and plastic casing, a total of 17 observation wells were installed during August 1977 and November 1978 at 7 locations along the Arkansas River (fig. 3). The three wells at Syracuse and the single well at Kendall were equipped with continous water-level recorders. Water levels in the other wells

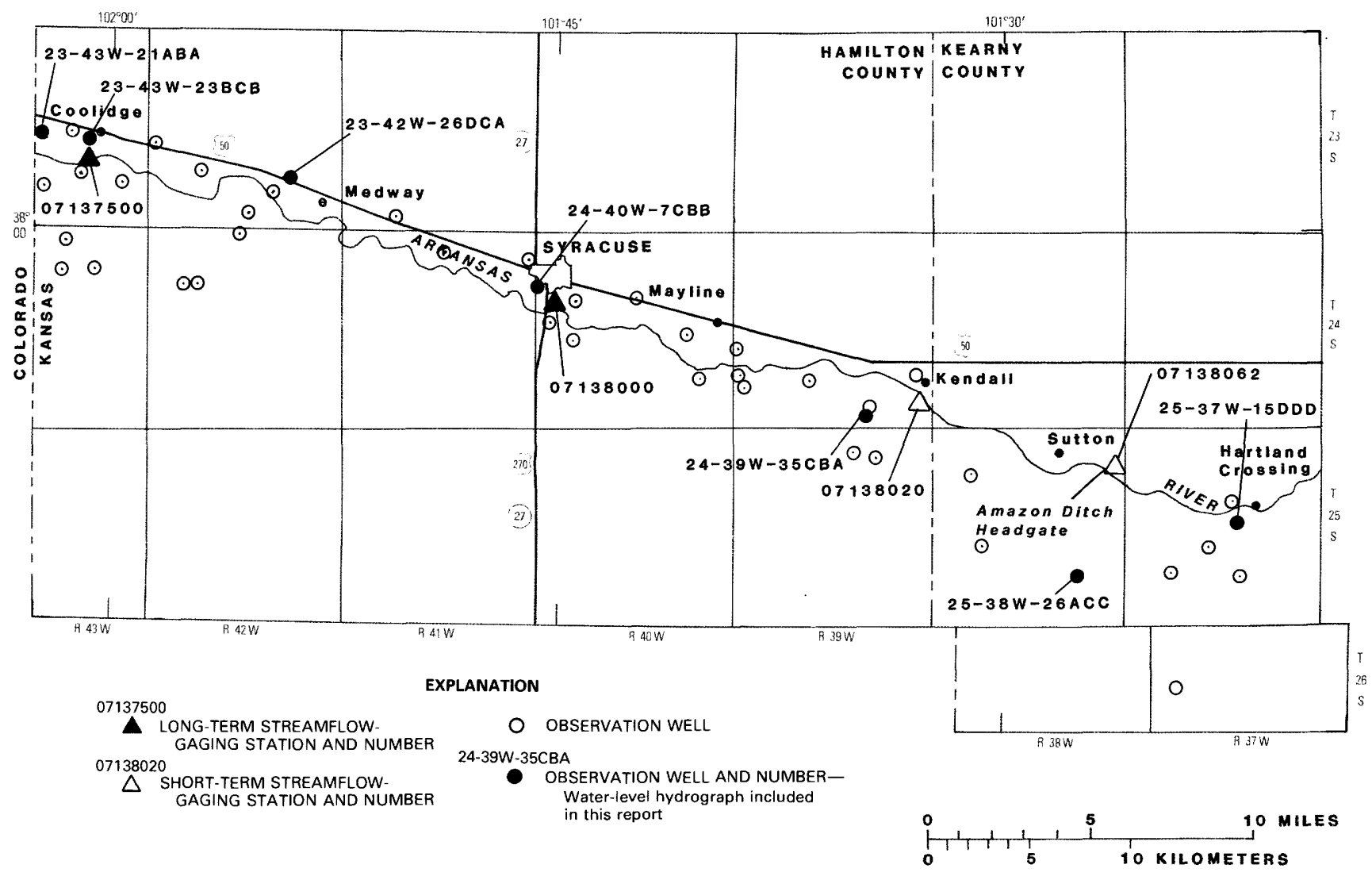

Figure 2. Location of streamflow-gaging stations and observations wells. 


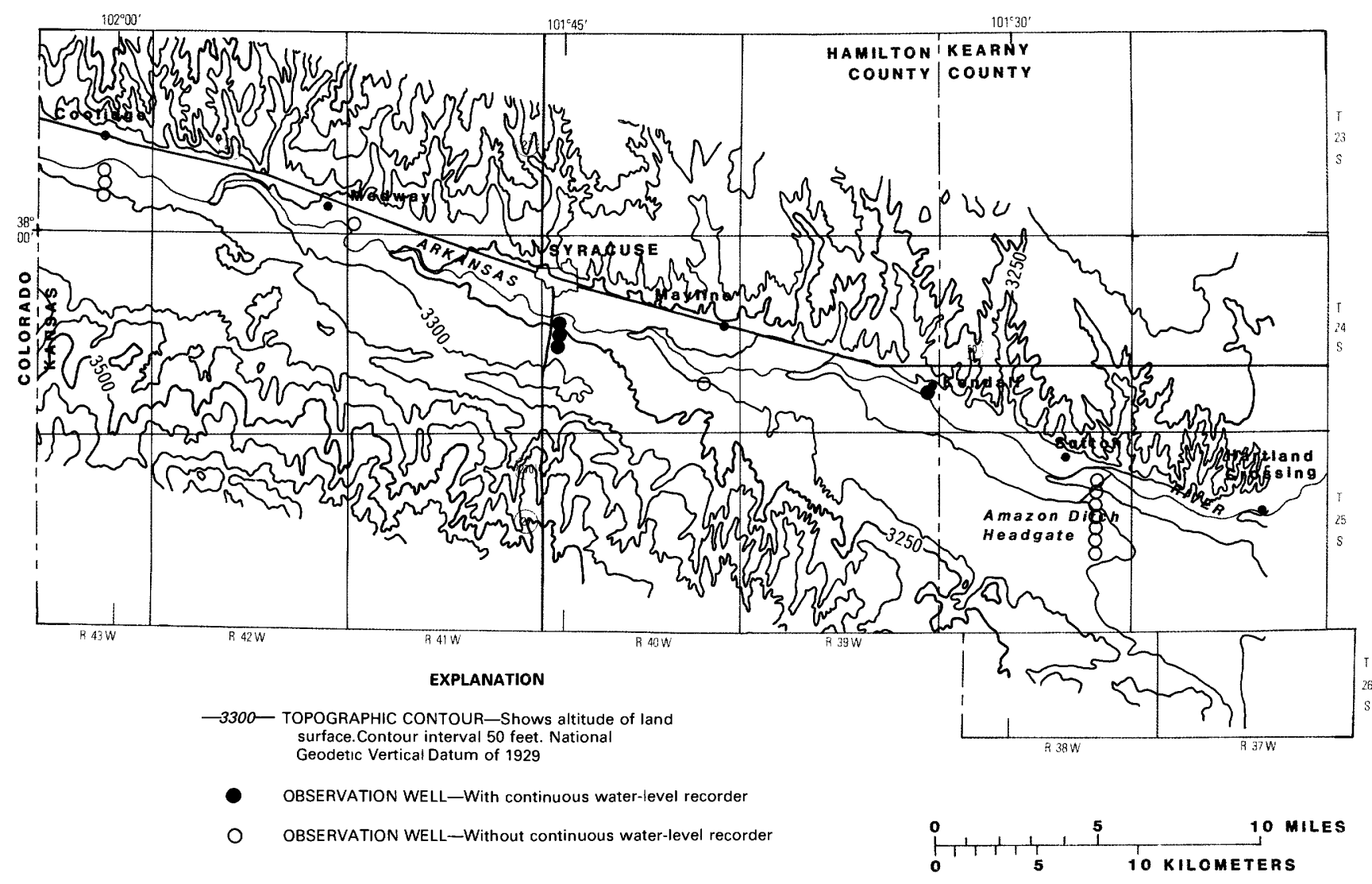

Figure 3. Topography and location of sites for monitoring ground-water and surface-water relationships.

were measured manually on a monthly (or more frequent) basis. River stages were measured monthly by wireweight gages at sites near Coolidge, Syracuse, and Kendall and by staff gages at all other sites. These specially designed observation stations on the banks of the river were used to monitor the hydraulic-head differential between river stage (or riverbed, if dry) and the water table. These data were used to evaluate aquifer response to streamflow and well pumping and to compute hydraulic properties of the aquifer.

\section{Well-Numbering System}

The well-numbering system used in this report (fig. 4) gives the location of the well or test hole according to the U.S. Bureau of Land Management's system of land subdivision. In this system, the first set of digits of a well number indicates the township; the second set, the range east or west of the Sixth Principal Meridian; and the third set, the section. The first letter after the section number denotes the quarter section or 160 -acre tract; the second, the quarter, quarter section or 40-acre tract; and the third, quarter, quarter, quarter section or 10 -acre tract. The 160-acre tract, the 40 -acre tract, and the 10-acre tract are designated A, B, C, and D in a counterclockwise manner, beginning in the northeast quadrant. Where two or more wells are located in a 10-acre tract, consecutive numbers are added in the order in which the wells were inventoried. Thus, a well numbered 24-39W-35CBA indicates that the well is in the $\mathrm{NE}^{1 / 4} \mathrm{NW}^{1 / 4} \mathrm{SW}^{1 / 4}$, sec. $35, \mathrm{~T}$. 24 S., R. 39 W.

\section{Acknowledgments}

The cooperation, services, and advice of many people helped to achieve the objectives of the study. Especially appreciated is the access granted by farmers and others to property and wells in the study area for the measurement of water levels and the collection of other geohydrologic data.

Howard Corrigan and the staff of the Division of Water Resources, Kansas State Board of Agriculture, office in Garden City, Kans., provided timely water-right, surface-water-diversion, well-discharge, and water-level data. James G. Thomas of the Kansas State University Extension office in Garden City, Kans., provided advice and records on consumptive use, soil-moisture holding capacity, and infiltration potential. William P. Hanzlick of the Kansas Fish and Game Commission office in Dodge City, Kans., provided the color infrared photography of the Arkansas River bottomland. Gordon E. Tempro, 


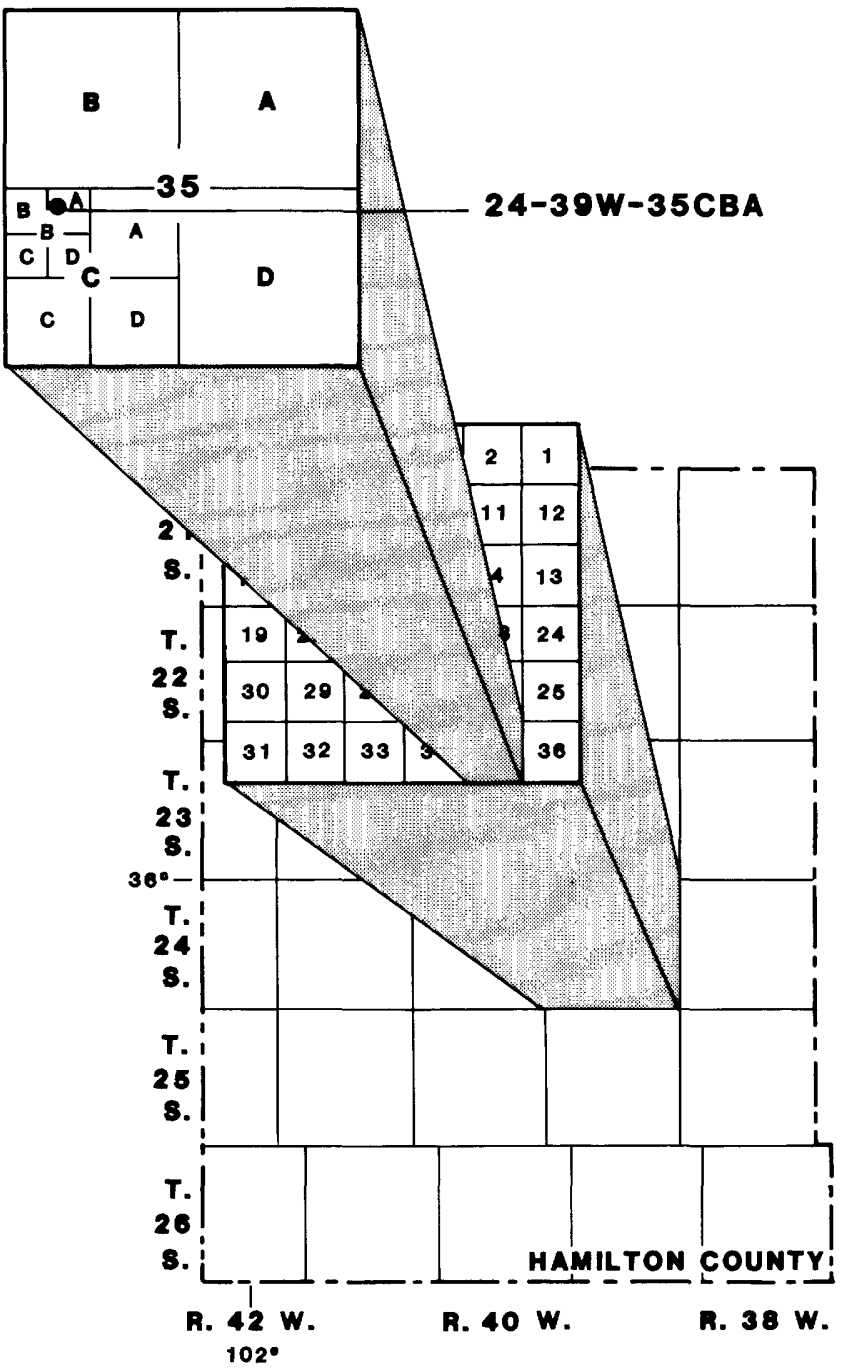

Figure 4. Well-numbering system.

Wheatland Electric (Scott City, Kans.), and M. R. Gile, Amoco Production Company (Liberal, Kans.), provided comprehensive energy-use data-without which the reconstruction of the pumpage history for the area would have been virtualy impossible. Edward A. Martinko, James W.
Merchant, and Martha J. Eager of the University of Kansas Applied Remote Sensing Program provided the study with a detailed map (modified for plate 1) of land use and vegetal cover along the Arkansas River.

James V. Tracy, formerly of the U.S. Geological Survey's ground-water modeling research staff in Reston, Va., gave support and consultation on the use of the finiteelement model.

\section{ENVIRONMENTAL SETTING}

The environmental setting of an area includes the geohydrology, climate, land use, and the associated interrelationships with the hydrologic cycle. A representation of the environmental setting of the study area is given in figure 5 .

\section{Geohydrology}

Knowing the geologic composition and structure of the study area is a prerequisite to understanding the waterbearing and water-yielding properties of the modeled stream-aquifer system. This part of the report discusses the geologic framework, the ground- and surface-water hydrology, and their interaction of ground and surface water in the study area.

The geohydrology of the study area is dominated by a northwest-to-southeastwardly trending bedrock trough partly filled with alluvium, on top of which meanders the Arkansas River. The bedrock is composed of limestone, shale, and sandstone of Cretacoues age. The bedrock is exposed at land surface, for the most part, along the northern edge of the alluvial-filled trough. The floor of the bedrock trough is uneven-characterized by a fork south of Syracuse in the deepest part of the buried channel, with an elongated bedrock high between that area and the State line (fig. 6). Relative to the overlying alluvium, the bedrock is considered to be impermeable and unable to store or yield significant amounts of water.

The southern edge of the trough is buried beneath sand dunes of Pleistocene age. The dune sand occurs as a hummocky mantle over the southern one-half of the model area. The sand is unsaturated and is generally stablized by deeply rooted vegetation. In some areas, however, these "sand hills" become active during prolonged periods of drought.

The alluvial valley fill consists mostly of wellsorted coarse sand and gravel of Pleistocene and Holocene age. These deposits range in thickness from 0 to 125 feet, and saturated thickness of the aquifer ranges from 0 to nearly 100 feet (fig. 7). Depths to the water table range from less than 1 to more than 75 feet (fig. 8). The alluvium is extremely permeable almost everywhere and is in good hydraulic connection with the Arkansas River. 


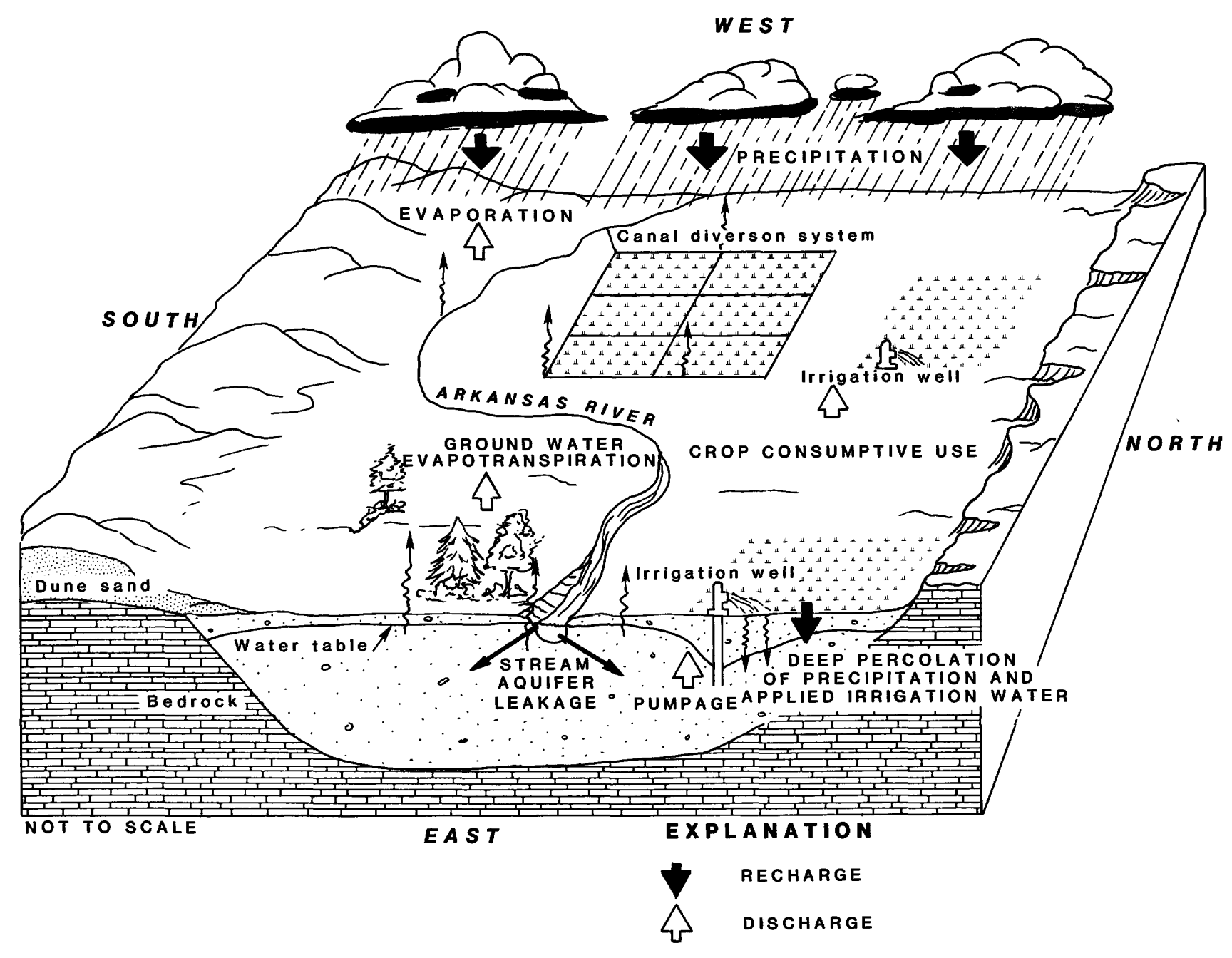

Figure 5. Schematic diagram of the relationships among geologic, hydrologic, and climatic processes.

The eastern edge of the study area abuts the Bear Creek Fault zone (fig. 1). This structure is referenced herein as a "zone" because it is difficult to locate exactly where the hydrologic effects owing to the fault begin and end. Although from west to east across the zone there is a difference in saturated thickness of more than 200 feet, it is virtually impossible to map with confidence the saturated thickness within the zone. About 5-miles wide, the zone is characterized at depth by a heterogeneous mixture of rock types and textures. Resting on bedrock in the modeled area, the Arkansas River alluvium extends eastward over the fault zone and overlies a layered section of deep alluvial deposits east of the fault zone. Below the Arkansas River alluvium east of the fault, the unconsolidated section is characterized by intertonguing beds of poorly sorted clay, silt, and sand of undifferentiated Pleistocene and the Ogallala Formation of Miocene age.
The fault generally is believed to have been caused by the dissolution of salt evaporites from the bedrock by ground water, which led eventually to structural collapse and vertical displcaement along joints and other areas of weakness. Such a cause would help explain the complex nature of the physical characteristics of the zone.

For the purpose of the model and this report, the alluvial material west of the fault is considered as a single aquifer unit that, in combination with the river, comprises the modeled stream-aquifer system. The alluvial fill is referenced henceforth as the "Arkansas River alluvium."

For the purpose of this report and the associated model, the Bear Creek Fault zone serves only to separate sections of an aquifer system. The upstream section is a relatively shallow and narrow system of the modeled Arkansas River alluvium (whose hydrology is dominated by horizontal intra-aquifer flow and vertical interaction 

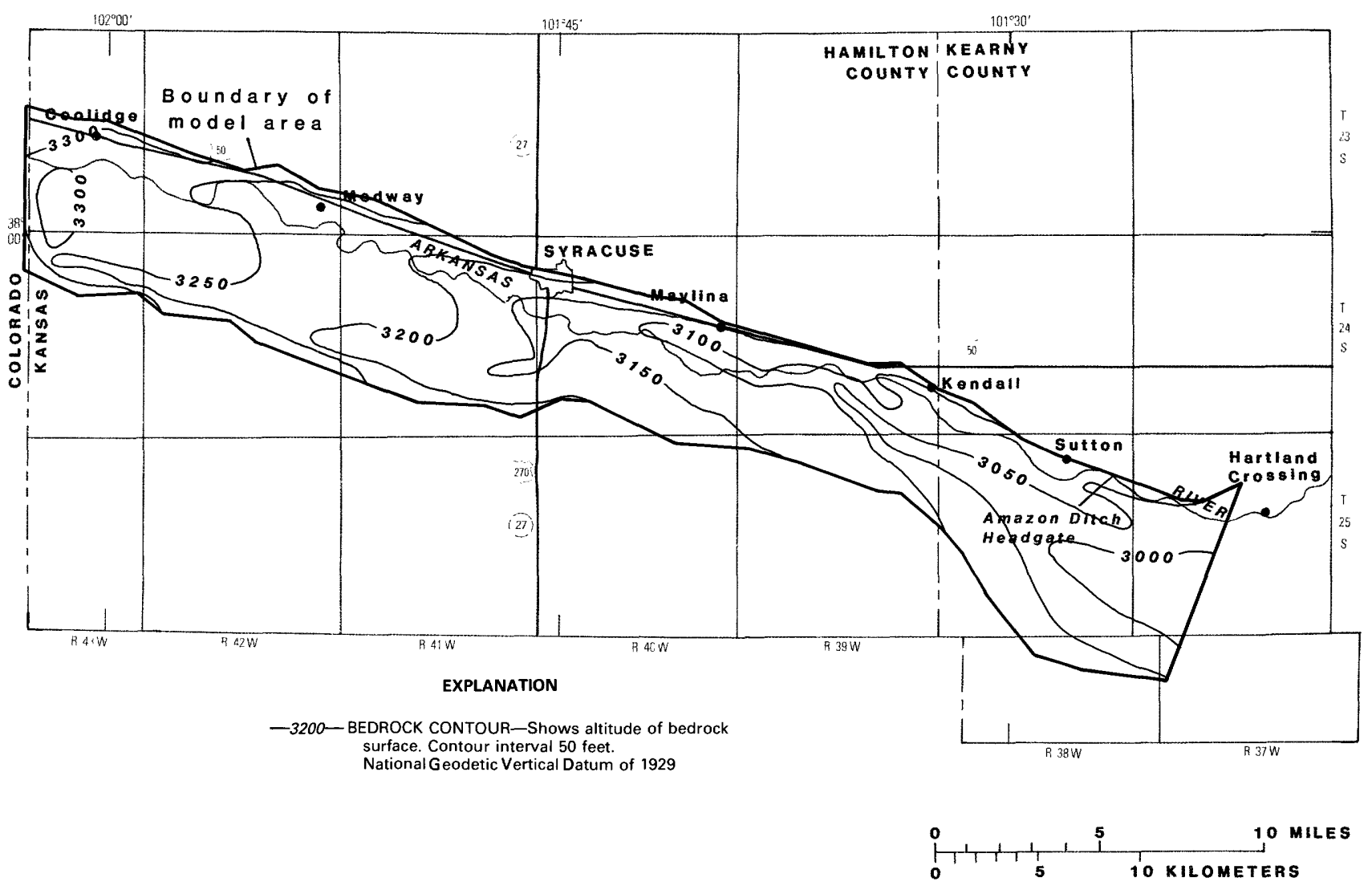

Figure 6. Configuration of bedrock surface within model area.

with the river). The downstream section is characterized by a multilayered aquifer system having significant components of vertical flow among the layers and limited interaction with surface water.

\section{Ground Water}

Water enters the aquifer by: (1) Inflow from Colorado (between bedrock highs northwest and southwest of Coolidge), (2) infiltration, or deep percolation of precipitation and irrigation water, and (3) leakage from the river. Within the aquifer, water generally flows southeastward under a hydraulic gradient averaging about $8 \mathrm{ft} / \mathrm{mi}$, as indicated by the water-level contours in figure 8 . Water discharges from the aquifer by four principal means: (1) Outflow to the Bear Creek Fault zone, (2) evapotranspiration from shallow water-table areas, called ground-water evapotranspiration, (3) leakage to the river, and (4) well pumpage.

Owing to the coarseness and sorting of the Arkansas River alluvium, wells within the study area commonly yield more than $1,000 \mathrm{gal} / \mathrm{min}$. In areas of limited saturated thickness ( 25 feet or less), well yields are typically $100-500 \mathrm{gal} / \mathrm{min}$. Under the best conditions, as much as 3,000 gal/min may be obtained. During 1979, 157 irrigation and 3 public-supply wells combined to pump nearly 65,000 acre-ft from the Arkansas River alluvium.

\section{Surface Water}

The Arkansas River channel in the study area is about 48 miles long. Bank-to-bank channel widths average less than 100 feet. Channel gradients average about 6 feet per river mile between Coolidge and Hartland Crossing.

For more than a century, irrigators in Kansas have depended upon the Arkansas River for delivery of surface water originating in Colorado. Since 1946, the delivery has been controlled by the operation of John Martin Reservoir near Lamar, Colo. John Martin Reservoir is about 50 miles upstream from the State line and was built with the purpose of controlling floods and contributing to the development of water resources within the Arkansas River basin. The reservoir was intended to supply water to irrigated lands as far downstream as Garden City, Kans.

Reservoir operation and downstream delivery is regulated through the Arkansas River Compact Administration. Delivery to the Colorado-Kansas State line during periods of request by Kansas is mandated by the Compact Administration. As defined by the Compact, stateline flow is the sum of Arkansas River discharge gaged near Coolidge and that water diverted from the river in Colorado via the Frontier Ditch for use in Kansas.

In addition to carrying water released from John Martin Reservoir, the river historically sustained its flow by gaining water from tributaries, areas of high water 


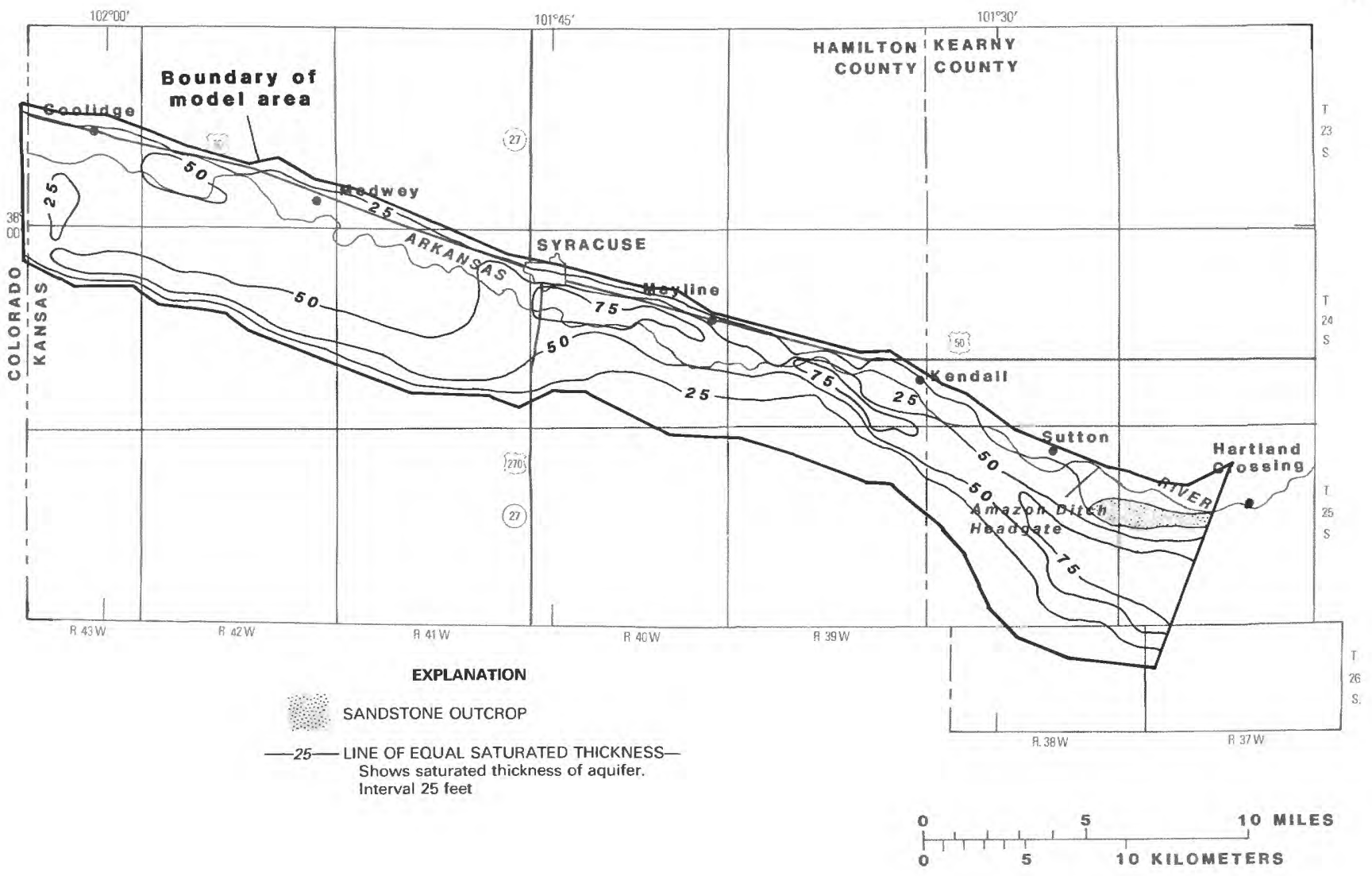

Figure 7. Saturated thickness of Arkansas River alluvium within model area, 1979.

table, and runoff from the land surface. Although previously a perennial stream, reaches downstream from Kendall have been dry most of the year since about 1975 .

Three canal systems presently (1980) divert water from the Arkansas River and affect the hydrology of the study area (fig. 9). During 1970-79, an average 9,100 acre-ft/yr was diverted into Frontier Ditch just west of the Colorado-Kansas State line for delivery in Kansas. The Amazon and Great Eastern Ditch systems together have been used to divert an average 20,000 acre-ft/yr since 1970 through the Amazon Ditch headgates for irrigation in Kearny County east of the model area. Diversions via the Southside Ditch, also used east of the model area, have averaged about 6,000 acre-ft/yr since 1970. Originally, there were two additional diversion canals, the Alamo and the Fort Aubrey Ditches; however, they have not been used to divert water since the late 1960 's, owing to insufficient supply and legal problems.

\section{Ground- and Surface-Water Relationships}

Interaction between the stream and aquifer greatly affects the distribution of water in the study area. Ground water typically travels less than $0.1 \mathrm{ft} / \mathrm{d}$, whereas surface water typically flows at a rate of 1 to $10 \mathrm{ft} / \mathrm{s}$. Thus, the effect of abrupt or short-term change in the water supply generally is indicated first in the river and is transferred in time to the aquifer. Examples of relatively abrupt effects include those resulting from changes in the rates of precipitation, diversion, tributary flow, and reservoir releases. Changes in the water supply that occur gradually, such as those resulting from long- term changes in the rates of pumping or infiltration, commonly are detected first in the aquifer and show up later as reduced or increased streamflow.

The exchange of water between the stream and aquifer (called stream-aquifer flux) is buffered by an intervening medium, called the streambed. The rate and direction of flux through the streambed depends on the hydraulic conductivity of this interface and the hydraulic gradient between the stream and water table. Where the streambed hydraulic conductivity is relatively uniform, such as along the Arkansas River, differences in stream-aquifer flux are controlled mostly by local differences in the gradient. Water flows with the gradient, from areas of relatively high to relatively low hydraulic head. A stream that loses water to the aquifer is called a losing stream. By contrast, a gaining stream receives in flow from the aquifer.

The distribution of water in a stream-aquifer system undergoing development can change if the development causes prolonged or permanent changes in the direction or the magnitude of the stream-aquifer gradient. The evolution of stream-aquifer conditions when well develop- 


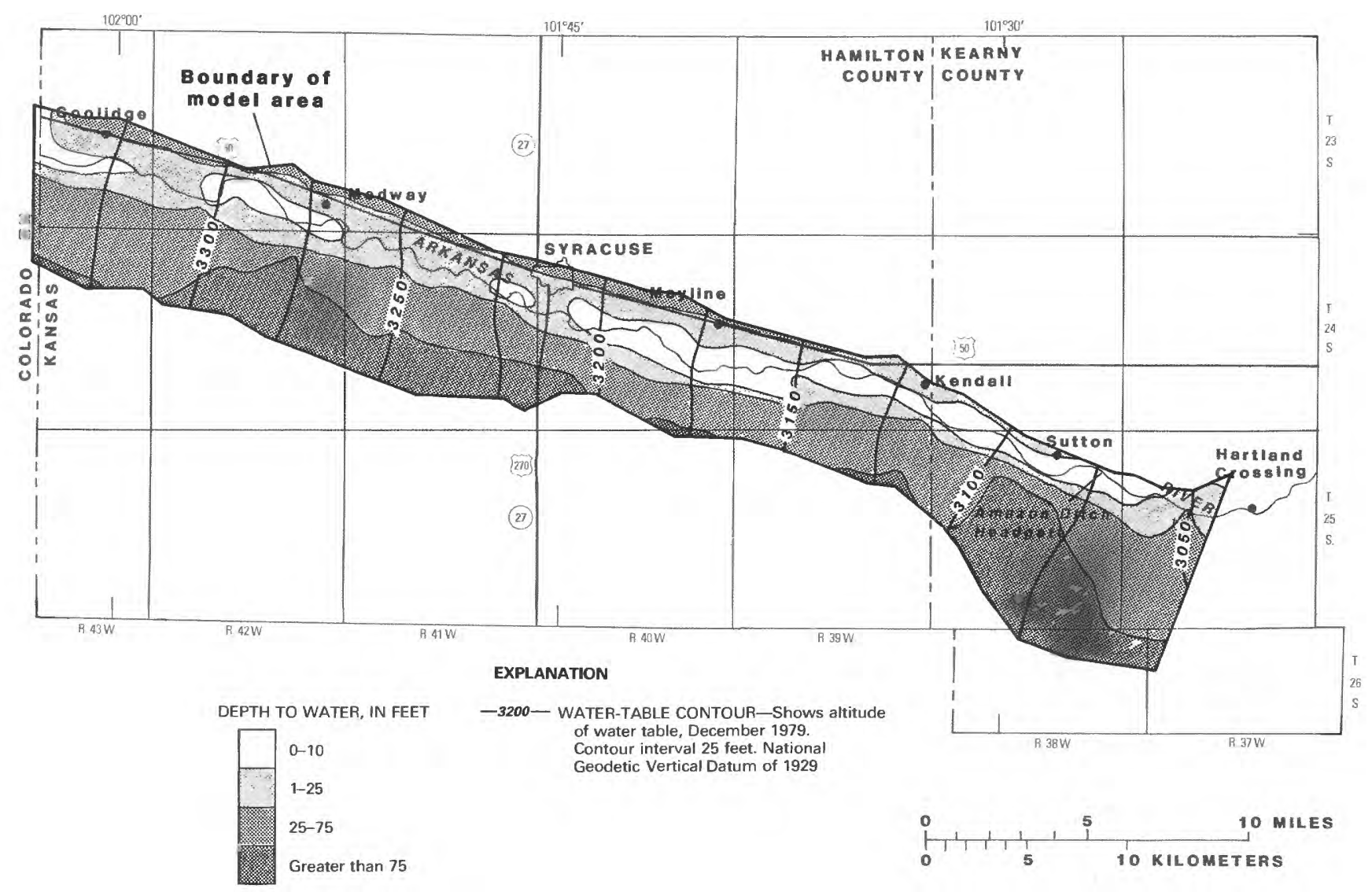

Figure 8. Depth to water table and water-table contours within model area, December 1979.

ment exceeds the natural capacity of the system is illustrated schematically in figure 10 . Typical predevelopment conditions are depicted in figure 10A. Except for times of temporarily high stage (due perhaps to spring runoff), the hydraulic gradient slopes from the aquifer toward the stream. Inflow to the stream under such conditions of equilibrium is called base flow. After moderate development, the gradient may fluctuate in direction on a seasonal basis (fig. 10B). The water table is below stream level at a short distance from the stream during the summer due to well-field drawdown and increased tributary streamflow. Constrastingly, the water table recovers during the winter due to well shutdown, and the stream once again gains base flow from the aquifer. The extreme situation occurs when the water table has declined below the streambed (fig. 10C), and streamflow has either ceased altogether or is intermittent. Here, unsaturated material occurs between the streambed and the water table. As the water table is now below the streambed, the stream loses year around, during any condition of flow.

The reduction or stoppage of streamflow as a result of ground-water development is called stream depletion. As defined, stream depletion includes both: (1) Flow in- duced directly from the stream channel and (2) flow enroute to the stream channel that is intercepted as a result of the pumping. A relatively simple, yet practical method for evaluating stream depletion was described by Jenkins (1970).

Jenkins' method computes the rate and volume of stream depletion as a function of: (1) The distance of the pumping well from the stream, (2) the rate of pumping, (3) the time of pumping, (4) the storage coefficient, and (5) the transmissivity of the aquifer. Transmissivity is equal to the product of aquifer hydraulic conductivity and saturated thickness. For the purpose of evaluating stream depletion, storage coefficient is considered equal to the specific yield (ratio of the volume of water that the saturated material will yield by gravity drainage to the volume of the material). Jenkins's stream-depletion method has been used to establish guidelines for the conjunctive use of ground and surface water along the Arkansas River in Colorado (Jenkins and Taylor, 1972; Taylor and Luckey, 1974).

Equations derived by Jenkins (1970) were used to compile graphs, shown in figure 11 , that provide a general basis for predicting the relative effects of stream depletion 


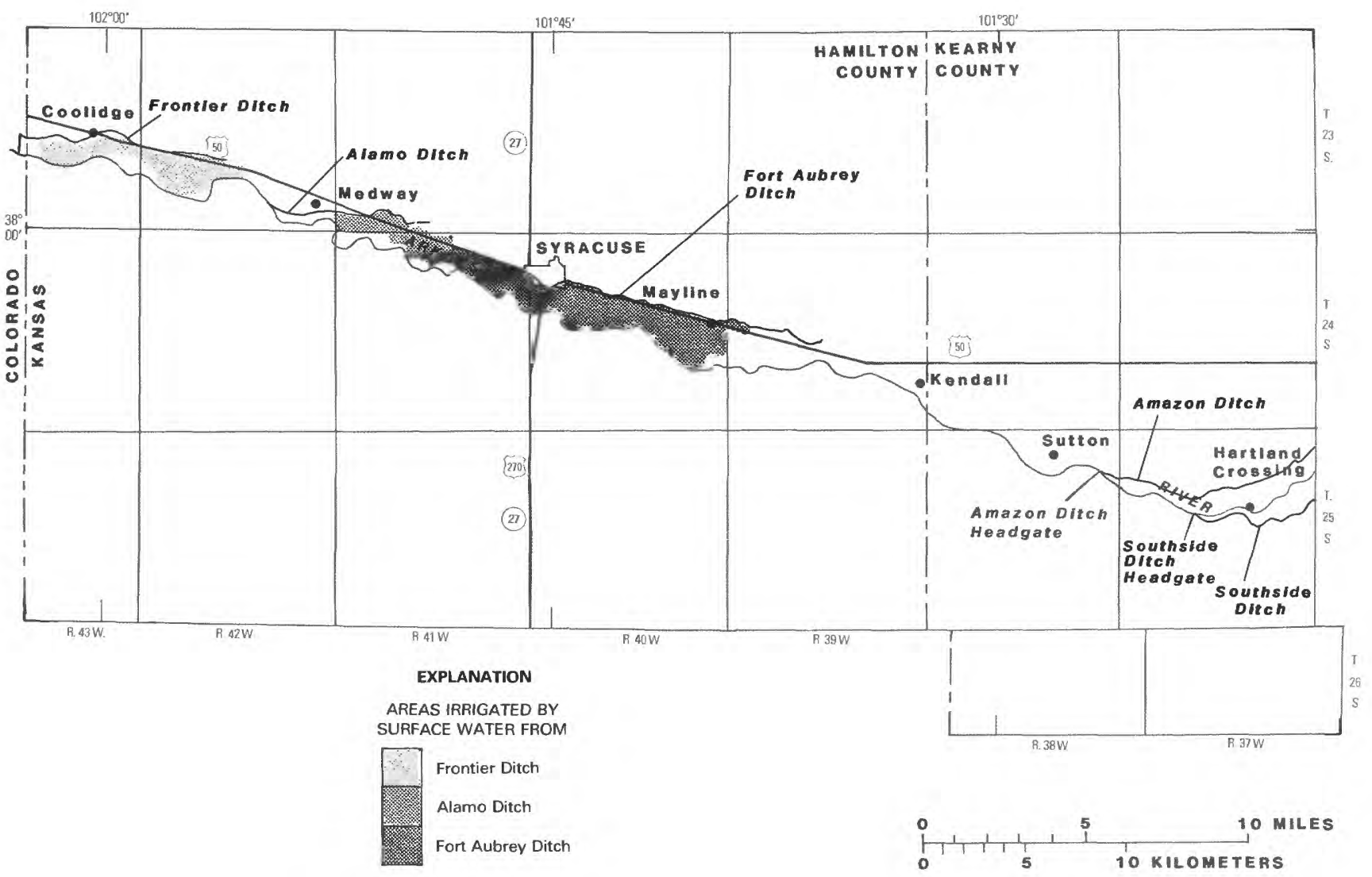

Figure 9. Ditch diversions, areas of ditch irrigation, and drainage system.

along the Arkansas River in Kansas. These illustrations show the expected effect of distance and time on the minimum and maximum conditions of stream depletion, considering the average value of specific yield and the range in transmissivity found by model calibration. Stream depletion is shown as a function of distance at the top of figure 11 and as a function of time at the bottom of figure 11.

Both graphs result from assuming a storage coefficient of 0.17 , the average value of specific yield used in the calibrated model of the stream-aquifer system. The upper curve in each graph shows the magnitude of stream depletion, assuming a transmissivity of $80,000 \mathrm{ft}^{2} / \mathrm{d}$, or $800 \mathrm{ft} / \mathrm{d}$ (model value of hydraulic conductivity) times the maximum saturated thickness of 100 feet (fig. 7). The lower curve shows the magnitude of depletion by assuming the transmissivity to be $8,000 \mathrm{ft}^{2} / \mathrm{d}$ (or $800 \mathrm{ft} / \mathrm{d} \times 10$ feet), the effective lower limit of transmissivity in the study area. Stream depletion is expressed in the graphs as a percentage representing the cumulative volume of depletion divided by the cumulative volume of well discharge, times 100 .
Use of the Jenkins' stream-depletion method requires that certain generalizations be made about the geohydrologic system. The most important of these generalizations are as follows:

(1) There is continuous streamflow in the stream channel;

(2) the stream and aquifer are hydraulically connected;

(3) the aquifer is isotropic, homogeneous, and semi-infinite in areal extent;

(4) the stream fully penetrates the aquifer;

(5) the well is open to the full saturated thickness of the aquifer;

(6) the well discharge is steady; and

(7) drawdown is negligible when compared to saturated thickness; that is, transmissivity does not change with time.

In the case of assumption (1) not being satisfied, the graphs serve only to indicate the potential for stream depletion. Two significant conditions not accounted for in the graphs include the partial sealing of the streambed 
A

Predevelopment

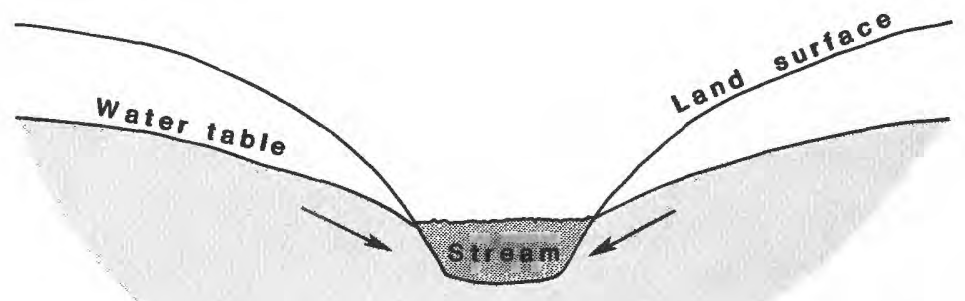

Aquifer

B

Moderate development

SUMMER
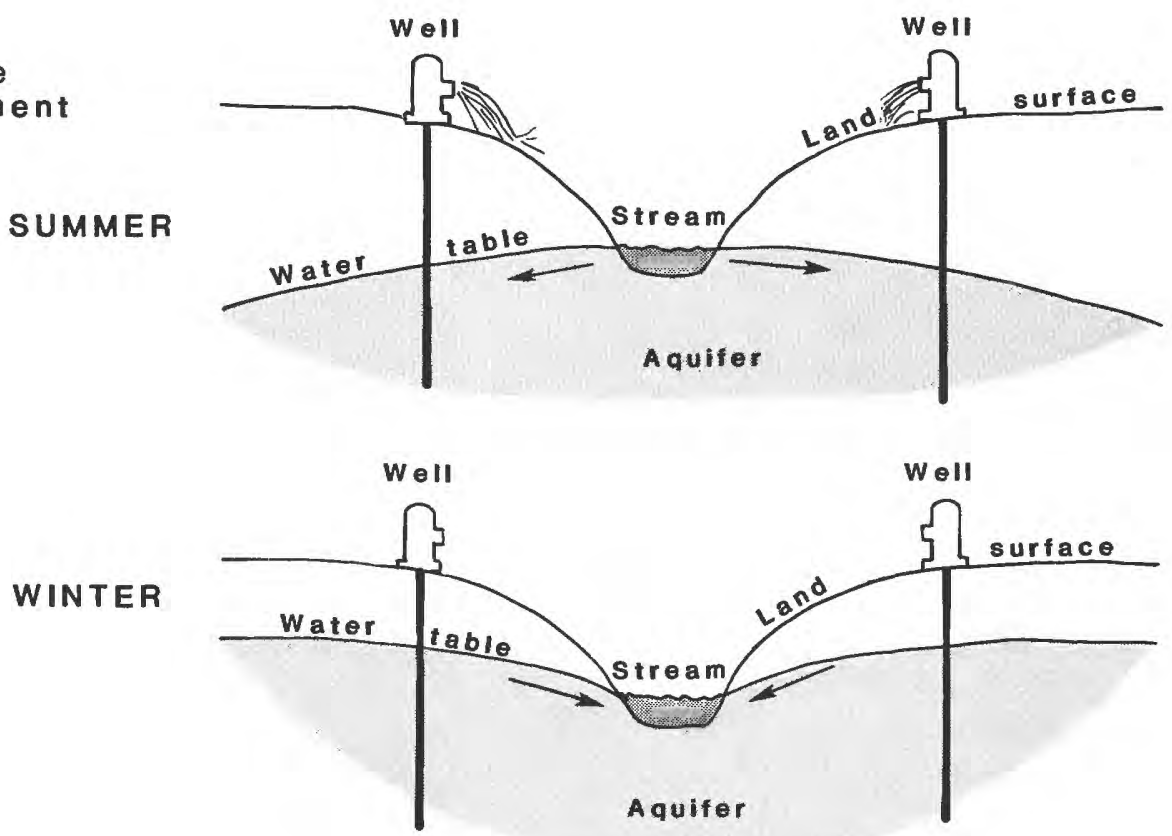

C

Heavy

development

\section{EXPLANATION}

$\rightarrow$ Generalized direction of ground-water movement

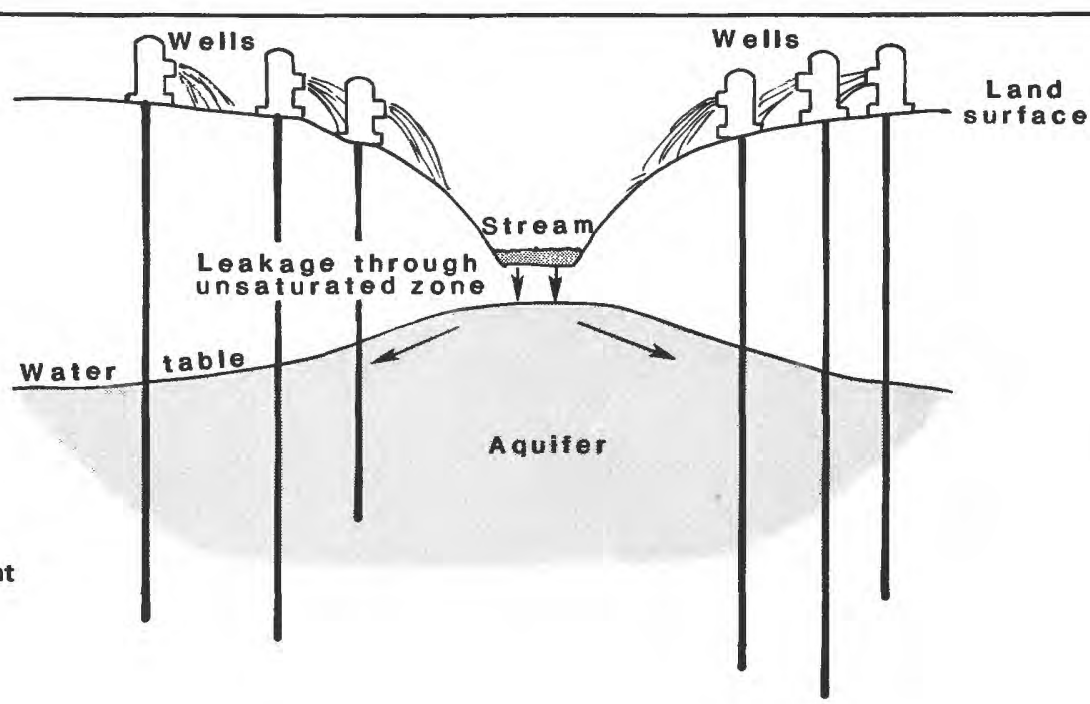

Figure 10. Evolution of a typical stream-aquifer system's response to well development. 


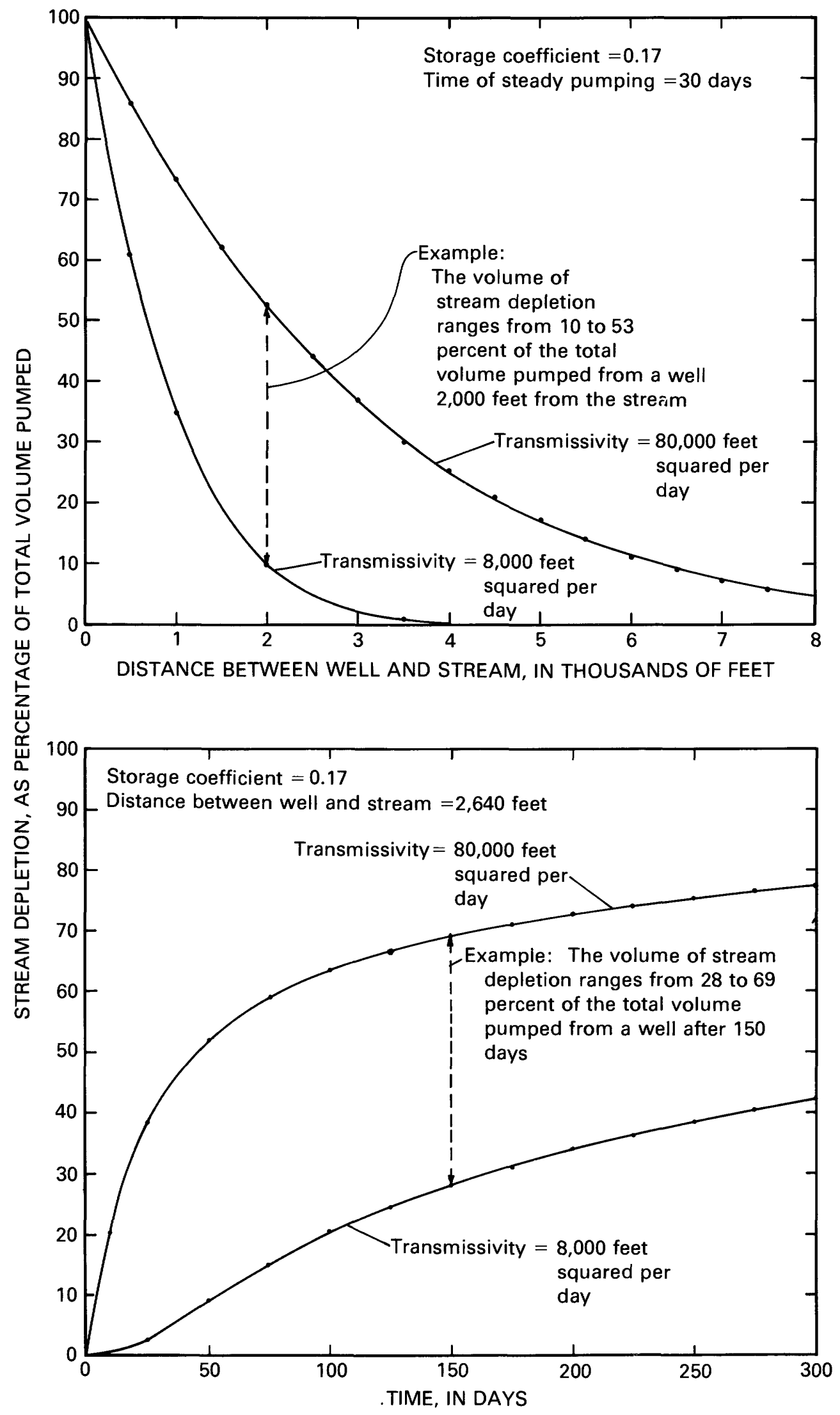

Figure 11. Stream depletion as a function of distance and time. 
during low-flow periods and the areal decrease in saturated thickness owing to prolonged or heavy pumping. Because the result of these prominent occurrences is to reduce both the stream-aquifer interconnection and aquifer transmissivity, perhaps the lower parts of the graphs better represent actual situations.

\section{Climate}

The climate of the study area is characterized by abundant sunshine, moderate precipitation, little relative humidity, brisk winds, and large rates of potential evapotranspiration. The summers are generally hot and the winters, moderately cold. The average date for the last killing frost in the spring is April 27, and the average date for the first killing frost in the fall is October 14. On the average, about 75 percent of the precipitation occurs during the 170-day growing season.

Precipitation across the moratorium area ranges from about $14.5 \mathrm{in} / \mathrm{yr}$ near the Colorado-Kansas State line to about $17.5 \mathrm{in} / \mathrm{yr}$ at Lakin, Kans., about 5 miles east of the study area. The 30-year normal $(1941-70)$ precipitation at Syracuse, near the center of the modeled area, is $16.86 \mathrm{in} / \mathrm{yr}$. The long-term (1894-1979) average annual precipitation at Syracuse is 16.46 inches.

The probability distribution of 1894-1979 annual precipitation at Syracuse is shown in figure 12. The graph shows (as a percentage) the probability of receiving a minimum amount of annual precipitation. For example, there is a 75-percent probability (on the average) that annual precipitation would be at least 14 inches. The chance of 20 or more inches of annual precipitation is about 25 percent. Assuming the data are normally distributed, there should be a 50-percent probability of precipitation equaling the long-term average (16.46 inches). The plots for years 1970-79 are labeled to show the significance of that period of less than average precipitation.

Evapotranspiration or "...the total of evaporation and transpiration..." (Cruff and Thompson, 1967, p. 2) occurs in the study area mostly by water consumed by crops and native vegetation. In this report, the demand for water by plants, not limited from lack of water during growth, is called consumptive-use demand. The actual discharge of water from the land surface or soil zone as a result of the consumptive-use demand is referred to as actual evapotranspiration. When the actual evapotranspiration is less than the consumptive-use demand, the difference is referred to as evapotranspiration deficit.

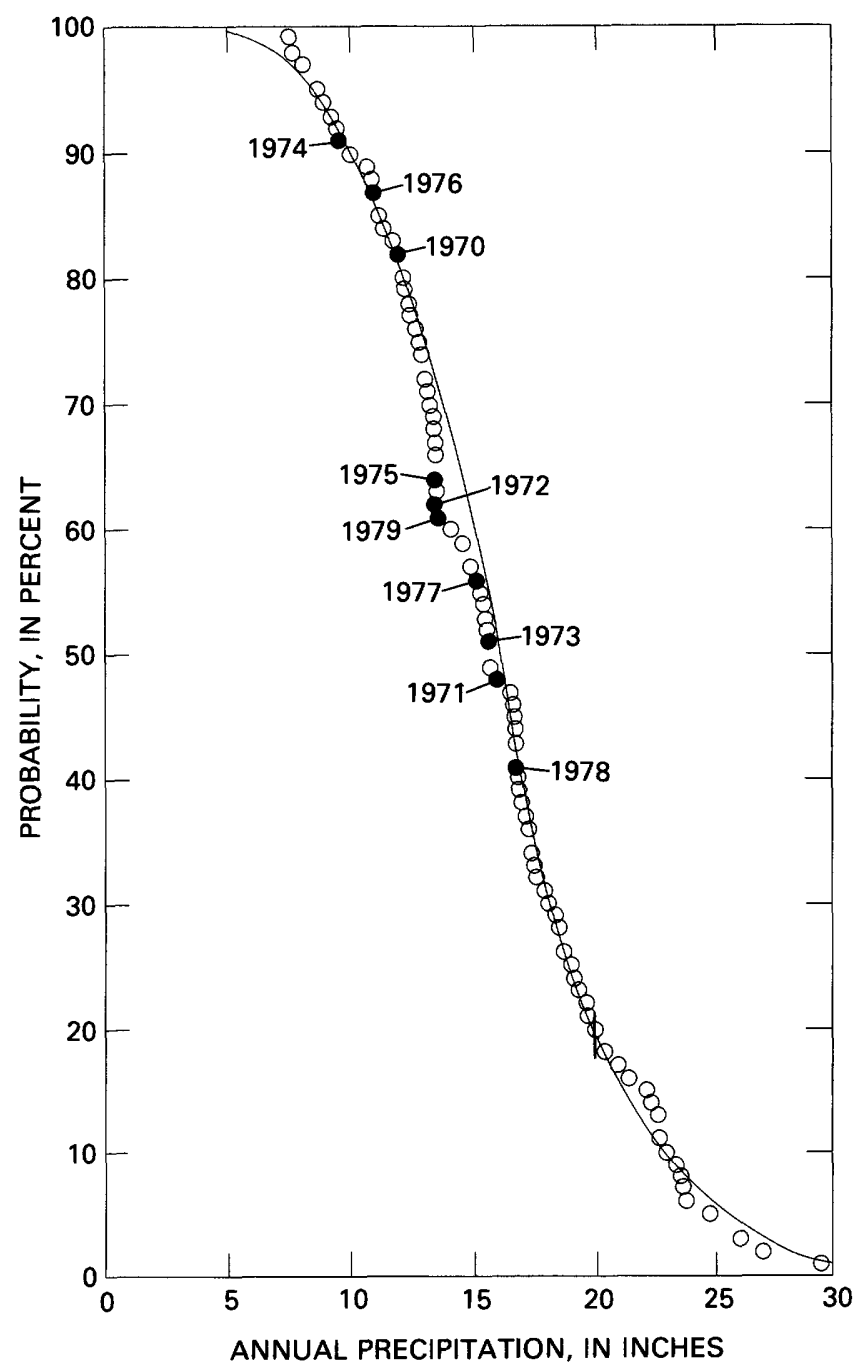

Figure 12. Probability distribution of annual precipitation at Syracuse, based on the 1894-1979 record.

Consumptive use is defined by the U.S. Department of Agriculture (1967) as “... the amount of water used by the vegetative growth of a given area in transpiration and building of plant tissue and that evaporated from adjacent soil or intercepted precipitation on the plant foliage in a specified time." The Blaney-Criddle method, as presented by the U.S. Department of Agriculture (1967), was used to compute rates of consumptive-use demand for the study. 
Consumptive-use demand, which is dependent on local climatic phenomena and crop type, was estimated for the study and model input using:

$$
U=\frac{\left(K_{t}\right)\left(K_{c}\right)(t p)}{100},
$$

where

$U=$ consumptive-use demand of crop, in inches per month;

$K_{t}=$ climatic coefficient related to mean monthly air temperature;

$K_{c}=$ a coefficient reflecting the crop's monthly growth stage;

$t=$ mean monthly air temperature, in degrees Fahrenheit; and

$p=$ monthly percentage of daylight hours during the year.

After monthly values of $K_{t}, t$, and $p$ were determined from climatological data specific to the study area, the remaining variable to be defined was $K_{c}$, which relates only to crop type and is not dependent on geographical area. Values of $K_{c}$, provided by the U.S. Department of Agriculture (1967), were used in combination with the locality-dependent data to compute monthly rates of consumptive use by the major plant types for each year between 1951-79.

The monthly rates on consumptive-use demand during 1979, as computed with the Blaney-Criddle formula, for the five principal crops and land-use categories are shown in figure 13. The rangeland demand was calculated using crop-growth stage coefficients for pasture. Areally weighted monthly means of individual consumptive-use demands also are given in figure 13. These weighted means are calculated to account for the percentage of total area occupied by each crop or land-use category and, therefore, represent area-wide demands. The area-wide composites of the individual demands are required for model simulation of actual evapotranspiration, deep percolation, and ground-water evapotranspiration (see Computer-Model Analysis).

\section{Land Use}

Land use in the study area is dominated by agriculture. The gently sloping river bottomland (fig. 3) is characterized by fertile clay and sandy loam soils, which supports most of the irrigated cropland in the area. The "sandhills" south of the river are characterized by fine,

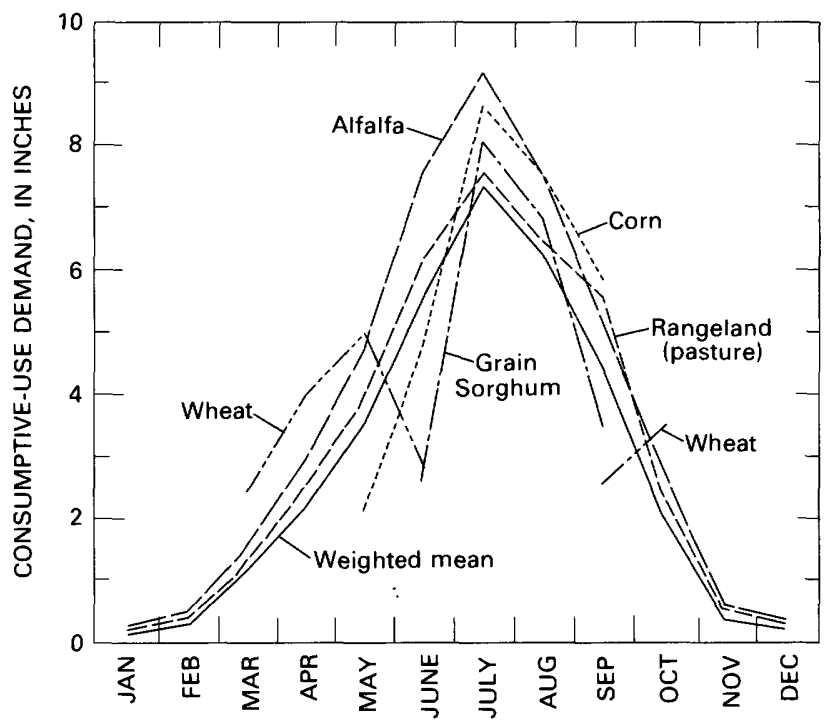

Figure 13. Rates of consumptive-use demand by predominant crops and land-use categories, 1979.

loose sand and generally are unirrigated, although some areas south of Coolidge and southeast of Kendall have been irrigated by center-pivot systems during recent years. Most upland areas north of the river are covered by thin, sandy soils. The uplands, for the most part, are not cultivated; however, limited areas support dryland farming.

Of the nearly 110,000 acres in the model area, about 31,000 were irrigated during 1979. The distribution of irrigated land, delineated for the study by the University of Kansas Applied Remote Sensing Program, is provided on plate 1. The data shown are applicable to the late 1970's and should apply through the mid-1980's. Irrigated acreage increased about 10 percent during the 1970's, as determined by comparing 1971 aerial photography with that for 1978.

Data supplied by the Hamilton and Kearny County Agricultural Stabilization and Conservation Service were used to define the type and areal distribution of crops and land use in the study area. In summary, these data show the five principal categories (and the associated percentages of total model area) to be:

(1) rangeland or non-cropped areas (56 percent);

(2) alfalfa (16 percent);

(3) grain sorghum (12 percent);

(4) corn (8 percent); and

(5) wheat ( 8 percent). 


\section{Historic Hydrologic Response}

The hydrologic system has responded historically to periods of both greater and lesser water supply. During periods when the supply exceeded demand, water levels and river discharge increased; when the supply was deficient, water levels and streamflow decreased. Scientific observations of aquifer and stream response to fluctuations in precipitation, consumptive use, pumpage, and State line streamflow have been made in the study area for more than 50 years.

Monthly precipitation and streamflow at Syracuse for 1940-79 are shown in figure 14 in addition to the associated water-level response in wells near the western and eastern margins of the model area. The corresponding water-level response in wells located between these margins is shown in figure 15. The location of the observation wells whose hydrographs are shown in figure 15 are indexed in figure 2.

Examination of figures 14 and 15 reveals important similarities among hydrologic cause and effect; extremes evident in one kind of data are mirrored by the others. The decrease in streamflow rates between 1952-56 corresponds to the same 5-year period of 34-percent less than long-term average precipitation (10.86 versus 16.46 inches) and to the prominent depression in the water-level hydrograph for well $23-43 \mathrm{~W}-21 \mathrm{ABA}$. Another example of parallel hydrologic reponse is evident in the pre- 1965 streamflow and water-level records, which relate to the 13 percent less-than-average precipitation during 1959-64. The pre-1965 low is followed by a significant increase in streamflow during 1965-66 with a corresponding recovery in the water table. During 1965, 27.2 inches of precipitation occurred at Syracuse, the second highest amount for 86 years of record (10.5 inches, or 65 percent greater than average).

Perhaps the most prominent pattern of similar hydrologic observation is that for the 1970's. During 197079, precipitation at Syracuse averaged 14 percent, or nearly 2.5 inches less than average. Only during 1978 did the precipitation exceed the 86-year average of 16.46 inches. Correspondingly, the streamflow and water-level hydrographs show a marked and continuous decline during 1970-79.

Although definite relationships among precipitation and streamflow at Syracuse and water levels in the area are indicated in figures 14 and 15 , it is difficult to separate elements of cause and effect. Certainly, less precipitation results in less water supply; however, its impact on water levels and streamflow depends on secondary factors such as the timing of the deficient precipitation in terms of

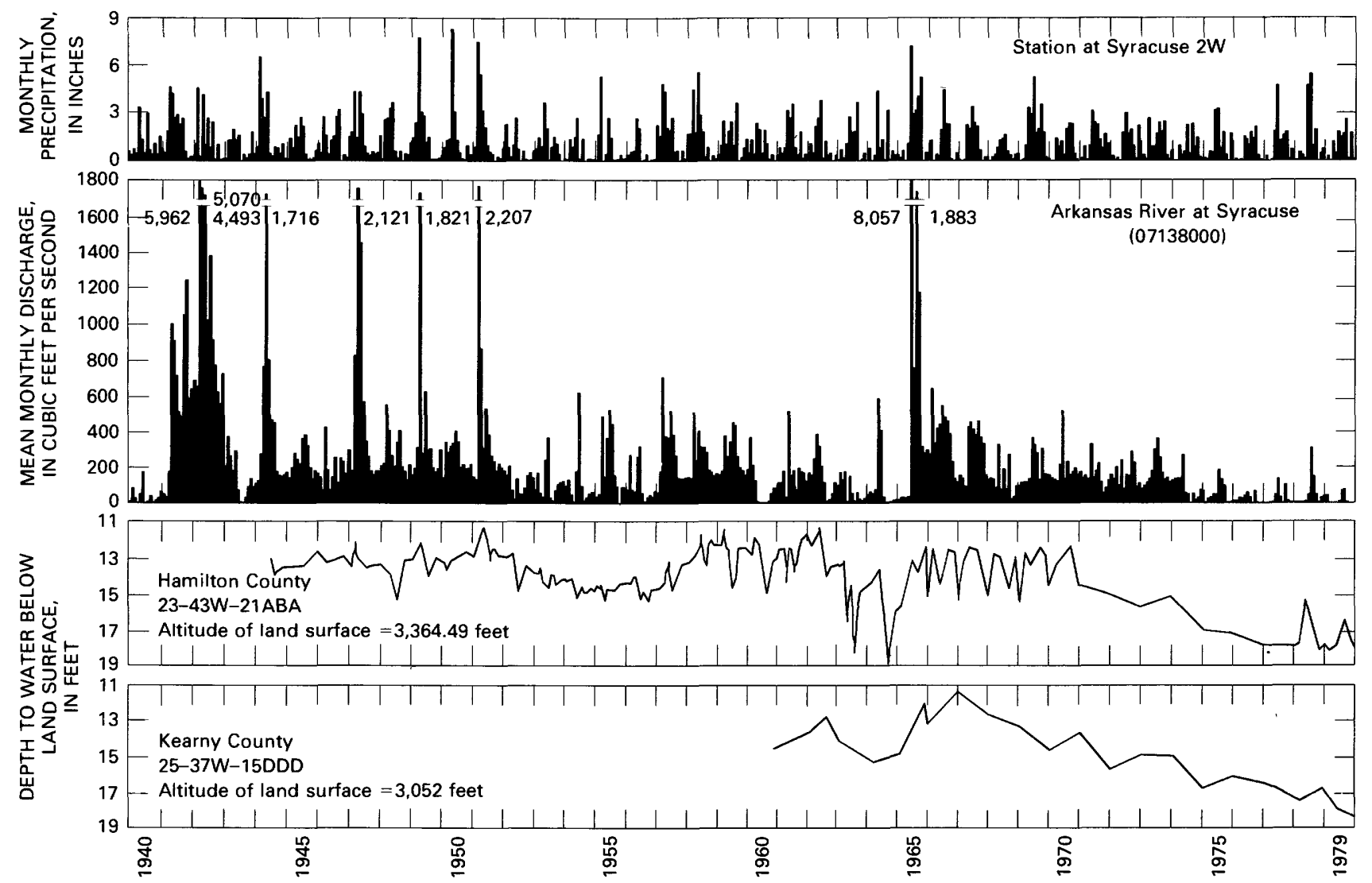

Figure 14. Relationship among precipitation, streamflow, and ground-water levels at selected sites, 1940-79. 

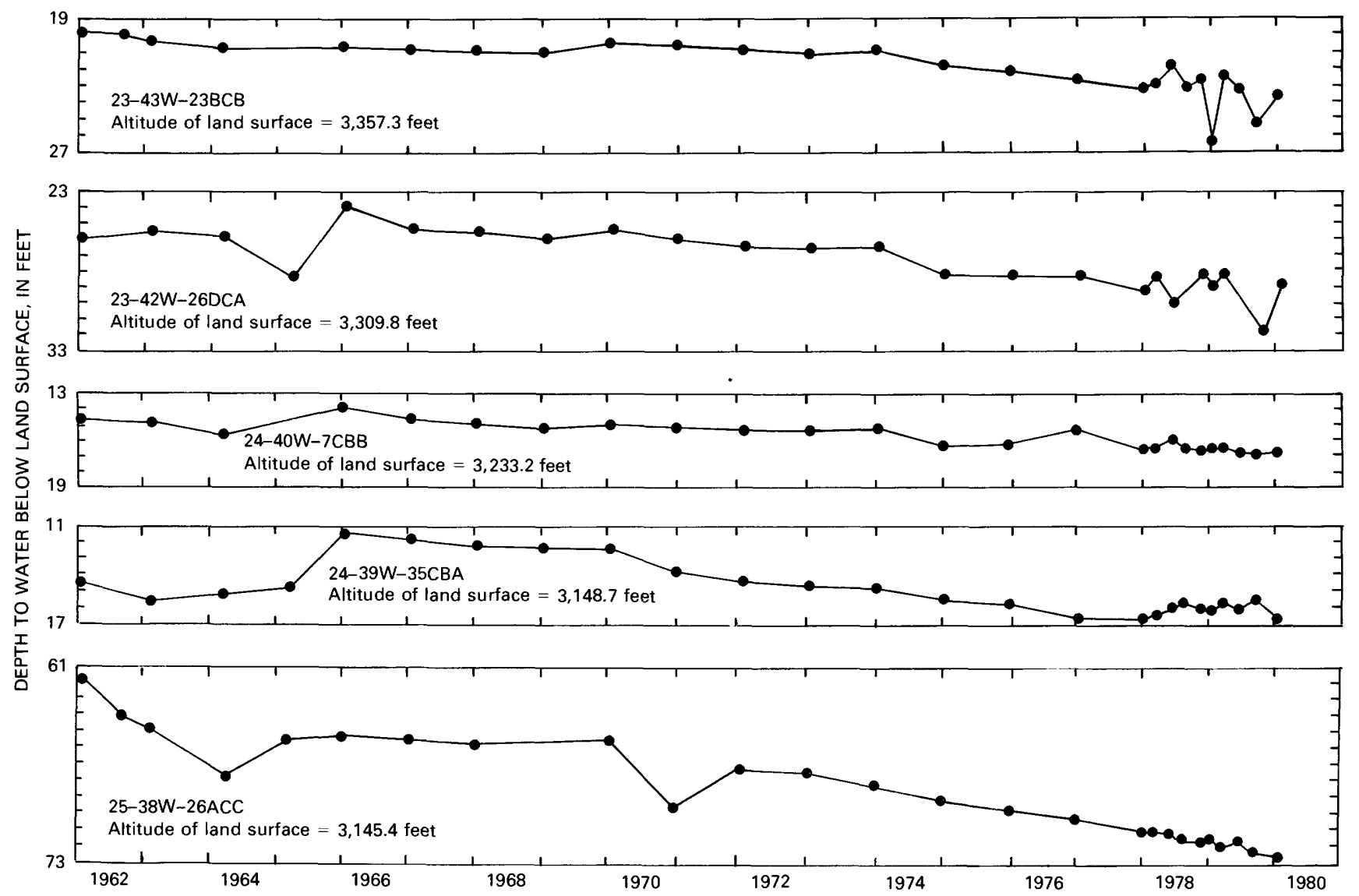

Figure 15. Water-level fluctuations at selected sites, 1962-79.

crop needs. Deficient precipitation during the fall and winter months probably does not affect the water levels and streamflow as much as a comparable deficiency in June, July, or August-during the growing season-when consumptive-use rates are peaking. To compensate for deficient rainfall during the growing season, irrigators need to divert more river water and pump wells longer. This action increases water-level decline and streamflow loss, to a greater extent than results from receiving less recharge owing to less precipitation.

Water-level response is related to the flow of the Arkansas River at Syracuse, as indicated in figure 14, River flow at Syracuse, as in all downstream reaches, is a product of incoming streamflow to the study area across the State line. This incoming river flow decreased 60 percent, from an average $232 \mathrm{ft}^{3} / \mathrm{s}$ (between 1951-69) to $85 \mathrm{ft}^{3} / \mathrm{s}$ (between 1970-79), as shown in figure 16 . The seasonal significance of this decrease is shown in figure 17. The greatest differences between the 1951-69 and 1970-79 average monthly rates occurred between May and September, the time of the year when the water is needed most by downstream irrigators along the Amazon, Great Eastern, and Southside Ditches.
In addition to the river inflow (gaged just downstream from the State line near Coolidge), water is diverted for Kansas just upstream from the State line via the Frontier Ditch (fig. 9). The rates of diversion in Frontier Ditch also were reduced during the 1970's, with an almost year-to-year decrease since 1971 (fig. 18). Between 1951-69, diversions in Frontier Ditch averaged 9,700 acre-ft/yr, compared to an average of $9,100 \mathrm{acre}-\mathrm{ft} / \mathrm{yr}$ between 1970-79, Diversions via downstream ditch systems have decreased to a greater extent because of diminishing upstream flow.

The relationship between stream stage and aquifer water levels has changed during the 1970's in response to decreased recharge (precipitation and State line streamflow) and to increased discharge (pumpage and consumptive use). Although stream stages have declined significantly, the water table has declined to the extent that during most of the year it is below the stream stage in most parts of the study area. Manifestation of this change in the stream-aquifer gradient has been the progression from a generally gaining reach between Coolidge and Syracuse to one that is now (1980) predominantly losing. 


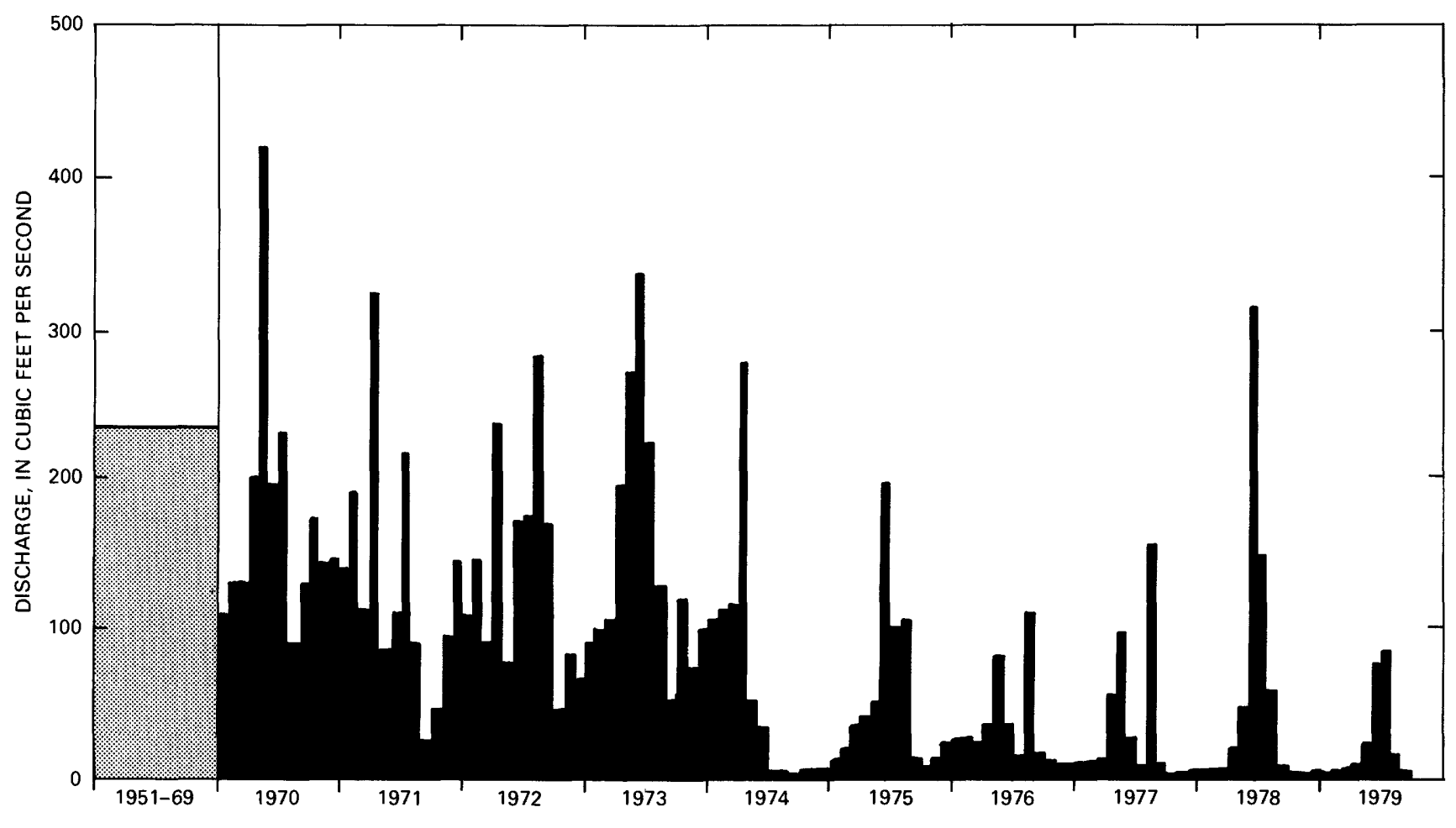

Figure 16. Monthly discharge of Arkansas River near Coolidge, 1951-69 and 1970-79.

An analysis of gains and losses in the Arkansas River between Coolidge and Syracuse was made with historical streamflow and canal diversion and return records. As shown in figure 19, these data indicate no net annual loss between Coolidge and Syracuse prior to 1965. The net stream gain during 1951-64 averaged about $15 \mathrm{ft}^{3} / \mathrm{s}$, or nearly 10 percent of the gaged flow at Coolidge. Data for 10 of the 15 years following 1964, however, indicate net annual river losses. According to the analysis, the Arkansas River between 1965-79 lost an average of $4.4 \mathrm{ft}^{3} / \mathrm{s}$ or 8 percent of its flow between Coolidge and Syracuse, a distance of about 20 river miles.

The time distribution of these river losses is consistent with the trend of declining water levels in the area. The change in the gain-loss relationship between Coolidge and Syracuse is interpreted to have occurred in response to the water-level decline. Historically, the prevailing hydraulic-head gradient sloped from the aquifer toward the stream; however, in recent years, the gradient has in places reversed in direction owing to the water-level declines adjacent to the stream channel. Consequently, the stream now loses in places and during times of the year that in the past it predominantly gained. The water-level declines, which contributed to the gradient reversal, are believed to have resulted most directly from: (1) decreasing river flow across the State line from Colorado, (2) increasing ground-water withdrawals, (3) less-than-average precipitation between 1970-79.

\section{COMPUTER-MODEL ANALYSIS}

\section{Background}

The use of digital models to aid in the analysis and management of water resources began in Kansas during the 1970's. A vital function of the Division of Water Resources, Kansas State Board of Agriculture, is the for- 


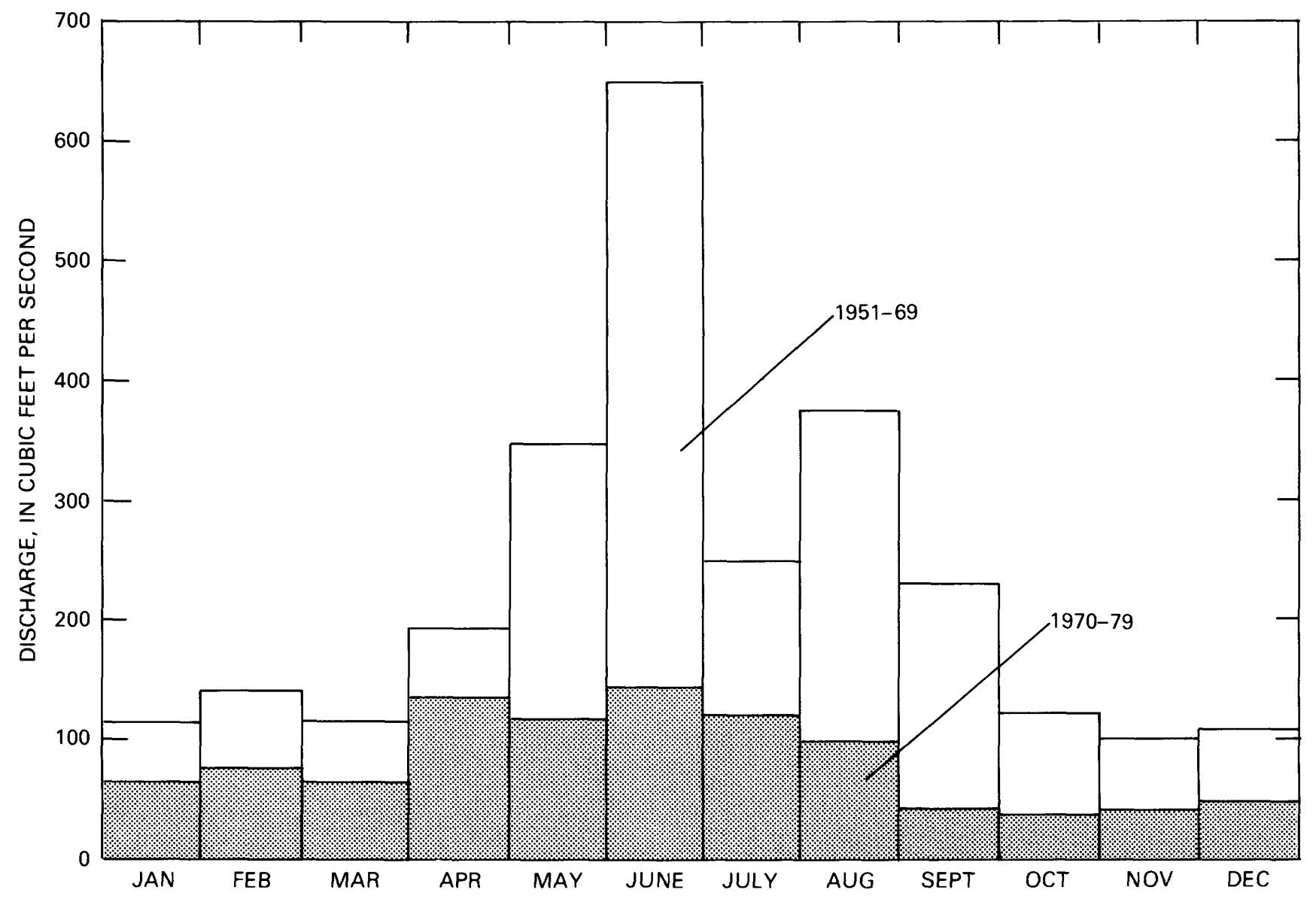

Figure 17. Mean monthly discharge of Arkansas River near Coolidge, 1951-69 and 1970-79.

mulation of regionalized guidelines for ground- and surface-water development that are in the best overall interests of satisfying the need for the water resource, while at the same time providing for its conservation. In addition to requiring an evaluation of the geohydrologic framework, this responsibility involves assessing the advantages and predicting the consequences of using the water supply. The digital model can test the effects of alternative water-development plans before they are actually enacted.

The digital model of the Arkansas River valley stream-aquifer system uses a computer program written by J. V. Tracy (U.S. Geological Survey, written commun., 1980). The Tracy finite-element model is based on the Galerkin finite-element method, described by Desai and Abel (1972), and uses the CSR (Cholesky square-root) computational method, described by Weaver (1967) to solve the nonlinear, partial-differential equation describing nonsteady, two-dimensional ground-water flow. The CSR method provides a direct solution to the sets of simultaneous equations that result from the finite-element formulation.

The Tracy finite-element model was used because it offered the most practical combination of features required to meet the project objectives. The finite-element method was desirable because it added flexibility in grid design and allowed a more accurate simulation of the boundary conditions associated with the stream-aquifer interface and the bedrock-bounded limits of the relatively narrow alluvial aquifer. When compared to other methods, the finite-element formulation appeared to provide greater detail with less truncation error for the smallest expenditure of computer storage space and computational time. The Tracy model was selected over other finite-element models because it accounts for transient conditions of streamflow with unprecedented detail for large-scale stream-aquifer simulation, and it provides a complete itemization of the stream-aquifer water budget. 

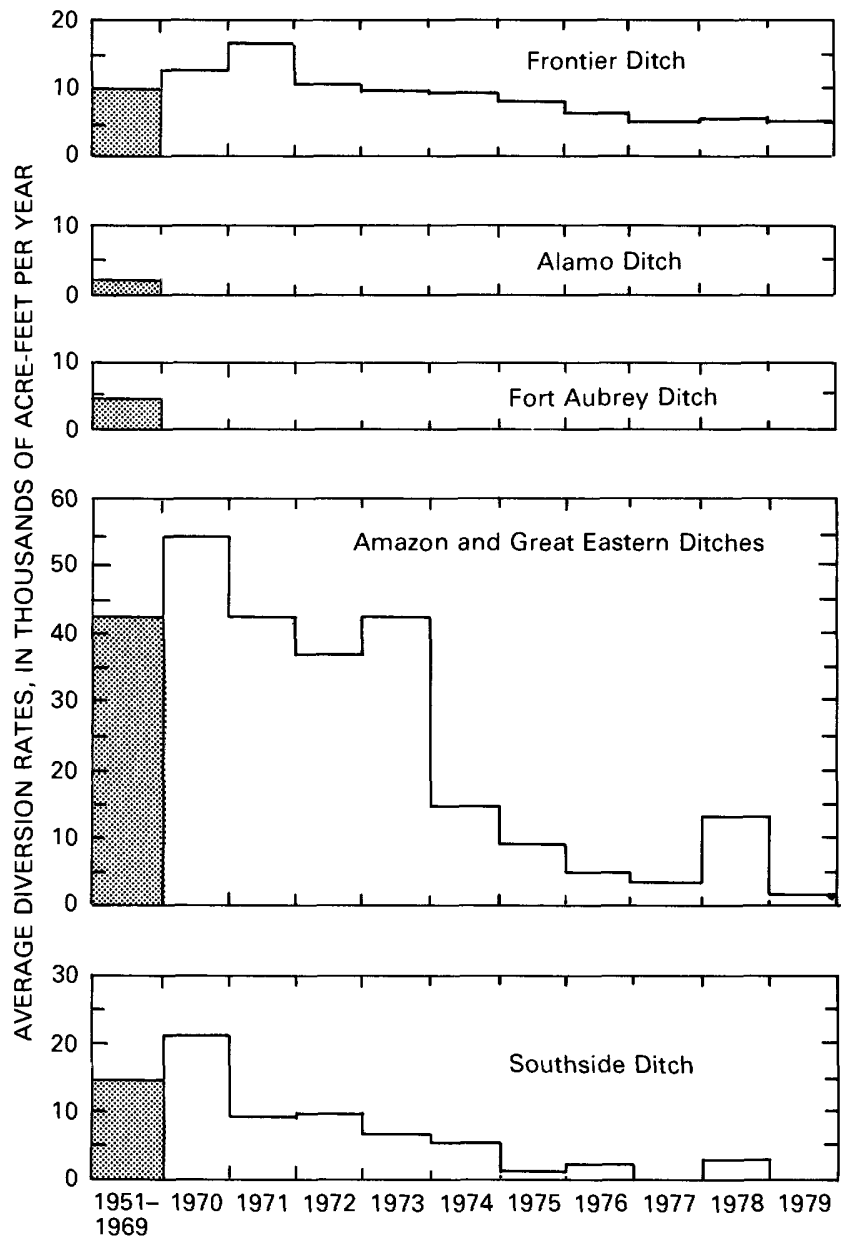

Figure 18. Average annual diversion rates by irrigation ditches, 1951-69 and 1970-79.

\section{Flow Equation}

The general equation of two-dimensional groundwater flow (Bredehoeft and Pinder, 1970), referred to as the flow equation hereafter, under water-table conditions is:

$$
\frac{\delta}{\delta x}\left(K b \frac{\delta h}{\delta x}\right)+\frac{\delta}{\delta y}\left(K b \frac{\delta h}{\delta y}\right)=S_{y} \frac{\delta h}{\delta t}+Q
$$

where

$x, y=$ space coordinates, in feet;

$K=$ aquifer hydraulic conductivity, in feet per day;

$b=$ saturated thickness, in feet;

$h=$ hydraulic head, or water level, in feet;

$S y=$ specific yield, dimensionless;

$t=$ time, in days, and

$Q=$ unit rate of vertical flux, in feet per day.
The vertical flow term, $Q$, in equation 2 includes the vertical components of the modeled flow system. The components of vertical flux are: (1) Pumpage, (2) streamaquifer leakage, (3) deep percolation, and (4) groundwater evapotranspiration. These items are discussed individually under the "Vertical Flux" section of this report.

The digital-computer model cannot solve equation 2 directly. The model instead uses a finite-element numerical technique to approximate the equation in an iterative, piecemeal fashion for one finite part of the hydrologic system at a time. Numerical analysis transforms the dimensions of space and time into parts small enough that the errors associated with linear representations of nonlinear conditions do not violate the desired criterion for goodness of fit, or closure.

A simple, physical analogy to the finite-element numerical technique is that of fitting a curve (such as a hydrograph) with a series of straight lines. Any single line can be extended only so far in this process before the line diverges from the curve. The only choice to prevent unsatisfactory divergence is to shorten the line and use another link to pursue the curvature.

This analogy can be extended into two dimensions if we attempt to fit a warped surface (a water table, for example) with a flexible network of three-sided planes. The idea is to approximate continuous, two-dimensional curved space with a systematic assemblage of small, flat triangles. The triangles need to be small enough to conform, yet large enough to be practical. As the degree of warp (two-dimensional curvature) in the real surface increases, the triangles need to both decrease in size and increase in number to maintain a given accuracy of approximation. So, the required size and number of triangles depends on the complexity of the simulation and on the demands for accuracy; therein lies a basic principle of finite-element approximation.

The triangular planes in the finite-element flow model are defined by the position of their corners, called nodes. The resulting triangles are called elements. The nodes are positioned to provide the required representation of the stream-aquifer system. Nodes and elements are numbered systematically so that hydrologic definition can be addressed to specific parts of the system.

\section{Finite-Element Grid and Time Steps}

The numerical solution of the flow equation is controlled by the finite-element grid, shown in figure 20 . The grid was structured by positioning the nodes so that the resulting elements span, as completely as practical, the limits of the modeled stream-aquifer system. 


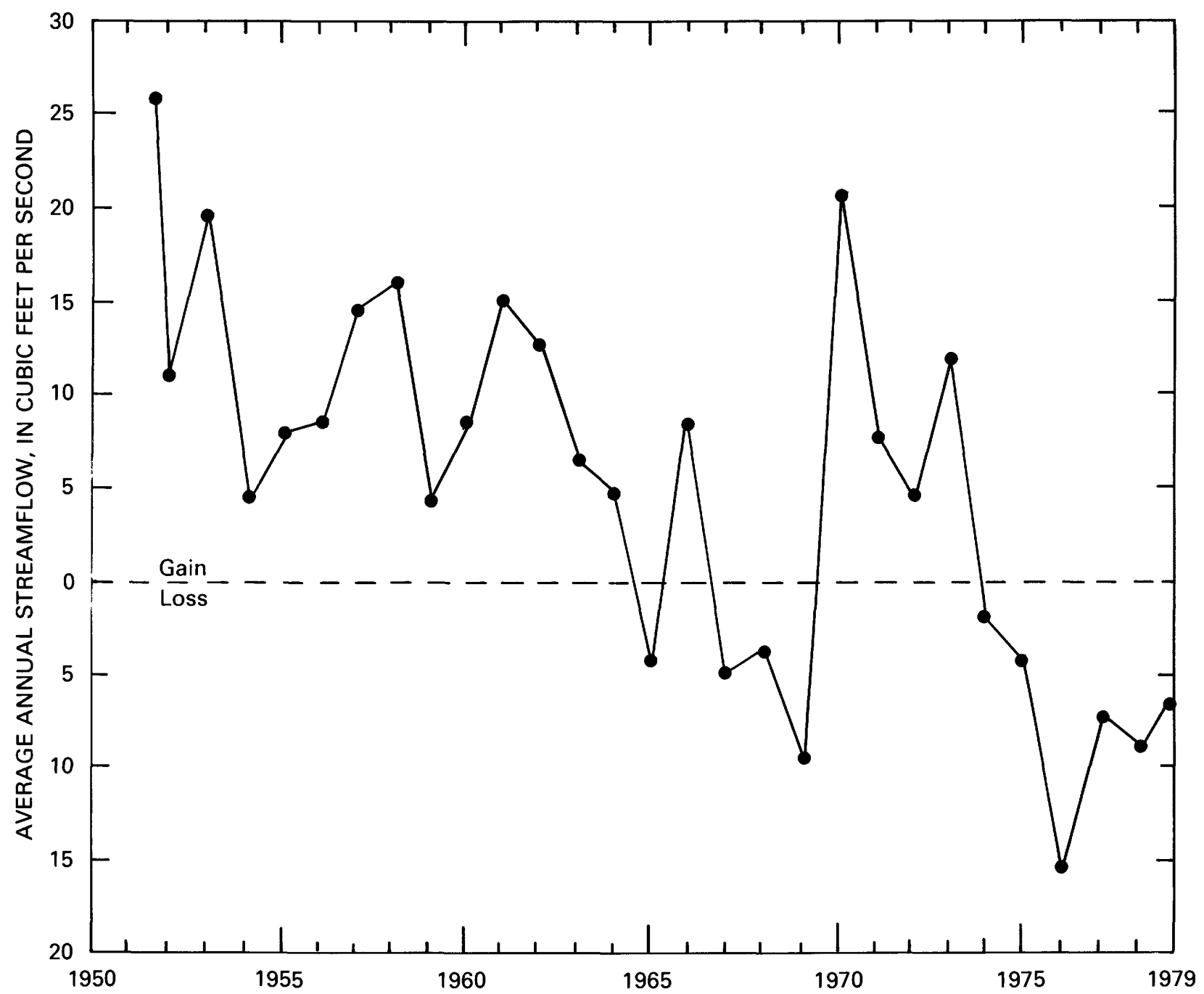

Figure 19. Average annual streamflow gain and loss of Arkansas River between Coolidge and Syracuse, 195179 .

The grid provides a two-dimensional system of nodes numbering 9 (north-to-south) by 39 (east-to-west) for a total of 351. This arrangement provides 608 triangular elements. Eighty-seven special purpose riverbed nodes are used to orient the simulation of stream-aquifer interconnection and to route streamflow.

Just as the space dimension needs to be fragmented to permit numerical approximation of the flow equation, simulation of transient conditions requires that time be broken into a series of finite intervals, called time steps. To minimize truncation error and to provide sufficient detail of simulated conditions, a progression of 5-day time steps was used for all transient analyses.

\section{Calibration Strategy}

Development of the computer model as a predictive tool is based on the premise that, if historic hydrologic phenomena can be satisfactorily approximated by the model, then so should future conditions. For this presumption to hold, the historic cause-and-effect relationship between stresses in the real flow system and the system's response to those stresses needs to be simulated accurately. It is further required that this cause-and-effect relationship does not change significantly in the real system during the period for which responses are predicted. The model of the Arkansas River valley was developed over 
a 1-year period, during which time the pertinent geohydrologic characteristics of the real flow system were incorporated as data input to a FORTRAN computer program. Most of the developmental time was spent calibrating the data input to reproduce the cause-and-effect relationships among historic conditions of precipitation, irrigation, streamflow, pumpage, consumptive use, and water levels. During calibration, input data, such as hydraulic conductivity, leakance, specific yield, and soil-moisture-holding capacity, were adjusted within the limits of sound hydrologic judgment and principles until the model could provide a satisfactory approximation of the measured response.

The model was calibrated for both steady-state and transient conditions. The steady-state model was formulated first and served as a basis for the transient-model design. The transient model is an extention of the steadystate model wherein subsequent nonsteady stresses are superimposed and the dimension of time and the effects of changes in ground-water storage are considered. Although each model includes much of the same program logic and input data, each represents a different set of conditions, thus requiring adjustments of different data in each to achieve calibration. Because the success of transient simulation proved to be so dependent on the rates of vertical flux (which were adjusted during experimentation with the steady- state model), calibration became basically a process of alternating steady-state simulations with transient simulations and attempting to make corrections between each simulation that were mutually agreeable to both models.

To insure that the transient model would simulate future conditions in the real system, it was necessary that it first simulate, with reasonable accuracy, as much hydrologic history as practical. Thus, it was important to carefully choose a calibration period, or the time span for which the model was calibrated to approximate observed hydrologic conditions. Choice of a calibration period was dictated by: (1) The availability of calibration data and (2) the actual hydrologic relationships among precipitation, streamflow, and water levels.

About 1970 , the stream-aquifer system in the study area began to have year-to-year reductions in streamflow and water-level declines that continued into the 1980's. It was considered particularly desirable that this period of unprecedented development and response be used for the transient calibration period. The transient model, however, requires a set of conditions from which to start, called initial conditions.

The steady-state modeling effort was the first of two steps required to provide initial conditions for transient simulation of hydrologic activity during the 1970's.
For the purposes of establishing initial conditions for the 1970-79 transient simulation, it was assumed that an average of historic conditions between 1951-69 provides a reasonably good representation of a steady-state situation that most likely existed prior to about 1970 .

By definition, steady-state is a situation of equilibrium. Solution of the steady-state flow equation requires that recharge equal discharge and that stress and flux do not change with time; as a result, there is no hydraulichead change nor change of water in storage. The steadystate condition is a relatively simple situation that, in the strictest sense, never exists in a large-scale stream-aquifer system. Although possible to define mathematically, it is an improbable condition owing to the complexity of real systems. The conditions can be approximated, however, by averaging observations of historic water levels and time-dependent sources of recharge and discharge.

If the hydrologic system of interest undergoes change of a uniform and cyclic nature, such as shown by water-level fluctuation in response to seasonal changes in precipitation and streamflow, then the average of these conditions over time can satisfy the requirements for steady state. The key requirement is that, during the period used for averaging, all significant departures from the norm are canceled by departures of similar magnitude and duration in the opposite direction. In general, the results of averaging become more representative of the steadystate situation as the period of averaging increases.

Inspection of the historic precipitation, streamflow, and water-level data for the area (fig. 14) indicates that hydrologic activity between 1951-69 was dominated by cyclic response to cyclic stress and relatively moderate fluctuations in recharge and discharge. It follows conceptually that, during the 19 years prior to 1970 , about as much water entered the stream-aquifer system as discharged from it and, when averaged over the period, the observed conditions approximate an equilibrium situation. In such a time-condensed representation, hydrologic conditions are constant in time.

To obtain the input for the steady-state simulation, therefore, the time-dependent stresses (table 1) were first averaged to obtain mean monthly rates applicable to the 1951-69 era. These mean monthly rates were summed for January through December then divided by 12 to provide instantaneous rates of steady-state stress, which are time-independent and consistent with the mathematical concept of steady-state.

The model's solution to the steady-state problem (as defined by the time-averaged input) is not expected to represent exactly the conditions for January 1, 1970, the beginning date of the 1970-79 transient simulation. 
Table 1. Outline of data input to model of Arkansas River valley

FIXED-IN-TIME

Time, space, and hydraulic conditions for simulation

Location of boundary nodes

Specific yield

Hydraulic conductivity

Land-surface altitudes

Finite-element grid

Stream data

Location of riverbed nodes

Riverbed lengths and widths

Riverbed leakance

Stage-discharge relationships

State line - Syracuse

Syracuse - Kendall

Kendall - Amazon

Amazon - Hartland Crossing

TIME DEPENDENT

Boundary conditions

Daily rates of State line streamflow

Monthly rates of precipitation

Monthly rates of evapotranspiration

Soil and actual evapotranspiration characteristics

Number of wells and surface-water applications.

Percentage of ground and surface water applied

Pumpage and irrigation distribution

Seasonal variation

Location and rate

At best, the steady-state model represents the average, or typical, hydraulic state of the system between 1951-69. To provide average January 1 conditions for the 1951-69 era, the mean monthly data was cycled in a transient simulation for 6 years to reach a new equilibrium under timedependent conditions. For this model simulation, which generated the initial water levels for the 1970-79 transient model, it was assumed that the specific-yield distribution was the same as used for subsequent 1970-79 simulations.

For brevity, the calibrated steady-state model will be called the "steady-state" model. The transient simulations using the mean monthly input for 1951-69 will be called the "pre-1970 transient" model, and the calibrated transient simulations for 1970-79 will be called the "1970-79 transient" model. Results of the steady-state, the pre-1970, and the 1970-79 simulations are provided in the section on "Simulated Hydrologic Response."

\section{Simulated Hydrologic Properties}

In hydrologic modeling terminology, the flow of water through a unit cross-sectional area within a unit time is called hydraulic flux. Although flux may occur in any direction, it is usually most expedient when designing a ground water-surface water flow model to consider flux as occurring in only the vertical and horizontal directions. Any errors resulting from this generalization are not significant for most flow systems because the total amount of water involved is preserved. In both the model and in actuality, when a difference occurs between the total flux into the system (recharge) and the total flux from the system (discharge), a change of water in storage results. Water levels rise or decline, accordingly. Any phenomenon in the hydrologic system that causes flux is called a hydraulic stress.

Response of a stream-aquifer system to stress, such as pumpage or incoming streamflow, depends on: (1) The proximity and nature of the hydraulic and geologic boundaries, (2) the hydraülic characteristics of the aquifer and streambed, and (3) the distribution of recharge to, and discharge from, the system. These properties were incorporated into the computer model of the Arkansas River valley to provide a simulated account of water levels and streamflow in response to simulated stresses.

The underlying philosophy in calibrating the model was to use simple, area- or time-constant distributions of input data until the data were proven incorrect or insufficiently detailed during calibration. During calibration of the model, most time and effort was spent refining the accuracy of data input that simulation results were most dependent upon and sensitive to changes within. The stream-aquifer system is too complex to be modeled exactly; owing to limitations in the availability and accuracy of data, some generalizations and assumptions are inherent in the model input. This section of the report describes the necessary interpretations of the data and points out the generalizations involved in the translation of onsite observations to the model.

\section{Boundary Conditions}

Boundary conditions are specified to terminate lateral ground-water flow at the northern and southern boundaries of the modeled system and to maintain proper water levels at the western and eastern edges. In order for the model to solve the ground-water flow equation, either the hydraulic head or the flux at each boundary node needs to be specified; the model cannot solve for these as it does for the interior nodes. The conventions used to provide the required boundary information for these nodes are the no-flow and specified hydraulic-head boundaries (fig. 20). 


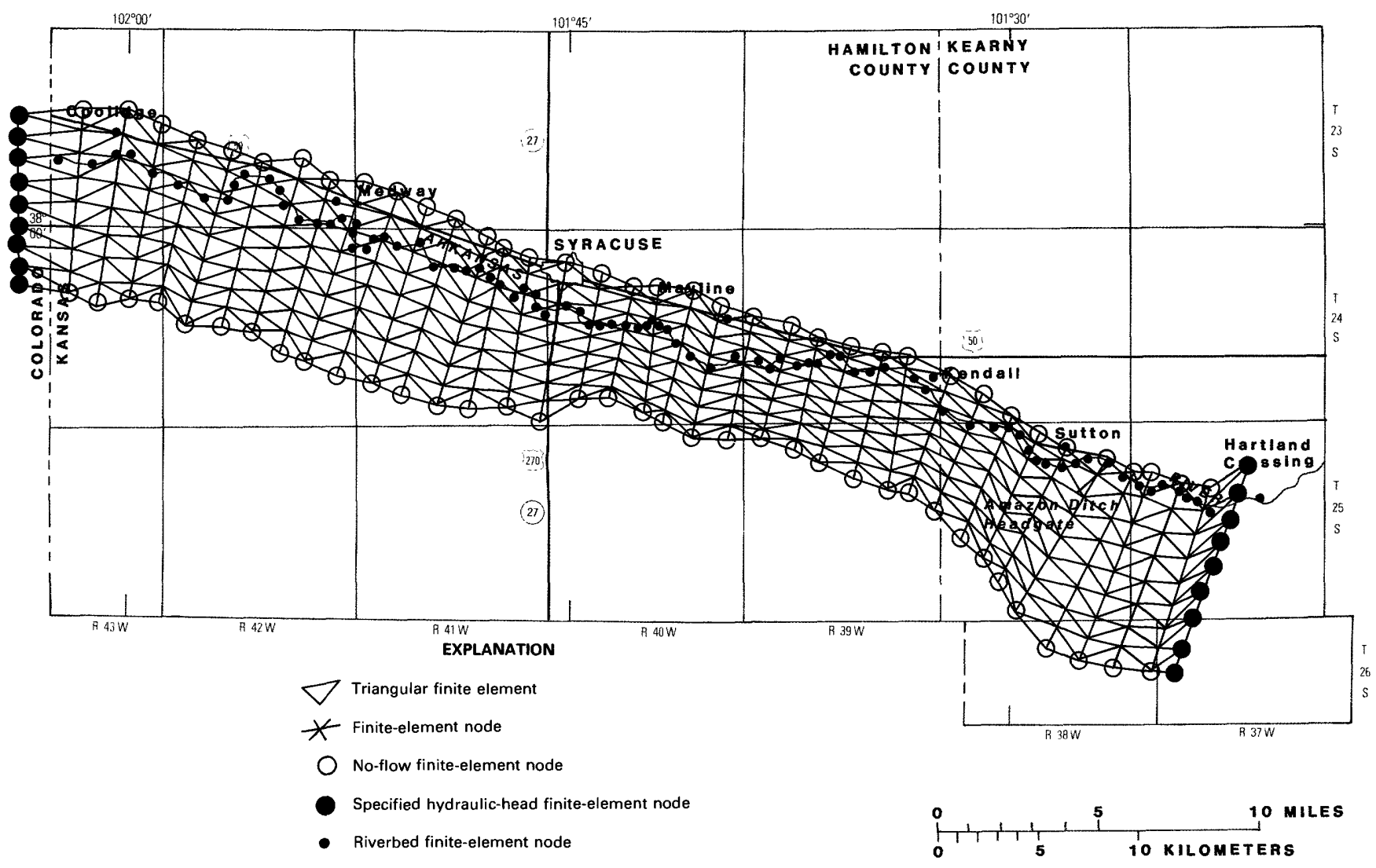

Figure 20. Elements and finite-element, no-flow, specified-head, and riverbed nodes within the finite-element grid.

The no-flow boundary is used to depict the effects resulting from the alluvial aquifer system's thinning to termination on the north and south against the relatively impervious bedrock. The effect of having no lateral flow across these boundaries is accomplished in the model by assigning zero hydraulic conductivities to the finite-element nodes where this condition exists. There are 74 noflow nodes in the Arkansas River valley model.

Specified hydraulic-head boundaries are used to maintain water levels at those nodes representing areas of lateral inflow (near the Colorado-Kansas State line) and lateral outflow (near Hartland Crossing). Specified hydraulic-heads at these locations allow the model to simulate the change in inflow and outflow that occur due to changes in water levels across the area.

Model water levels at the 18 specified hydraulichead nodes (fig. 20) were updated at the beginning of each time step during calibration simulations with the 1970-79 twansient model. These boundary water levels were updated at a uniform rate and are based on the observed decline of water levels between 1970-79 in wells near the upstream (25-37W-15ABA) and downstream (25-37W-15DDD) boundaries. The rate of decline thus simulated between $1970-79$ is 4.3 feet for all specified hydraulic-head nodes along the western boundary and 3.9 feet for those along the eastern boundary. This rate of decline at these boundaries, equaling $0.4 \mathrm{ft} / \mathrm{yr}$, was continued during all projection simulations from January 1980 to December 1982 (see section entitled "Hypothetical Situations").

\section{Streamflow}

In addition to the finite-element aquifer nodes, the model uses 87 riverbed nodes to control the simulation of stream-aquifer interaction and to orient the routing of river discharge from the Colorado-Kansas State line to the downstream limits of the modeled area (fig. 20). The geometric configuration of the stream channel is translated to the model according to the position of the riverbed nodes. The riverbed nodes are positioned such that the general path of the channel is approximated by straight lines that link adjacent riverbed nodes. 
Streambed altitude, lengths, and widths are specified for each riverbed node as part of the model input. The length and width data represent nodal-reach dimensions as shown schematically in figure 21 . Streambed altitudes were interpolated from 1:24,000 scale ( 1 inch $=2,000$ feet) U.S. Geological Survey topographic maps with 5-foot topographic-contour intervals. These streambed altitudes were related to altitudes of streamgage datum at Coolidge, Syracuse, Kendall, and downstream from the Amazon Ditch headgate. Streambed lengths (applicable over the nodal reach, as shown in figure 21) were planimetered from 1:10,000 scale (1 inch $=833$ feet); areal photography was taken in July 1978 . The planimetered values are rounded to the nearest 50 feet in the model input.

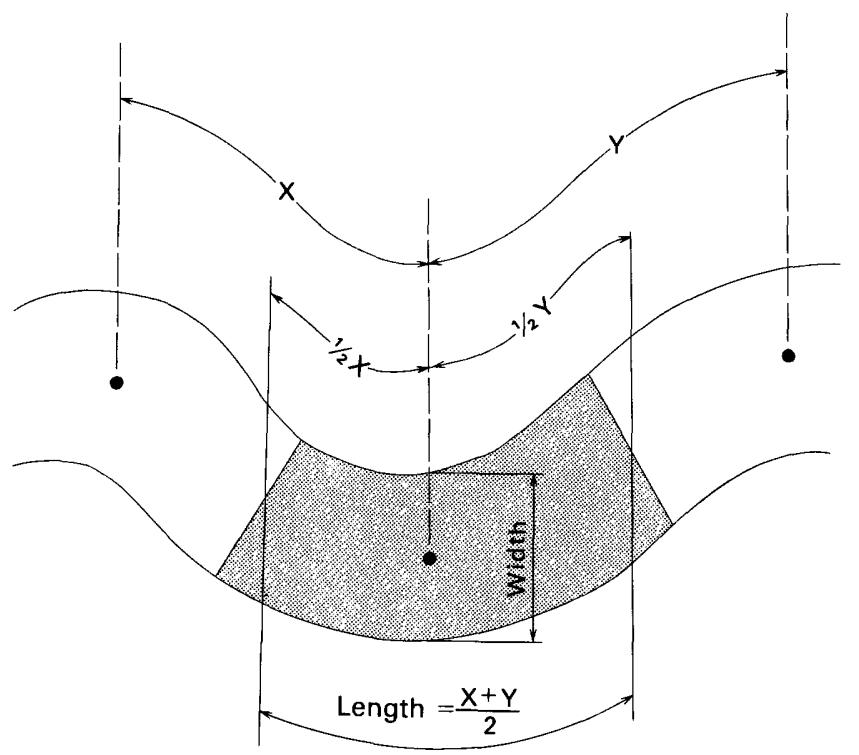

EXPLANATION

Riverbed reach $\bullet$ Riverbed node

Figure 21. Method of determining riverbed-reach dimensions for model input.

Although wetted-width dimensions along the river can vary from year to year, from day to day, or even from one hour to the next depending on discharge, it was not practical to translate this variability to the model. Hydraulic effects of the relatively limited variability in width were assumed to be insignificant in comparison to the effects owing to the associated changes in stream stage (which area accounted for during simulation).

For this reason, a value of 20 feet was used everywhere as the effective year-around width. Recent (1975-
80) onsite observations show this to be the most appropriate single value to represent the relatively steep-banked reaches between the State line and Hartland Crossing. Although prior to about 1975 , the effective riverbed widths were probably greater than 20 feet, the effect of the differences in width between then and now (1980) does not seem to have affected significantly the calibration of the model.

The model simulates rates of streamflow for all riverbed nodes in an iterative, upstream-to-downstream fashion. Starting with input streamflow at the uppermost stream node and working downstream, the flow is calculated for each reach on the basis of incoming flow (from the upstream reach) and the gain from, or loss to, the aquifer throughout the length of the reach. As detailed in the section on "Stream-Aquifer Leakage," the gains and losses are calculated as a function of streambed area and leakance and the gradient between the stream and aquifer.

Gaged daily flow at Coolidge is used for initial streamflow conditions at the uppermost stream node, near the Colorado-Kansas State line. The model averages the input streamflow (in cubic feet per second) throughout the length of the 5-day model time step to make the streamflow simulation compatible with simulated aquifer activity. The output streamflow rates are, therefore, applicable to the 5-day time steps. During transient calibration runs, the output streamflow rates for Syracuse, Kendall, and downstream from the Amazon Ditch headgate were averaged further to obtain mean monthly discharge for comparison to gaged streamflow.

\section{Hydraulic Conductivity}

Hydraulic conductivity, a measure of the aquifer's ability to transmit water, is used by the model in combination with hydraulic head-dependent saturated thickness to compute the required transmissivity distribution during simulation. Although transmissivity changes during simulation by virtue of simulated water-level change, the hydraulic conductivity is constant in time.

An area-constant hydraulic conductivity of $800 \mathrm{ft} / \mathrm{d}$ is used in the calibrated model for the Arkansas River alluvium. Although variability in hydraulic conductivity does exist in the alluvium, owing to insufficient data to support the effort and because model results are relatively insensitive to local variations in hydraulic conductivity, no attempt was made to define the variability.

The single exception to uniform hydraulic-conductivity input is that for five nodes near the eastern edge of the model grid that coincide with a narrow ridge of outcropping sandstone just south of the Arkansas River (fig. 7). Because sandstone aquifers in the area have hydraulic conductivities that generally are 1,000 times less than that for the alluvium (Lobmeyer and Sauer, 1974), a value of $0.8 \mathrm{ft} / \mathrm{d}$ was assigned to the sandstone area. 
Additionally, an initial saturated thickness of 20 feet was assumed for the sandstone area. The combination of the extremely small hydraulic conductivity and the limited saturated thickness allows the model to simulate the effects of the relatively impermeable bedrock on the stream and alluvial aquifer, while maintaining the required non-zero continuity in the transmissivity distribution of the model.

The calibrated value of $800 \mathrm{ft} / \mathrm{d}$ is relatively large for alluvial aquifers; however, the value is substantiated by previous investigations and by analysis during the study. Reported hydraulic-conductivity values range from $508 \mathrm{ft} / \mathrm{d}$ in Kearny County (Gutentag, Lobmeyer, and McGovern, 1972) to $1,200 \mathrm{ft} / \mathrm{d}$ in Hamilton County (Lobmeyer and Sauer, 1974) for the Arkansas River valley. Based upon a flood-wave response procedure outlined by Grubb and Zehner (1973), measurements of aquifer response to stage fluctuations in the river at Syracuse between June 20, and September 20,1978, were used to estimate diffusivity (ratio of transmissivity to storage coefficient) for that area of the alluvium. Assuming an average storage coefficient of 0.17 and accounting for the local saturated thickness of about 65 feet, estimates of hydraulic conductivity from flood-wave response analyses range from about 500 to $800 \mathrm{ft} / \mathrm{d}$. Estimates of transmissivity made from specific-capacity (well yield divided by drawdown) data, as suggested by Theis (1963), yield values of hydraulic conductivity that average about $400 \mathrm{ft} / \mathrm{d}$.

Although different magnitudes and distributions of hydraulic conductivity were used during early stages of calibration, a parameter-estimation technique (Cooley, 1977) was used ultimately to establish the single value of $800 \mathrm{ft} / \mathrm{d}$. A parameter-estimation version of the Tracy finite-element model (J. V. Tracy, U.S. Geological Survey, written commun., 1980) used a statistical procedure to calculate values of hydraulic conductivity that, when used for simulation, minimized the sum of the squared deviations between measured and simulated steady-state water levels. Additionally, the parameter-estimation model provided information with which to judge the sensitivity of simulated results to changes in the model input. Because the hydraulic-conductivity value of $800 \mathrm{ft} / \mathrm{d}$ (provided by the paramerter-estimation method with a percent standard error 0.59 ) provided the best overall reproduction of measured streamflow and water levels in the steadystate and the 1970-79 transient simulations, it was assumed for subsequent model analyses.

\section{Specific Yield}

The magnitude of water-level change that occurs in a water-table aquifer in response to recharge or discharge of ground water depends on the specific yield. The water-level rise or decline per unit volume of water introduced to or removed from the aquifer is inversely proportional to the specific yield. Specific yield is related to the degree of sorting and porosity of the sand and gravel aquifer; the greater the porosity or the better the sorting, the greater the specific yield. Typical values of specific yield for alluvial aquifers range from about 0.1 to 0.25 .

The Arkansas River model uses a simple distribution of specific yield that ranges in value from 0.14 to 0.20 . During early stages of model development, it became apparent that the model provided better reproductions of historic conditions when using greater values of specific yield near the western margins of the model area and lesser values near the eastern end. Moore and Wood (1967) and Taylor and Luckey (1974) reported a specificyield value of 0.20 for the river valley alluvium in Colorado, and Gutentag, Lobmeyer, and McGovern (1972) reported a value of 0.14 for the Arkansas River alluvium in Kearny County. Because the model's calibration needs are supported by results of past investigations, the model distribution was derived by mathematically grading a value of 0.20 for the westernmost edge of modeled grid to 0.14 for the easternmost edge (fig. 22). Although somewhat aribitrary, this distribution helped the model simulate seasonal drawdowns that resembled those recently measured in the model area.

\section{Vertical Flux}

The most important fluxes in the stream-aquifer system of the Arkansas River valley are those entering and leaving in the vertical direction. The amount of water entering the aquifer vertically (via deep percolation and stream leakage) is presently (1975-79) about 65,000 acre$\mathrm{ft} / \mathrm{yr}$, nearly 7 times that entering laterally. This section of the report describes the system's vertical fluxes-those that directly affect the amount of water in storage and, therefore, the water levels in the alluvial aquifer.

\section{Pumpage}

The largest vertical discharge from the aquifer is pumpage. Annual pumpage has increased from about 18,000 acre-ft during 1970 to nearly 65,000 acre- $\mathrm{ft}$ during 1979 (fig. 23). During this time, the number of irrigation and public-supply wells increased from 89 to 160 . The areal distribution of the 1979 pumpage is shown in figure 24.

Knowing the time and areal distibution of historic pumpage was required for successful calibration of the computer model. Any errors in the model pumpage data necessitate compensating errors in other model input to achieve an apparent approximation of historical conditions. For this reason, a substantial effort was made during the study to insure that the model pumpage data were as complete and accurate as practical.

The pumpage history of the modeled area was reconstructed for the pre-1970 and the 1970-79 calibration periods by making an inventory of public-supply and irrigation wells in the area and by computing monthly rates of pumpage for those wells from energy-consumption and (in a few instances) water-right and billing records. Area- 


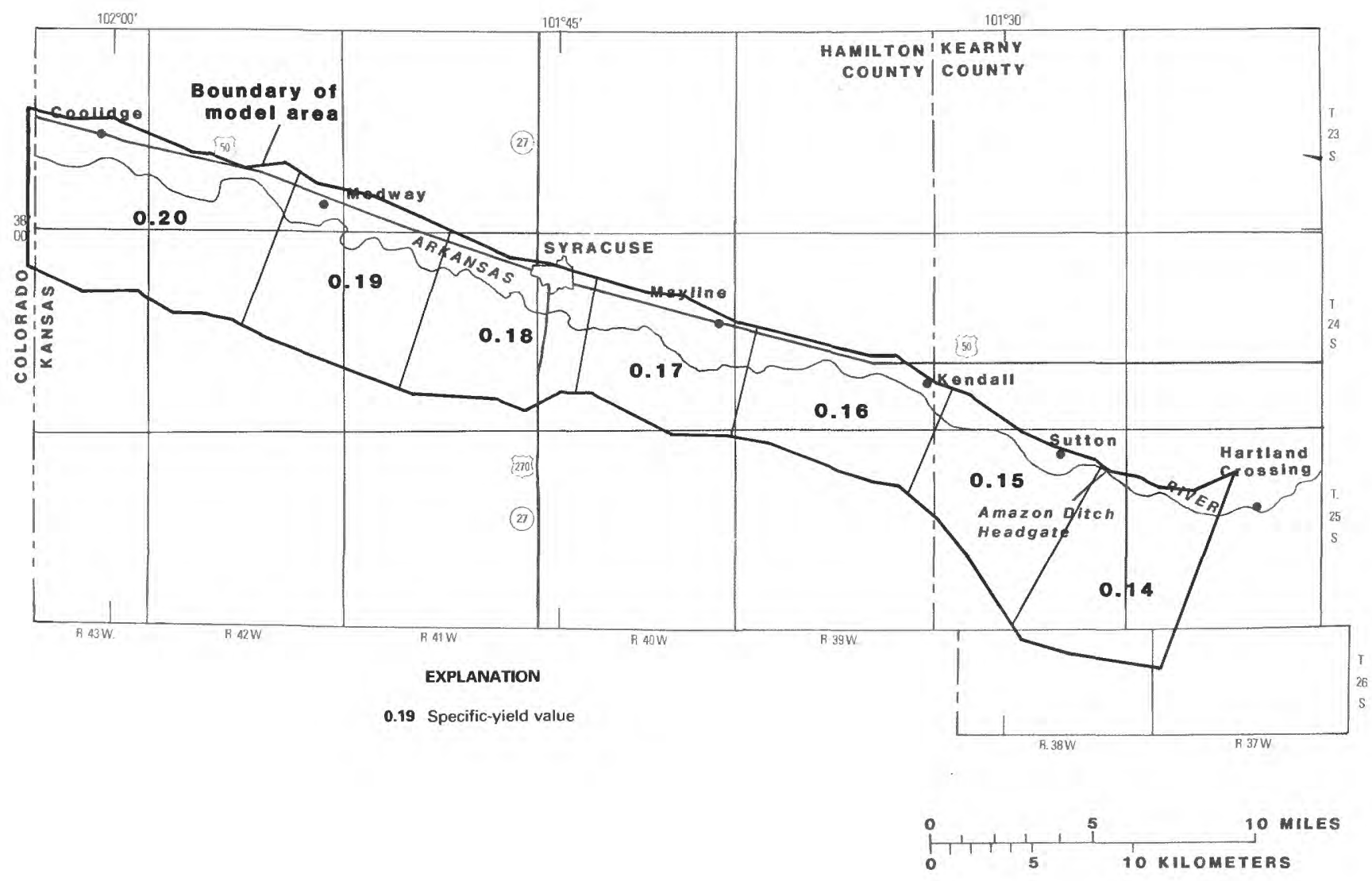

Figure 22. Distribution of calibrated specific yield within model area.

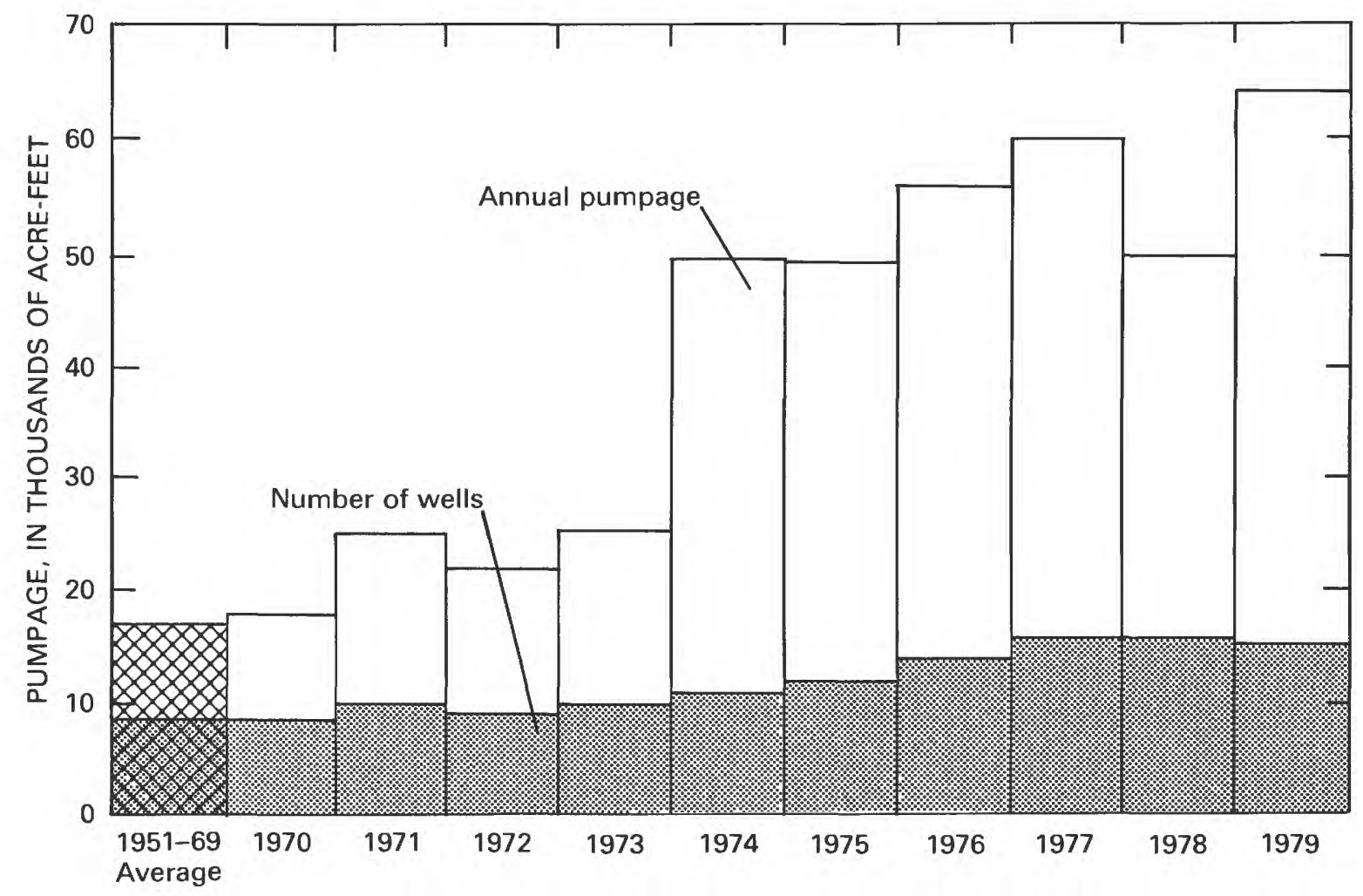

Figure 23. Annual pumpage and number of wells for 1951-69 and 1970-79. 


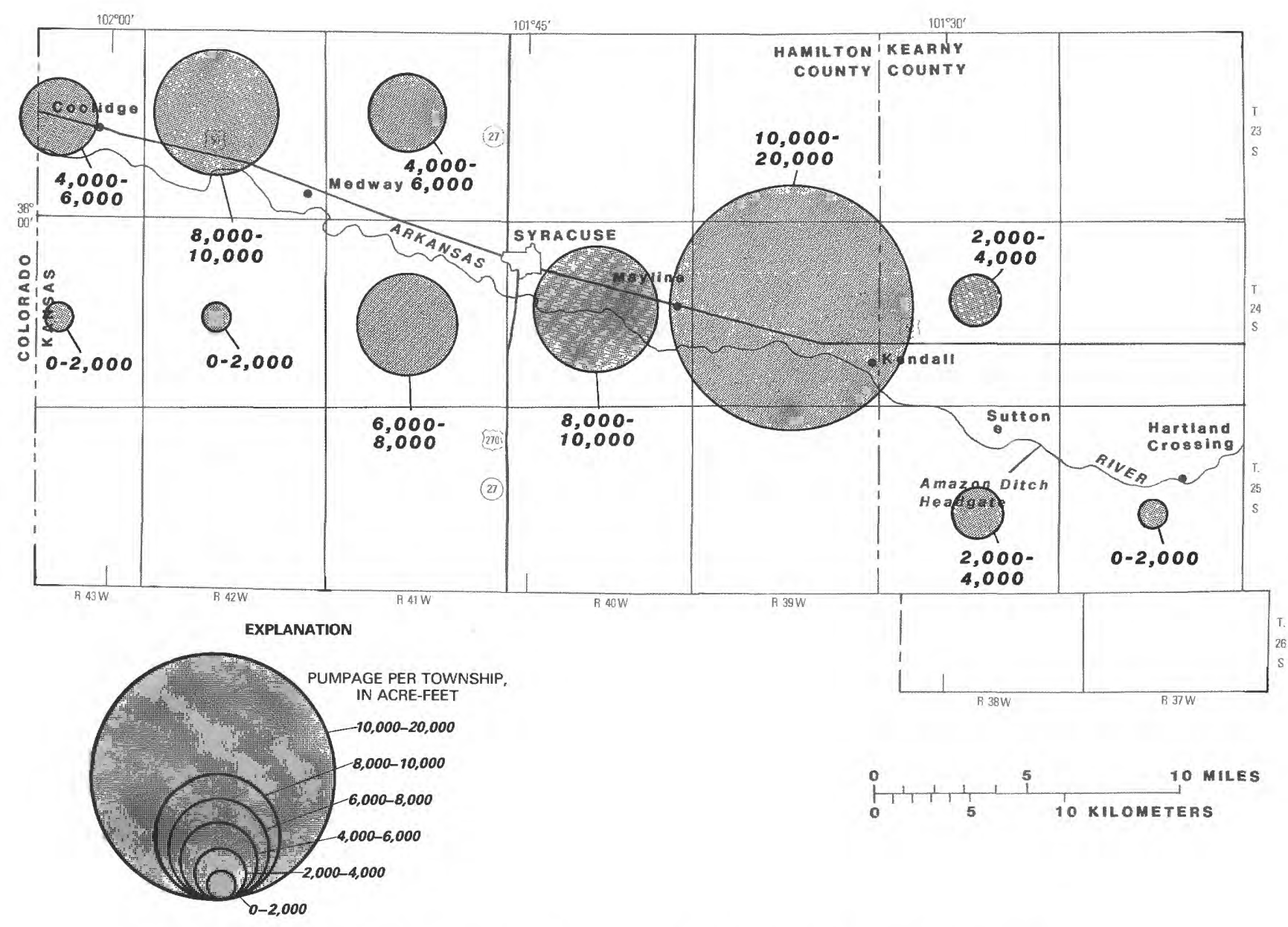

Figure 24. Areal distribution of pumpage from Arkansas River alluvium, 1979.

wide averages were determined from monthly rates of pumpage, where available, and applied to annual totals for other wells to provide the monthly patterns of pumpage throughout the area.

The inventory was made during 1977-78 and updated during July 1979. The wells were inventoried for: (1) owner's name, (2) date of installation, (3) average line pressure, (4) motor horsepower, (5) location, and (6) other pertinent data. Locations of the wells are shown on plate 1. Although a considerable effort was made to inventory all active pumping sites, a few could have been overlooked because apparently abandoned wells are sometimes reactivated. Cross checking the inventory against waterright and utility-company records substantiate, however, that the inventory is at least 95 -percent complete.

Of the 160 alluvial-aquifer wells inventoried for 1979, the pumps on 136 (or 85 percent) operate from electricity. The remaining 24 use other sources of energy, including natural gas, diesel, and liquified-petroleum gas. Except for three public- supply wells operated by the City of Syracuse, all wells are used for irrigation.
Monthly rates of metered public-supply pumpage were obtained from the city clerk in Syracuse. Quarterly pumpage rates were computed from records of natural-gas consumption for nine irrigation installations in the study area. Annual pumpage rates for the remaining 15 users of nonelectric energy were estimated from water-right data maintained by the Division of Water Resources, Kansas State Board of Agriculture. Monthly pumpage rates were computed for all the electric-driven pumps from records of kilowatt-hour consumption.

The use of energy-consumption records to estimate pumpage distributions has been used successfully in various areas of the United States and is described in numerous reports including those by Olgilbee and Mitten (1970), Sandberg (1966), and McClelland (1963). This method was chosen to compile pumpage data for the Arkansas River valley study because other choices were either impractical or could not provide sufficient detail. It was not feasible, for example, to purchase and install totalizing flow meters to obtain data for 1 or 2 years during the study, when the calibration requirements for the model 
dictated a need for 10 years of data. Similarly, water-right information generally is applicable to annual rates of water use and does not reflect necessarily actual pumpage patterns.

The basis of computing pumpage from energy use is shown by

Pumpage $=$ Energy use

Total hydraulic head x Energy-discharge factor

Energy use for more than 90 percent of the inventoried wells was obtained from utility companies serving the area. Total hydraulic head was computed from observations and computations of pumping lift and measurements of line pressure. The appropriate energy-discharge factors were obtained for the electric installations from a sampling of 14 percent of those sites.

The energy-discharge factor is a variable related inversely to the overall, or "wire-to-water", efficiency of the pumping installation. Because efficiency usually increases with motor horsepower, energy-discharge factors generally decrease in value for the larger installations with greater motor horsepower. For electric installations, the units of the energy- discharge factor are kilowatt-hours per acre-foot of pumpage per foot of hydraulic head.

The sampling activity to obtain representative energy- discharge factors for the study area included: (1) The gaging of instantaneous rates of pump discharge and energy consumption, (2) the measuring of associated pumping lift and line pressure, and (3) the collection of appropriate watt-hour meter constants from the utility company. Results of the sampling an subsequent analysis provide energy-discharge factors for electric installations of 2.20 $(\mathrm{kWh} / \mathrm{acre}-\mathrm{ft}) / \mathrm{ft}$ for pumps with a motor horsepower of 30 or less and $1.98(\mathrm{kWh} / \mathrm{acre}-\mathrm{ft}) / \mathrm{ft}$ for those with over 30 motor horsepower. An appropriate energy-discharge factor for natural-gas installations was calculated to be $20.30\left(\mathrm{ft}^{3} / \mathrm{acre}-\mathrm{ft}\right) / \mathrm{ft}$, assuming the Nebraska Performance Standards for deep-well turbine pumping plants (Schleusener and Sulek, 1959).

Total hydraulic head is equal to the sum of linepressure hydraulic head and pumping lift. Although observations of line pressure were made at all sites, it was impractical to measure pumping lifts at other than a few sites due to the concern of property owners over the possibility of damage to their pumps. Pumping lifts were, therefore, estimated with the Theis (1935) nonsteady-state equation in combination with the Jacob (1944) correction for unconfined aquifer conditions. Transmissivities were computed (for use in the Theis analysis) assuming an effective "well-bore hydraulic conductivity" of $400 \mathrm{ft} / \mathrm{d}$ and a saturated thickness applicable to the location of each well. All wells were pumped for 30 days at a discharge equal to their certified water right, if available. If unavailable, the discharge was estimated from the relationship with motor horsepower shown in figure 25 . This relationship was developed from data for the nearly 100 sites where the motor horsepower-to- discharge ratios are known from inventory and water-right certification. Although many generalizations are inherent in the procedure used to obtain total hydraulic-head data, the shortcomings are considered minimal in comparison to those associated with the (discarded) alternative of not considering the effect of total hydraulic head on pumpage in the area.

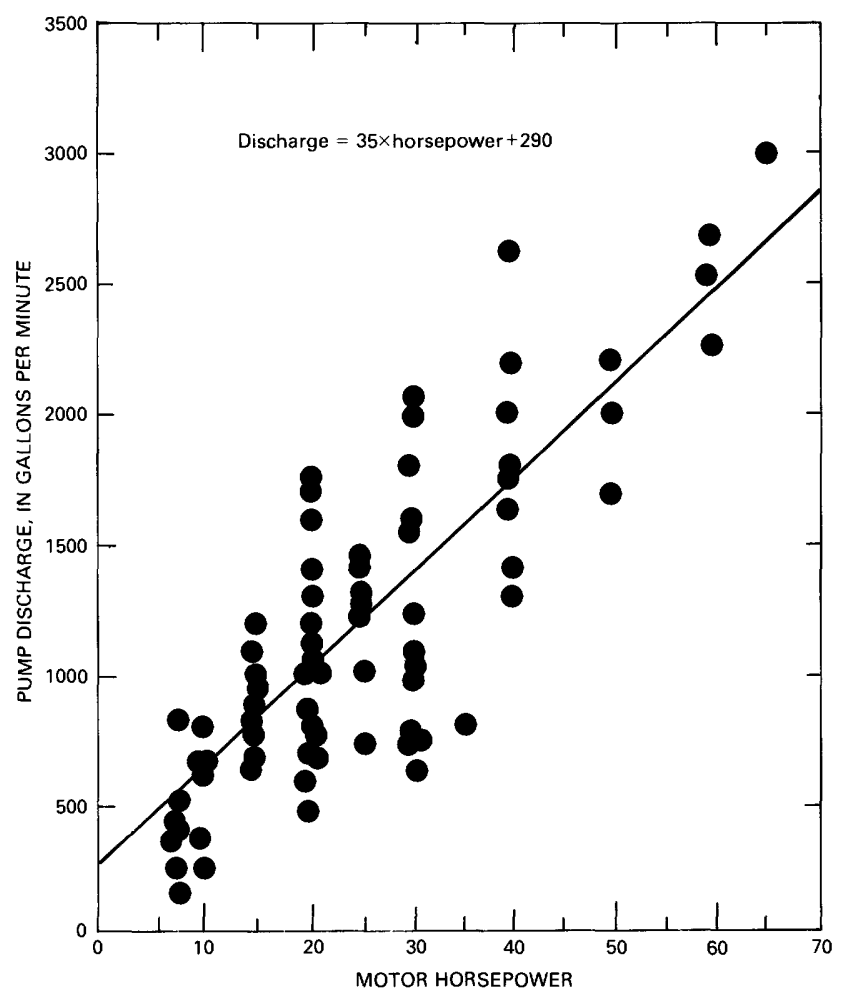

Figure 25. Relationship between electric-motor horsepower and pump discharge.

For compatibility with other time-dependent input, the model requires monthly pumpage data. Monthly rates of pumpage are available for only the electric-driven pumps in the study area. Therefore, the ratios of monthly to annual totals for the electric-driven pumps were used to distribute the pumpage on a monthly basis throughout the modeled area. The average of these monthly distributions for $1970-79$ is shown in figure 26 for both irrigation and public-supply wells.

A check on the validity of the energy-conversion method of obtaining pumpage input for the model is provided by comparing metered pumpage by the three publicsupply wells at Syracuse to that computer from kilowatthour consumption at the same wells. The resulting discrepancies for 1975-78 (when both metered and consumption records are available) are: $-38,-59,+43$, and -49 acre-ft. These discrepancies are, on the average, within 


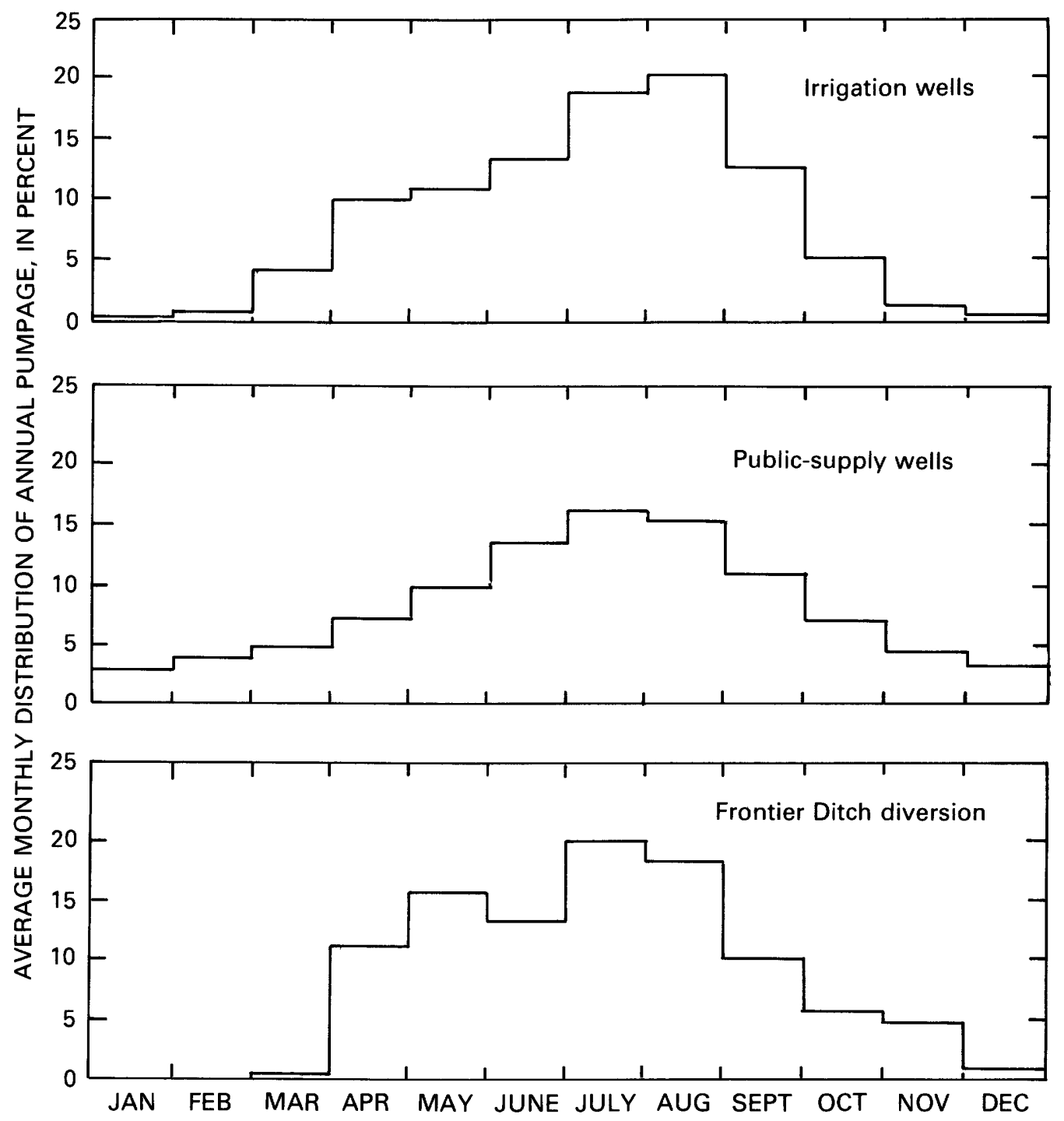

Figure 26. Average monthly distribution of total annual pumpage by irrigation and publicsupply wells and of surface-water diversion through Frontier Ditch, 1970-79.

8 percent of the metered amounts. Discrepancies of this magnitude indicate that the method of energy use-to-pumpage conversion provides adequate pumpage data with which to calibrate the model.

\section{Stream-Aquifer Leakage}

The exchange of water between the Arkansas River and the alluvium occurs through the streambed and is simulated in the model according to:

$$
Q=\frac{k^{\prime}}{b^{\prime}}\left(h_{s}-h_{a}\right) A
$$

where

$Q=$ rate of leakage, in cubic feet per second;

$\frac{k^{\prime}}{b^{\prime}}=$ Streambed leakance, or ratio of hydraulic conductivity of streambed, in feet per day, to thickness of streambed, in feet;

$h_{s}=$ altitude of stream stage, in feet;

$h_{a}=$ altitude of water table, in feet; and

$A=$ wetted area of streambed reach, in square feet.

A leakance value of $1.34 \mathrm{~d}^{-1}$ is used for all riverbed nodes in the model. This value was derived largely by trial-and-error simulation with the attempt to simulate his- 
torical rates of mean monthly streamflow at Syracuse, Kendall, and downstream from the Amazon Ditch headgate. The value agrees favorably with streambed hydraulic-conductivity values published for the Arkansas River valley in Colorado and with values calculated from results of recent seepage tests in the area during the study.

Moore and Jenkins (1966, p. 695-696) determined infiltration rates of 1.87 and $2.27 \mathrm{ft} / \mathrm{d}$ for stream reaches near La Junta, Colo., and concluded that "...clay and silt 'sealants' appear to limit the maximum infiltration rate to about $20\left(\mathrm{gal} / \mathrm{ft}^{2}\right) / \mathrm{d}[2.67 \mathrm{ft} / \mathrm{d}]$.', Gain-loss tests were made in the study area during April 1978 and April 1980 on five reaches of the Arkansas River. These tests yielded measurements of streambed hydraulic conductivity that range from 0.78 to $1.64 \mathrm{ft} / \mathrm{d}$ and average $1.21 \mathrm{ft} / \mathrm{d}$. The model's value of $1.34 \mathrm{~d}^{-1}$ for leakance appears reasonable in comparison to the measured data, assuming that the effective streambed thickness $\left(b^{\prime}\right)$ is 1 foot, or slightly less.

The hydraulic gradient between the stream and aquifer is determined by the difference between the altitude of stream stage $\left(h_{s}\right)$ and altitude of the water table $\left(h_{a}\right)$. Values of $h_{a}$ are simulated as part of the finite-element solution to the ground-water flow equation. The appropriate $h_{s}$ is computed during simulation from: (1) The simulated upstream discharge, (2) the streambed altitude, and (3) the stage-discharge relationships, from streamflowgaging-station rating curves. Altitudes of stream stage computed for reaches between the State line and Syracuse are based on rating curves for the Arkansas River near Coolidge. Likewise, rating curves for the river at Syracuse, at Kendall, and downstream from the Amazon Ditch headgate are used, respectively, for the simulation of stage altitudes from Syracuse to Kendall, from Kendall to the Amazon Ditch headgate, and from the headgate to Hartland Crossing.

The area of wetted streambed, $A$, is computed from the input value of streambed width and length, as discussed earlier in the section on "Streamflow."

\section{Deep Percolation}

Vertical recharge to the ground-water system occurs as water infiltrates from the land surface through the soil zone to the aquifer. The sources of water that may infiltrate from the land surface are precipitation and irrigation water (from both well pumpage and surface-water diversion). Collectively, these sources are called incident water.

Incident water on the land can either: (1) run off the surface as direct runoff, (2) infiltrate as deep percolation, or (3) be consumed by plants as actual evapotranspi- ration. The Tracy model uses an algorithm developed by the U.S. Department of Agriculture (1967) to divide incident water between two of the three possibilities, deep percolation and actual evapotranspiration; direct runoff is not accounted for separately and, in effect, may increase the deep-percolation component of incident water. Direct runoff is not simulated because of the impracticality of having to define the physical and climatic conditions that control the separation in the field. The generalized approach is not considered to have affected significantly the calibration of the Arkansas River valley model, nor is it considered a liability when projecting the long-term effects of water distribution.

The relative amounts of incident water that are simulated as eventually going to either deep percolation or actual evapotranspiration depend on the rate of incident water, the rate of consumptive-use demand, and the moisture-holding capacity of the soil zone. Given a constant rate of incident water, the greater the rate of consumptiveuse demand or the larger the moisture-holding capacity, the greater the rate of actual evapotranspiration and the smaller the rate of deep percolation.

The simulation of incident water by the model is based on the sum of pumpage (fig. 23), surface-water diversion via the Frontier, Alamo, and Fort Aubrey Ditches (fig. 18), and precipitation (fig. 14). The simulated precipitation is distributed equally to all elements of the finite-element grid. Irrigation water originating as well pumpage is directed to specific elements, based on the proximity of the irrigated acreage. Diverted surface water is applied likewise to areas of gravity irrigation within the appropriate ditch systems (fig. 9). The elements receiving either pumpage or diverted surface water, or both, during simulation are shown in figure 27 .

The model uses a single, composite consumptiveuse demand for all model nodes for any given month of simulation. The different consumptive-use demands resulting from the five major crop and land-use categories (see "Land Use" section) are incorporated in that composite value; the composite is an area-weighted average of the individual consumptive-use demands. Rates of consumptive-use demand simulated in the pre-1970 and the 197079 transient models are shown in figure 28 . The moistureholding capacity of the soil zone was determined from trial-and-error simulation to be 9 inches. Conceptually, the 9 inches relates to the capacity of an 8-foot soil section to hold moisture that eventually is consumed as actual evapotranspiration. An 8-foot soil section is assumed to be the limiting depth of moisture extraction from the unsaturated zone by most crops, native ground cover, and the shallower-rooted riparian vegetation in the area. The 


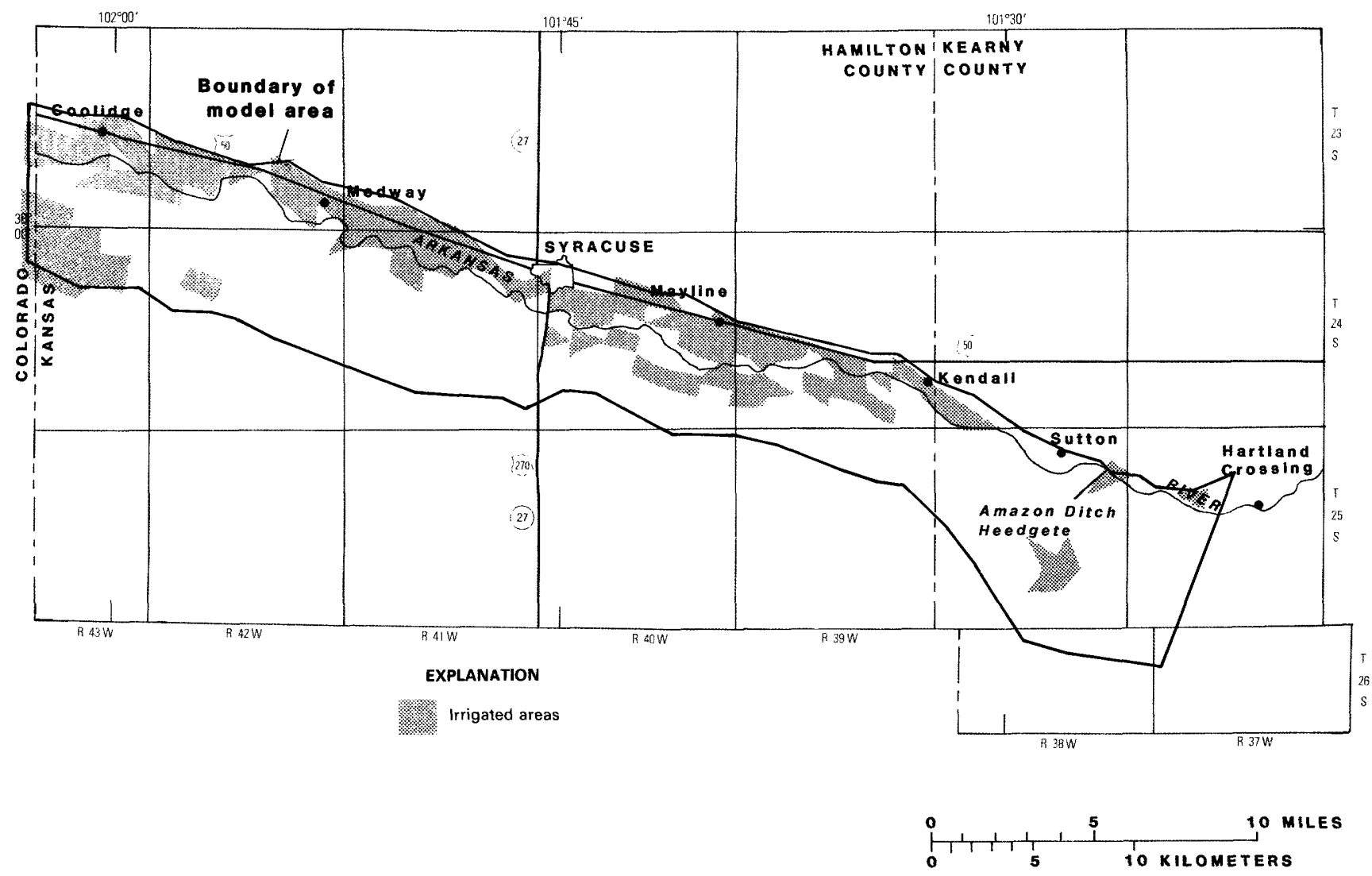

Figure 27. Areas of simulated irrigation applications within model area.

moisture-holding capacity of 9 inches per 8 feet converts to 0.09 inch of moisture per 1 inch of soil column, which complies with the average value of "available water capacity" given for the clay loam and sandy loam "...soils in the valleys of the Arkansas River..." by the U.S. Department of Agriculture (1963, p. 38-41). Simulated rates of deep percolation and actual evapotranspiration that result from the steady-state, the pre-1970 transient, and the 1970-79 transient runs are provided in the section on "Simulated Hydrologic Response."

\section{Ground-Water Evapotranspiration}

Significant discharge can occur from the Arkansas River alluvial aquifer as ground-water evapotranspiration when the water table is above the root zone or within reach of roots through capillary attraction. In conjunction with the attempt during simulation to satisfy consumptiveuse demands, water is extracted directly from the aquifer if the demands are not first met by water available at the surface through precipitation and irrigation. The resulting ground-water evapotranspiration reduces or cancels the evapotranspiration deficit (remaining consumptive-use demand) and is simulated according to the relationship shown in figure 29 .

Ground-water evapotranspiration can completely satisfy the evapotranspiration deficit if the water table is at or above land surface. That part of the deficit that can be met when the water table is below land surface declines 


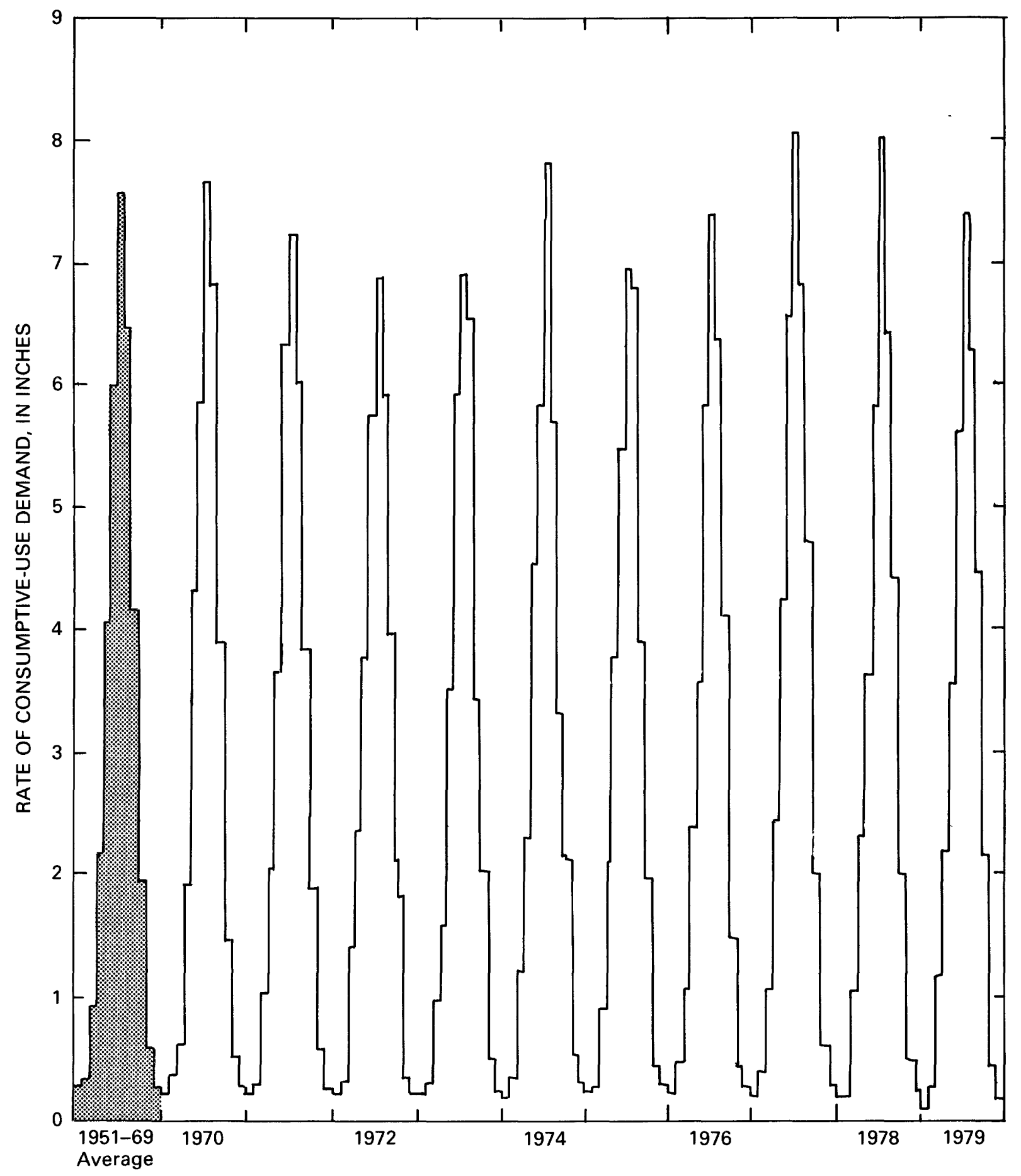

Figure 28. Simulated rates of consumptive-use demand for 1951-69 and 1970-79. 
about 8 percent per each additional foot below land surface, reaching 0 at depths of 12 feet and greater. This relationship was established largely on the basis of trialand-error simulation and the presumed water-extraction capability of the deeper rooted plants, such as alfalfa and phreatophyte growth along the river bottomland.

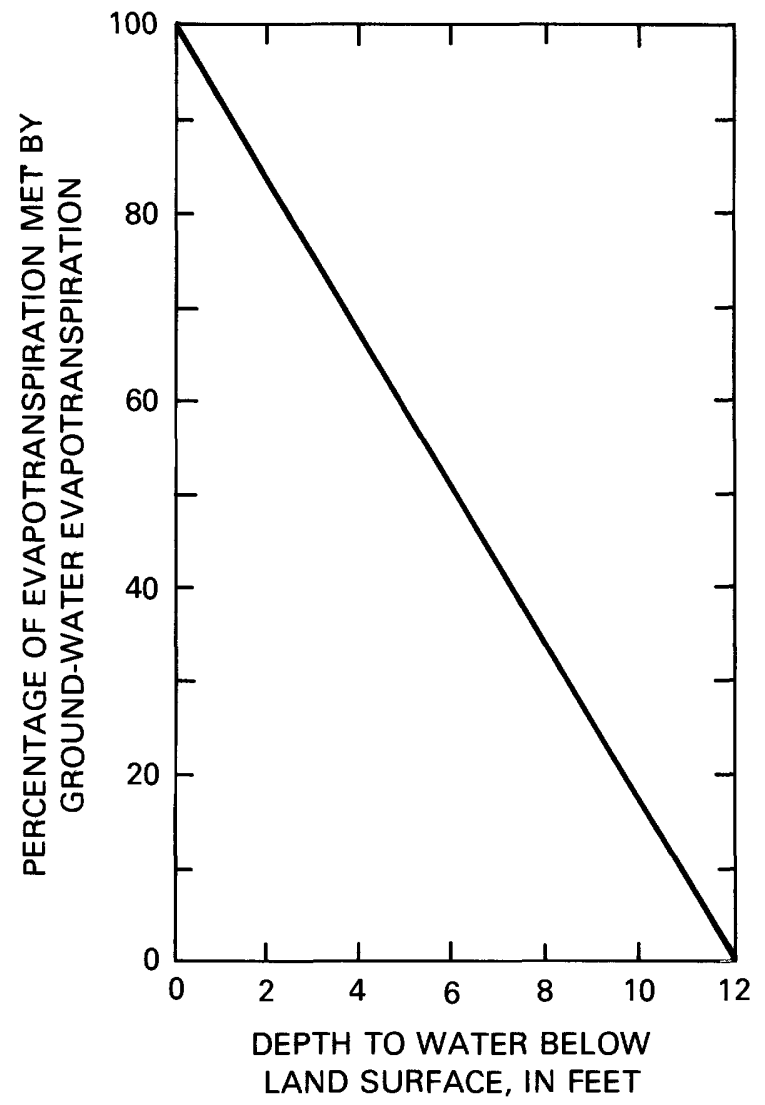

Figure 29. Relationship between depth to water table and ground-water evapotranspiration.

\section{Simulated Hydrologic Response}

\section{Historic Situations}

Before the model could be considered suitable for projecting stream-aquifer response to hypothetical hydrologic conditions, it was necessary that it demonstrate a reasonable ability to simulate observed historic responses to historic conditions. The model's reliability was monitored during the calibration effort by comparing simulated water levels and water-budget items to those supported by actual measurement or deduced from hydrologic observation and interpretation. This section of the report provides comparisons of simulated and measured water levels and streamflow and a water-budget tabulation for 195169, 1970-74, and 1975-79.

\section{Steady State}

The steady-state model is a numerical representation of the stream-aquifer system prior to 1970 , or before the unprecedented stress and response to that stress during 1970-79. For the purposes of calibration, it was assumed that an average of historic hydrologic conditions observed between 1951-69 represents a steady-state situation. Owing to the scarcity of data with which to define the steady-state conceptualization, there is not a unique solution to the steady-state analysis; different combinations of vertical flux, hydraulic conductivity, and streambed leakance will provide a seemingly adequate simulation of the presumed steady-state situation. Validity of the steadystate model was not assumed, therefore, until reasonably appropriate transient simulations followed, using the generated steady-state water levels as initial conditions.

The areal distribution of assumed steady-state water levels and those simulated with the steady-state model are shown in figure 30. Assumed steady-state, water-level contours were drawn from pre-1970 measurements.

The only historic streamflow data amenable to comparison with those simulated for the steady-state period are the recorded discharges of the Arkansas River at Syracuse. The average streamflow gaged at Syracuse between $1951-69$ is $232.5 \mathrm{ft}^{3} / \mathrm{s}$. The calibrated steady-state model simulates a value of $227.7 \mathrm{ft}^{3} / \mathrm{s}$, which is $4.8 \mathrm{ft}^{3} / \mathrm{s}$ (or 2 percent) less than the historic value. Correction for diversion (via the Fort Aubrey and Alamo Ditches) and for return (Frontier and Fort Aubrey Ditches) nets a +6.4 $\mathrm{ft}^{3} / \mathrm{s}$, reducing the deviation to $1.6 \mathrm{ft}^{3} / \mathrm{s}$ (or less than 1 percent) of the averaged gaged flow during 1951-69.

The deviations between the assumed steady-state water levels and streamflow and those simulated with the steady-state model are, theoretically, a measure of the error of the model. Because the deviations are insignificant, however, in consideration of the generalized nature of the steady-state conceptualization, any further attempt to improve the model on the basis of these deviations was deemed impractical and unjustified.

\section{Transient}

Transient simulation for calibration purposes was done in two steps. First, output water levels from the steady-state simulation were used as initial conditions in the pre-1970 transient model (see "Calibration Strategy") to generate from 1951-69 mean monthly input initial water levels applicable to January 1970. Second, these January 1970 water levels were used as initial conditions for the 1970-79 transient simulation.

Because the pre-1970 model cycles through monthly data applicable to average conditions during the 1951-69 era, its output should correspond to the assumed average conditions of streamflow and water levels. Although water-level data for this period are extremely lim- 


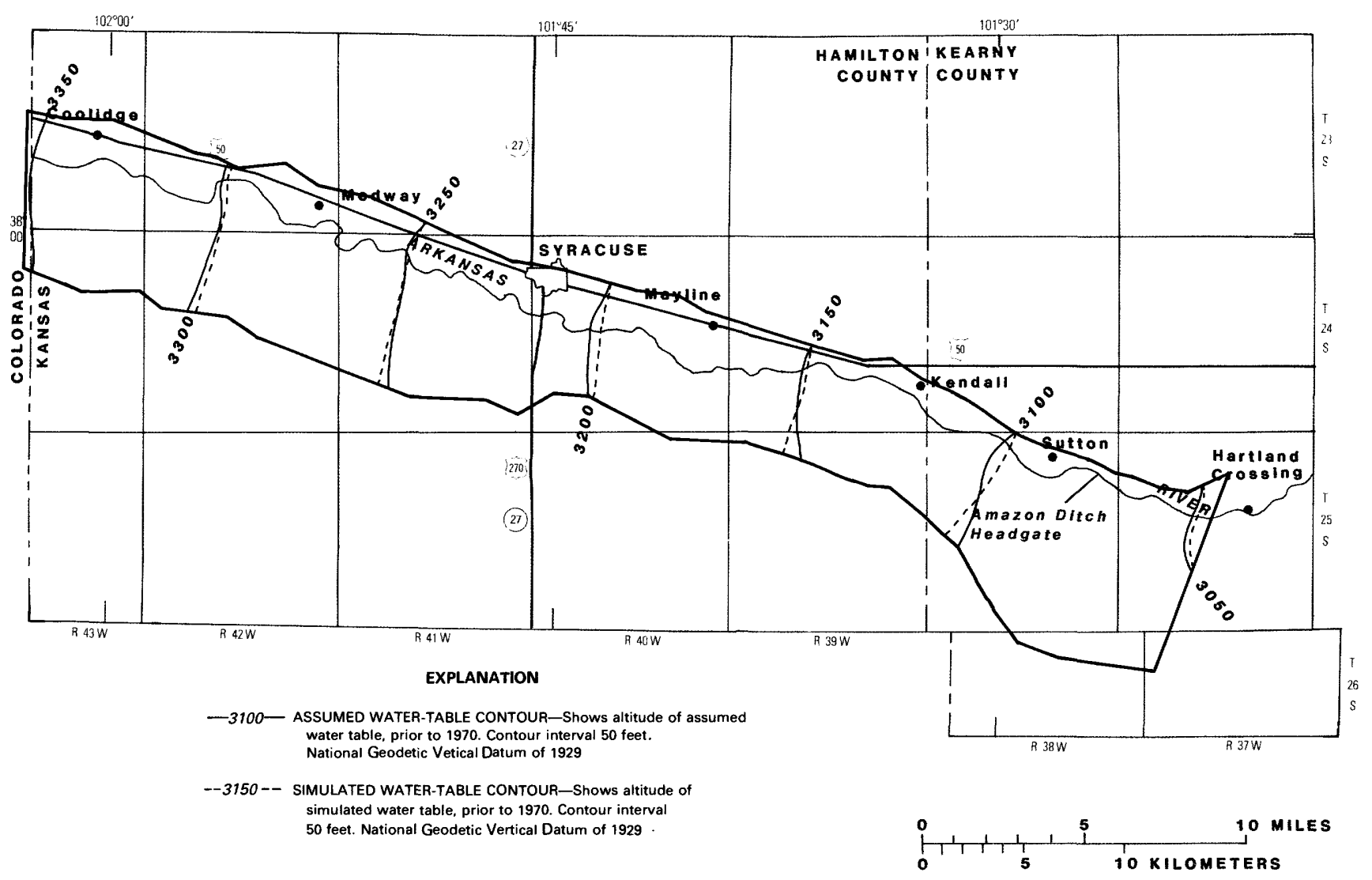

Figure 30. Assumed and simulated steady-state water-level contours within model area, prior to 1970.

ited, the Arkansas River was gaged at Syracuse during 1951-69, thus allowing a comparison of gaged and simulated mean monthly streamflow (fig. 31). The simulated data in figure 31 are adjusted in accord with the net diversion (via the Fort Aubrey and Alamo Ditches) and return (Frontier and Fort Aubrey Ditches) between Coolidge and Syracuse.

Because the model does not simulate directly the effect of diversion from and return to the Arkansas River, the simulated streamflow can be adjusted where appropriate for significant additions or losses that are external to the simulation of stream-aquifer flux. As evident in figure 31 , however, the significance of ditch diversion and return is relatively minor in comparison to the flow in the river.

For the 1970-79 and future simulations, the following conditions exist: (1) The Fort Aubrey and Alamo Ditches no longer operate, and (2) return and tributary inflow are extremely variable and difficult to calculate or anticipate on a consistent basis. For these reasons and because the effects are generally insignificant, it is assumed that no adjustments are necessary for simulated streamflow between the State line and headgate of Ama- zon Ditch (fig. 9). To provide an appropriate basis for streamflow comparison for reaches downstream from the Amazon Ditch headgate, however, the rates of diversion through the Amazon Ditch are added to the gaged Arkansas River flow (downstream from the headgate) for comparisons of simulated and measured streamflow in this report. This correction to make gaged and simulated streamflow compatible is required only for reaches downstream from the Amazon Ditch headgate and only for periods of diversion through Amazon Ditch.

A comparison of simulated and measured water levels during 1970-79 is shown in figure 32. A comparison of simulated and historic streamflow hydrographs during 1970-79 is shown in figure 33. Contours of water levels simulated for December 31, 1979, were compared to altitudes of water levels measured during January 1980 , as shown in figure 34 .

The measured water levels in figure 32 are the same as those shown in figure 15 and are from wells indexed in figure 2. The simulated water levels are for the finiteelement nodes nearest the respective wells. The graph's 


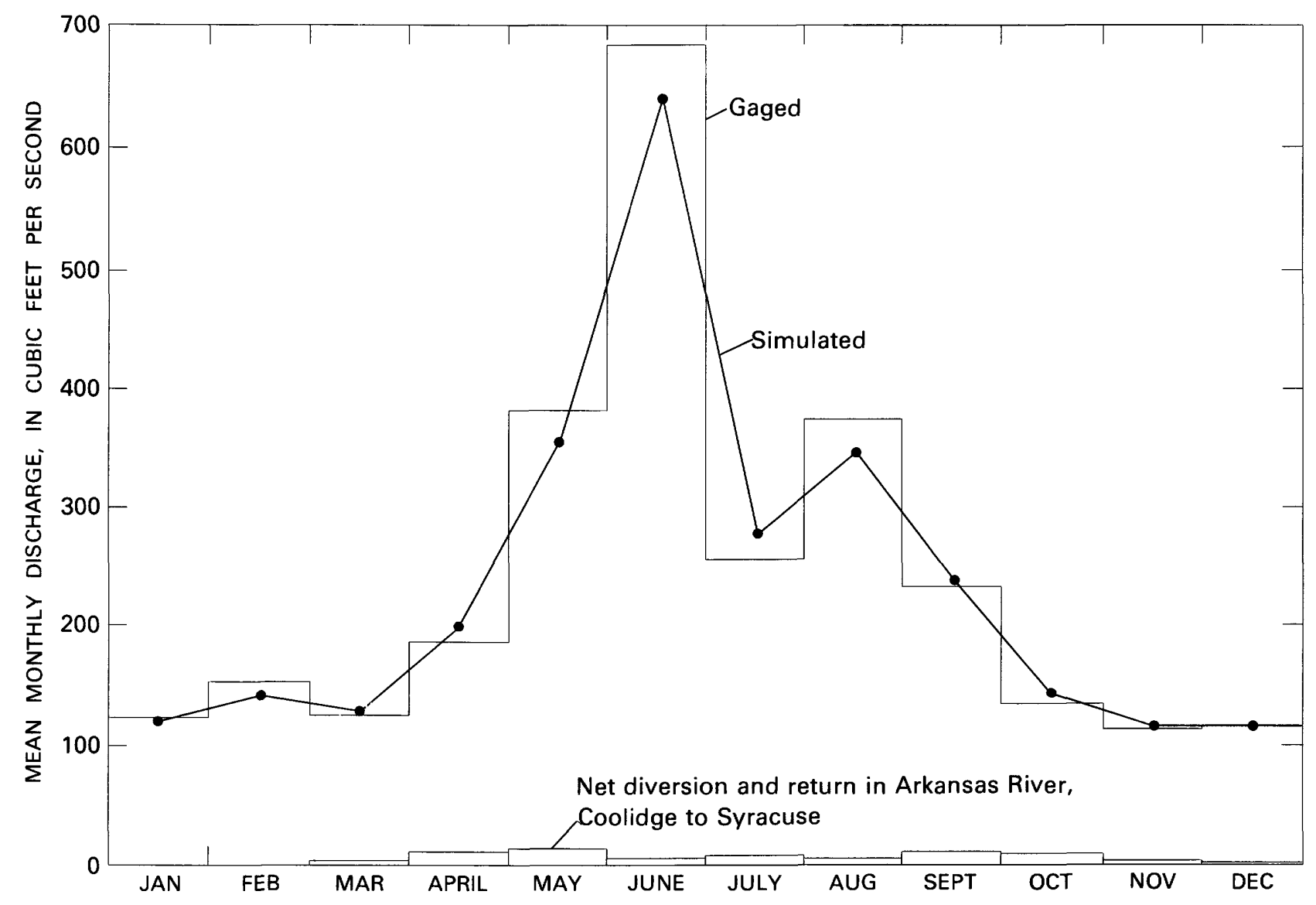

Figure 31. Gaged and simulated mean monthly discharge of Arkansas River at Syracuse, 1951-69.

reference value is the output water levels from the pre1970 transient simulation. The location of five finite-element nodes that are used to provide simulated water levels for subsequent illustrations are shown in figure 35. The nodes are labeled according to their sequential finite-element grid positions (fig. 20).

Some of the disparity between simulated amd measured water levels (fig. 32) results because the simulated water levels are not computed exactly for the location of the wells from which the historical levels were measured. The seasonal differences are most likely due to the use of area-wide averages in the model to control monthly rates of well pumping (discussed in section on "Pumpage").

The most prominent differences in the streamflow comparisons (fig. 33) result during periods of high flow. In almost all instances of high flow, the model simulates streamflow rates that are less than the gaged streamflow. The probable reasons for this are that the simulated streamflow does not include the effects of (1) tributary inflow, (2) canal return, and (3) direct runoff to the stream. All of these possibilities are most prevalent during periods of high flow in association with periods of intense precipitation.

In general, the simulated water levels and streamflow compare favorably with their measured counterparts. The comparisons shown in figures 32-34 indicate that the transient model is sufficiently calibrated to predict, with reasonable accuracy, hydrologic responses to hypothetical conditions of streamflow, pumpage, and precipitation. In subsequent sections of this report, water levels and streamflow simulated with the calibrated 1970 79 transient model are compared against water levels and streamflow resulting from simulations of hypothetical conditions. 


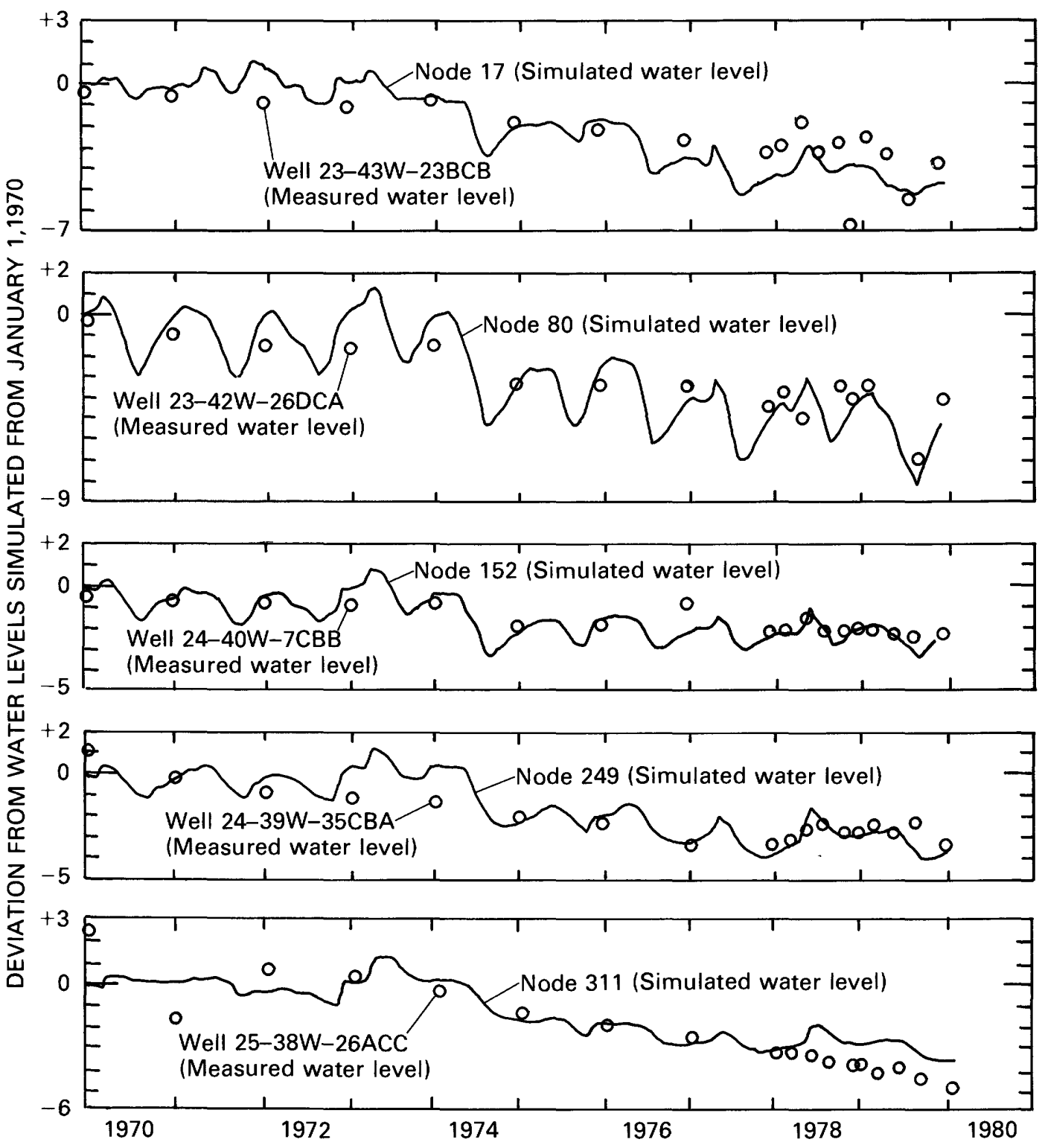

Figure 32. Measured and simulated water levels at selected sites, 1970-79.

\section{Water Budget}

In addition to simulating water levels and streamflow, the calibrated steady-state model and the 1970-79 transient model provide simulated hydrologic fluxes. A tabulation of these fluxes for 1970-74 and 197579 conditions is presented in table 2.

Additionally, simulated monthly rates during 1970 79 are shown for precipitation, irrigation, and actual evapotranspiration in figure 36; for deep percolation and pumpage in figure 37 ; and for net stream-aquifer leakage, net boundary flow, and ground-water evapotranspiration in figure 38. Simulated monthly rates during 1970-79 also are shown for stream-aquifer leakage in four reaches of the Arkansas River in figure 39.

The simulated water budget shows that the ratio of river loss to river gain increased from about 3 to 1 

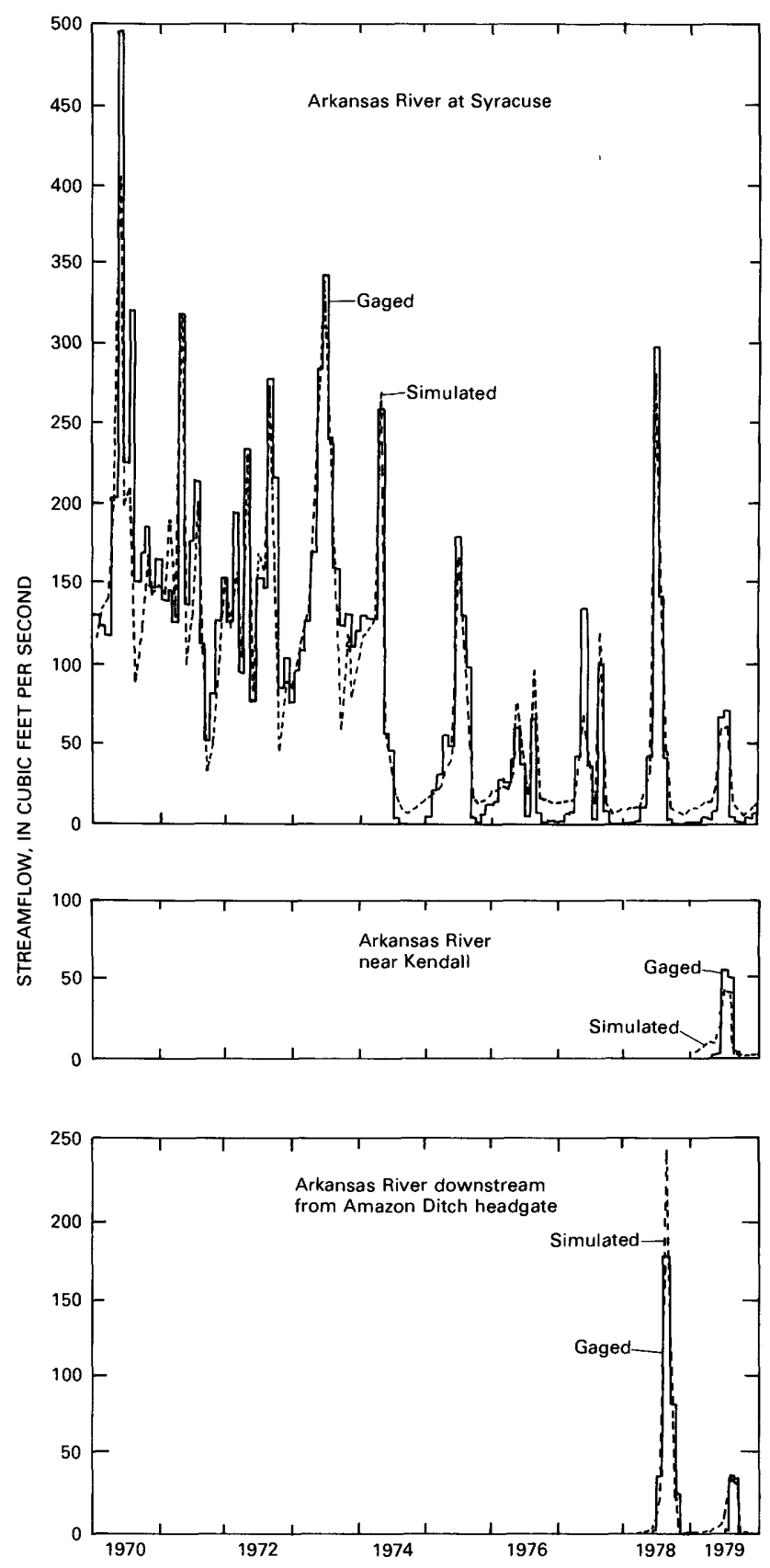

Figure 33. Gaged and simulated mean monthly discharge of Arkansas River at Syracuse (1970-79), near Kendall (1979), and downstream from Amazon Ditch headgate (1978-79).

during 1970-74 to about 20 to 1 during $1975-79$ in response to the substantial decrease in incoming streamflow. Because pumpage during 1975-79 was nearly double the pumpage during 1970-74, the increase in ground water applied as irrigation resulted in an increase in deep percolation of about 40 percent. Also, deep percolation increased from about 22 percent of incident water (irrigation plus precipitation) to about 26 percent. In accord with the declining water levels, both subsurface lateral inflow and outflow decreased slightly, and ground-water evapotranspiration decreased by one-third. Simulation shows that aquifer storage decreased slightly more than 1,000 acre- $\mathrm{ft} / \mathrm{yr}$ between the opening and closing of the 1970 decade.

\section{Hypothetical Situations}

The predictive capabilities of the calibrated model permit hypothetical conditions to be explored by simply changing data input to emulate the situations desired. A series of model simulations were made to evaluate past and future conditions of hypothetical hydrology. 1970-79

A model simulation was made to test the effect on the water shortage during the 1970's due to the decreased incoming streamflow during 1970-79. The streamflow input for this simulation was the mean monthly Arkansas River discharge gaged near Coolidge between 1951-69. All other input was identical to that for the calibrated 1970-79 transient model and, therefore, represented actual conditions. The effect of this simulation on water levels is shown in figure 40 , where simulated levels are compared to those simulated with the calibrated 1970-79 transient model. The effect on streamflow is shown in figure 41 , where the differences between streamflow simulated here and that simulated with the calibrated 1970-79 transient model are displayed for Syracuse, Kendall, and downstream from the Amazon Ditch headgate.

The data in figures 40 and 41 show substantial differences between simulated 1970-79 actual conditions and those resulting from average 1951-69 incoming streamflow. Using pre-1970 input streamflow, the model simulates water levels 2 to 5 feet higher and streamflow as much as $500 \mathrm{ft}^{3} / \mathrm{s}$ greater through 1979 . The resulting differences show stream-aquifer conditions to be greatly dependent on the magnitude and duration of upstream river flow.

A second model simulation was made to test the effect on the water shortage during the 1970's due to the substantial increase in pumpage between 1974 and 1979 (fig. 23). Although the pumpage in this simulation was the same through 1973 as that in the calibrated 1970-79 transient model, only those wells that were pumped prior to 1974 were simulated to pump between 1974-79. All other input was identical to that for the calibrated 1970-79 transient model and, therefore, represented actual conditions. The effects of this simulation on water levels are shown in figure 42 , where simulated levels are compared to those simulated with the calibrated 1970-79 transient model. The effect on streamflow is shown in figure 43 , where the differences between streamflow simulated here and that simulated with the calibrated 1970-79 transient model are displayed for Syracuse, Kendall, and downstream from the Amazon Ditch headgate.

Simulated differences resulting from model simulations using actual and hypothetical pumpage (figs. 42 and 


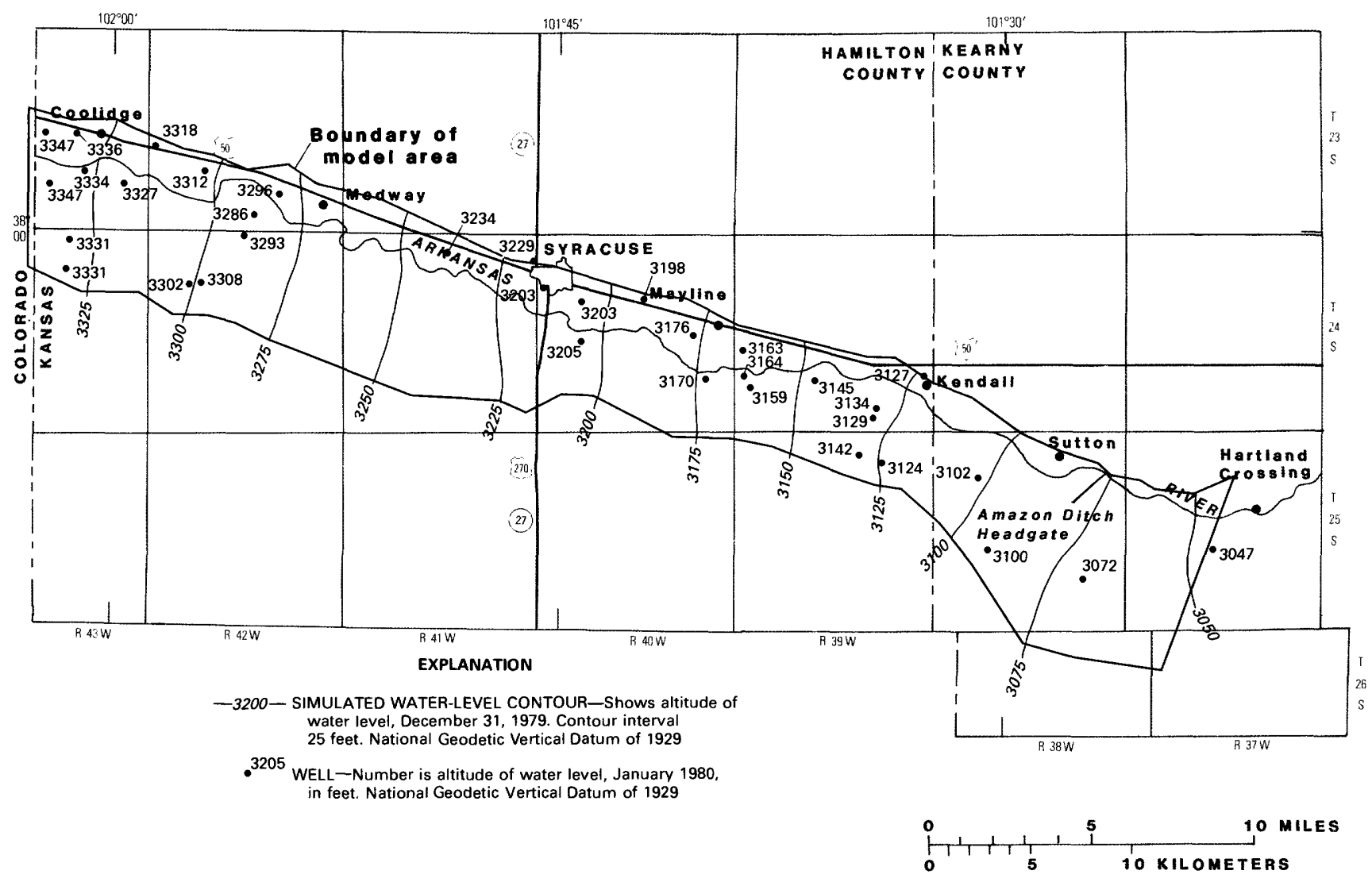

Figure 34. Comparison of water-level contours simulated for December 31, 1979, and water-level altitudes measured during January 1980 within model area.

Table 2. Simulated water budget for Arkansas River alluvium between Colorado-Kansas State line and Bear Creek Fault zone, Kearny and Hamilton Counties, Kansas [Values are given in acre-feet per year]

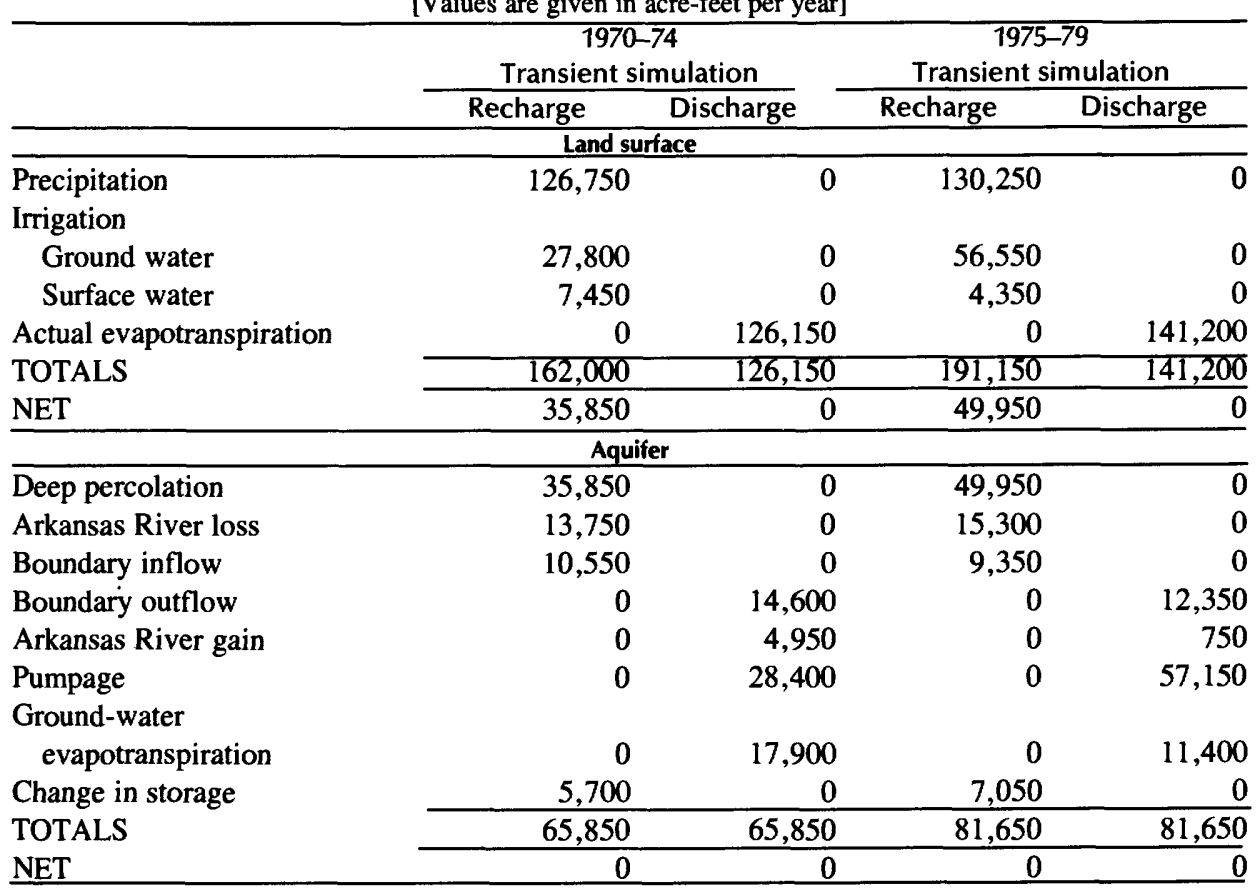




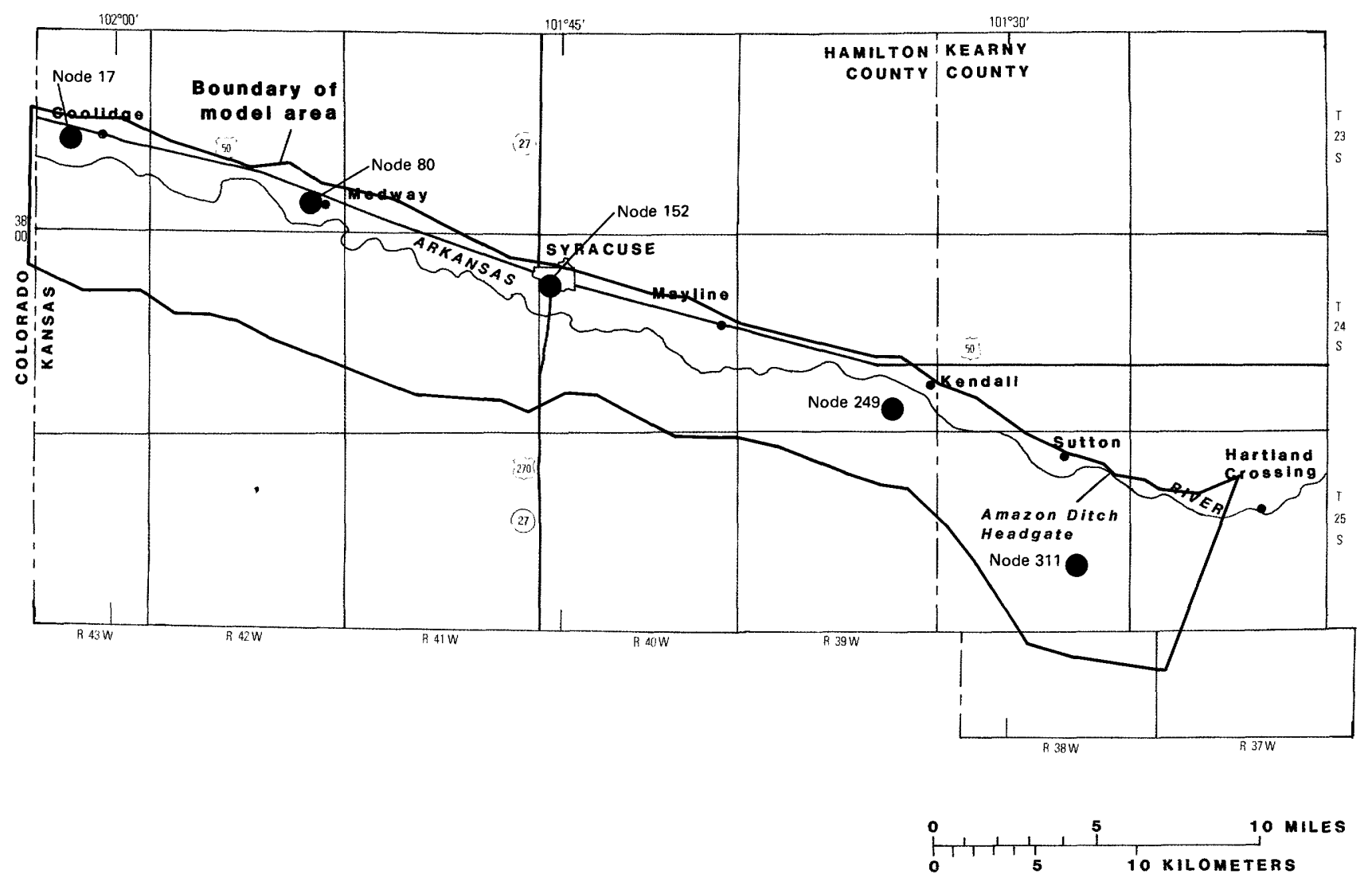

Figure 35. Location of finite-element nodes for which water levels are simulated for comparison with measured levels.

43) are not as large as those resulting from different incoming streamflow (figs. 41 and 42). The detrimental effects of pumpage increases are offset somewhat because the additional pumpage is used for irrigation, helping to satisfy consumptive-use demands and producing additional recharge.

A third model simulation was made to test the direct effects of receiving less than average 1951-69 precipitation during 9 of the 10 years between 1970-79. The precipitation input for this simulation was the mean monthly 1951-69 precipitation at Syracuse. All other input was identical to that for the calibrated 1970-79 transient model and, therefore, represented actual conditions. The effect of this simulation on water levels is shown in figure 44 , where simulated levels are compared to those simulated with the calibrated 1970-79 transient model. The effect on streamflow is shown in figure 45 , where the differences between streamflow simulated here and that simulated with the calibrated 1970-79 transient model are displayed for Syracuse, Kendall, and downstream from the Amazon Ditch.

This third simulation produced generally lower water levels and streamflow than those obtained using the actual distribution of 1970-79 monthly precipitation in the

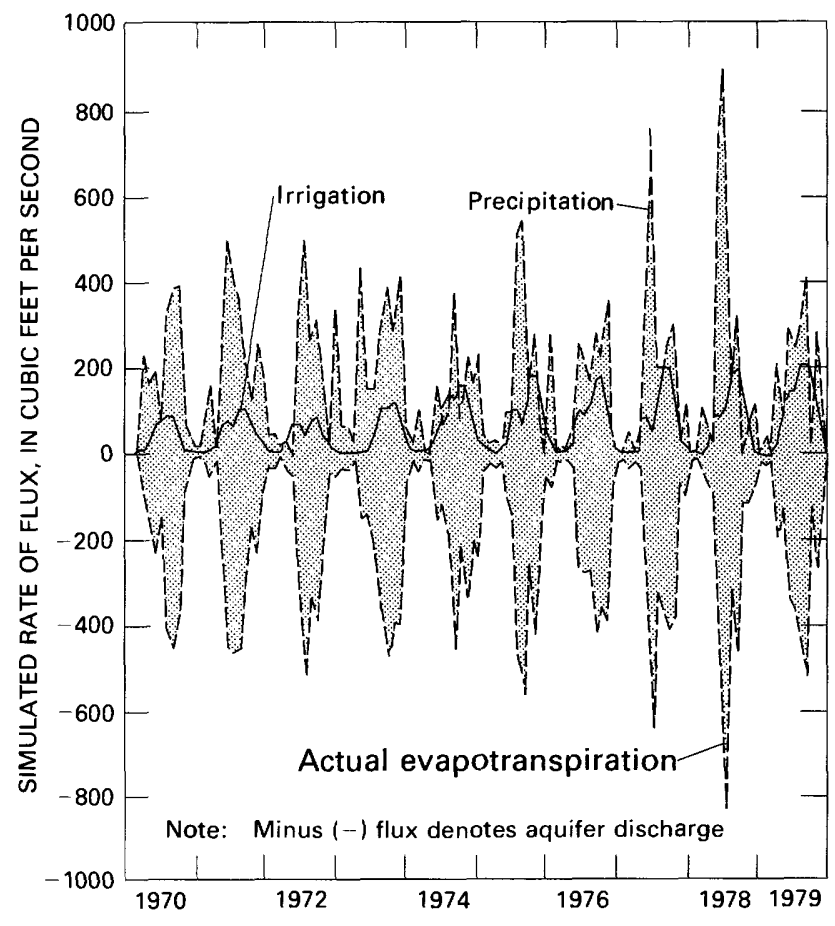

Figure 36. Simulated monthly rates of precipitation, irrigation, and actual evapotranspiration, 1970-79. 
calibrated model. The divergent water-level and streamflow responses shown in figures 44 and 45 indicate that-despite the annual precipitation shortages during the 1970's-_enough months received greater than normal precipitation and recharge to offset the direct effects of having less recharge during the less than normal months.

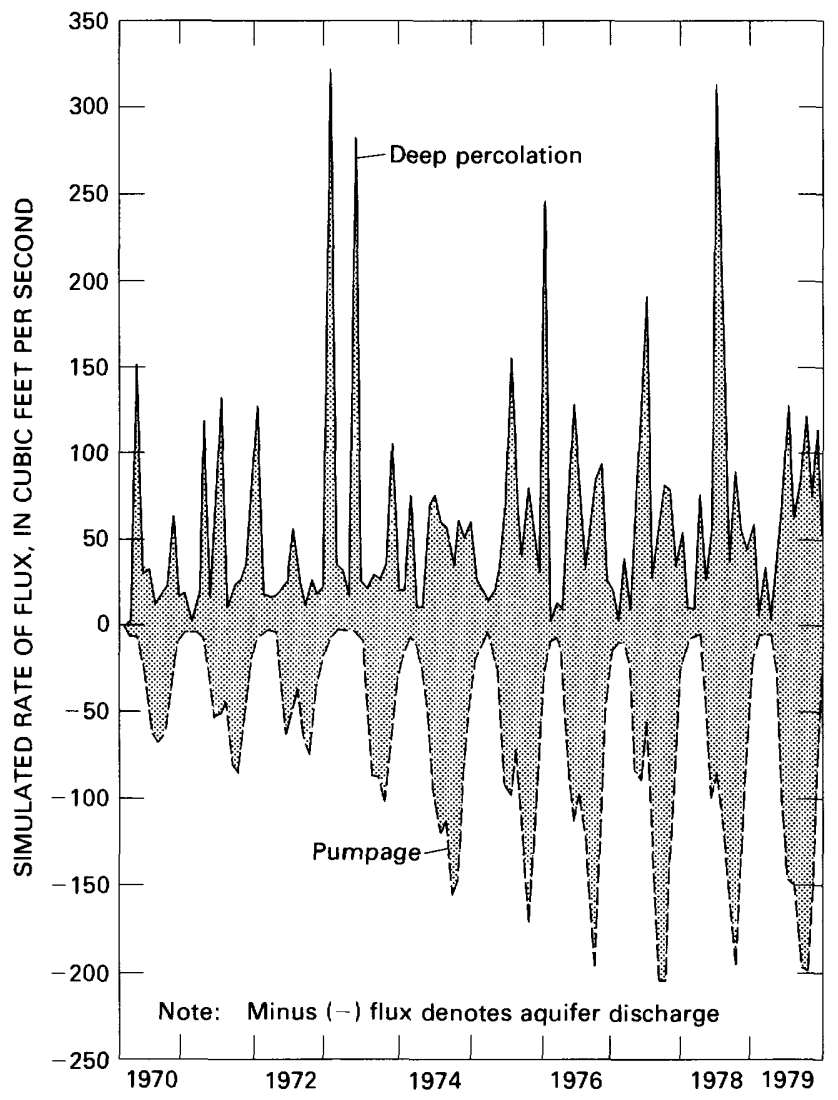

Figure 37. Simulated monthly rates of deep percolation and pumpage, 1970-79.

Although the precipitation during most summer months during 1970-79 was much less than the mean 1951-69 precipitation during many spring months was more than the mean. The drought of the 1970's was due to severe precipitation deficiencies during July and August of most years. Model results show the direct, independent impact on water levels and streambed flux to be limited because--even under mean conditions-the relatively large consumptive-use demands of July and August leave little residual for deep percolation. The divergent responses shown in figures 44 and 45 are due mainly to frequent occurrences of precipitation that were much greater than the monthly mean during March, May, and June of 1970-79. During these months, the demands of consumptive use were relatively small and the additional water (compared to mean conditions) resulted in additional deep percolation. Although precipitation was deficient during the summers of 1970-79, the detrimental effect of the drought on recharge was, apparently, minor.

It must be acknowledged, however, that this simulation (results shown in figures 44 and 45) explores only the independent effects of more or less deep percolation, depending upon differences between long-term mean monthly precipitation and that actually received. To ignore the possibility of associated, additional effects due to human or system response might cause misleading conclusions. For example, probable side benefits of having at least average precipitation that could result in less need for pumpage and canal diversion, were not explored in the simulation.

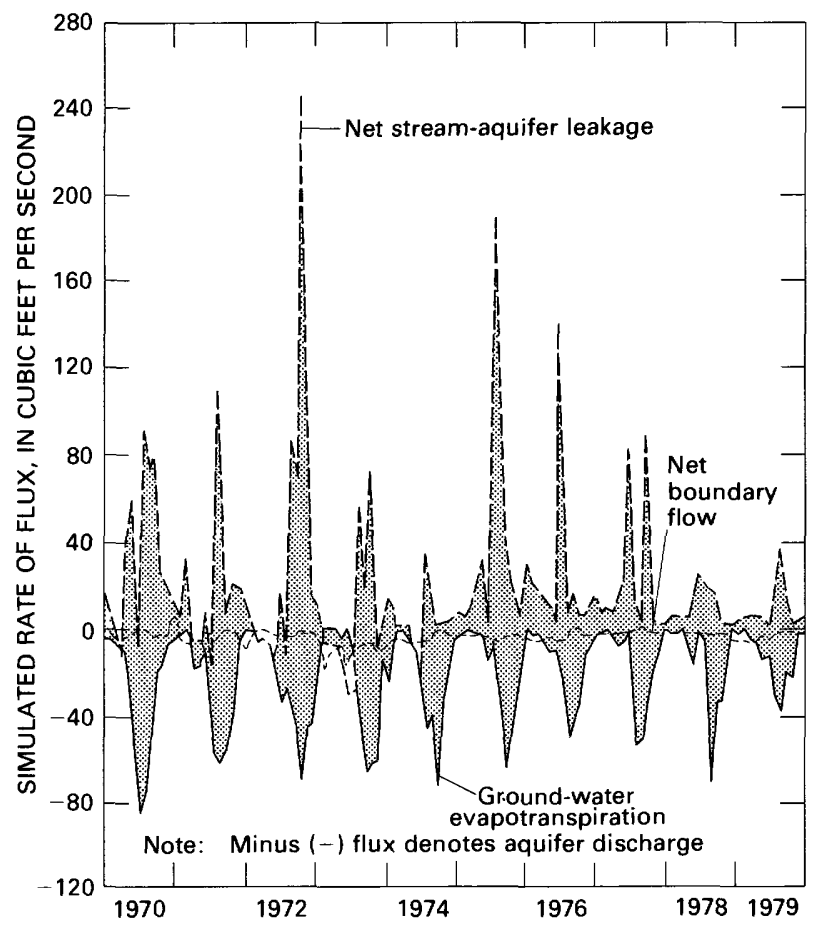

Figure 38. Simulated monthly rates of net streamaquifer leakage, net boundary flow, and ground-water evapotranspiration, 1970-79.

1980-82

Eight model simulations were made projecting hypothetical conditions of streamflow, pumpage, and precipitation from January 1980 through December 1982. For discussion herein, these projections are labeled 1 through 8. Hydrographs of water levels simulated at nodes 80 , 152 , and 249 (fig. 35) are used to illustrate aquifer response; likewise, stream response is shown for the Arkansas River at Syracuse, at Kendall, and downstream from the Amazon Ditch headgate. 

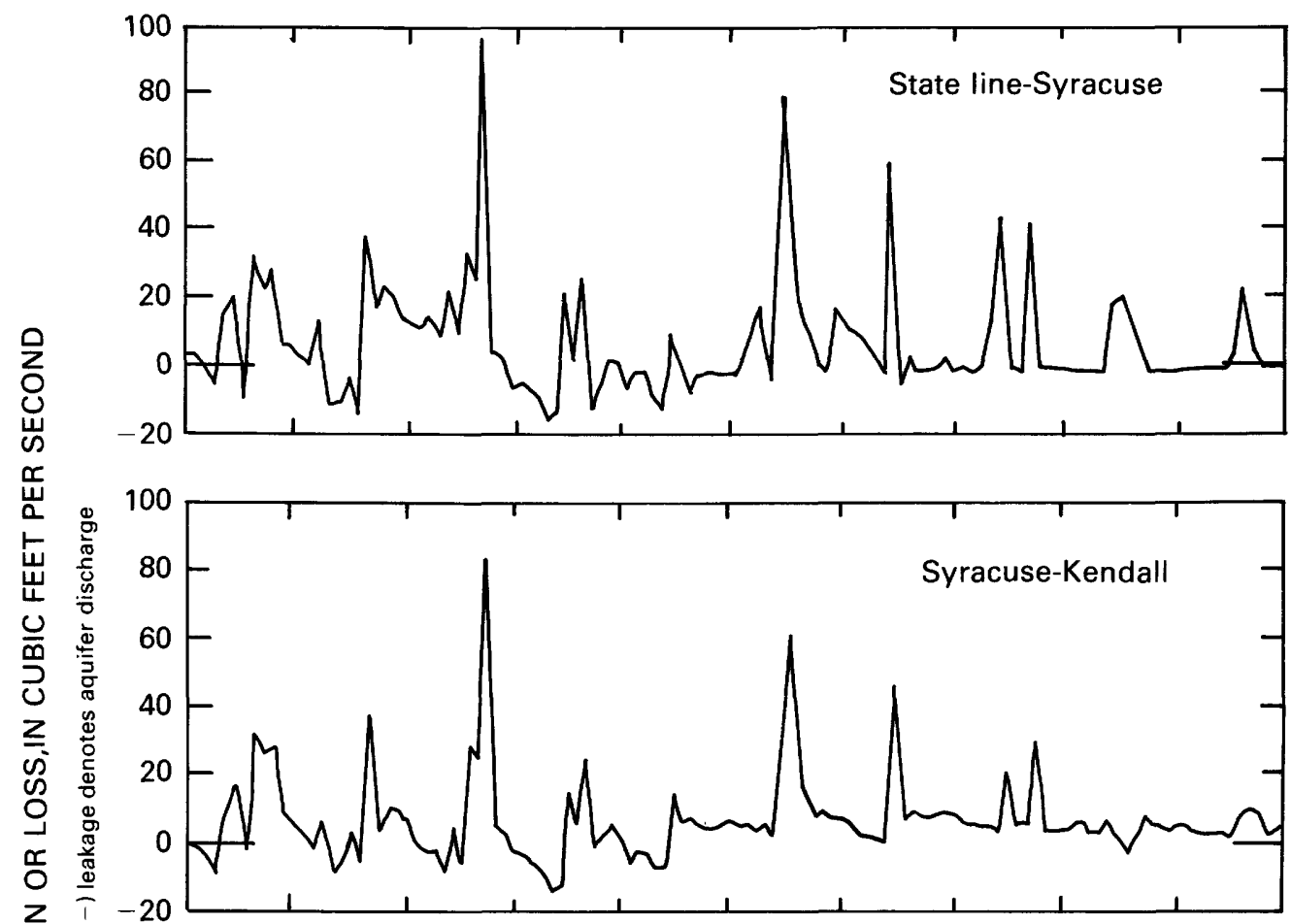

造

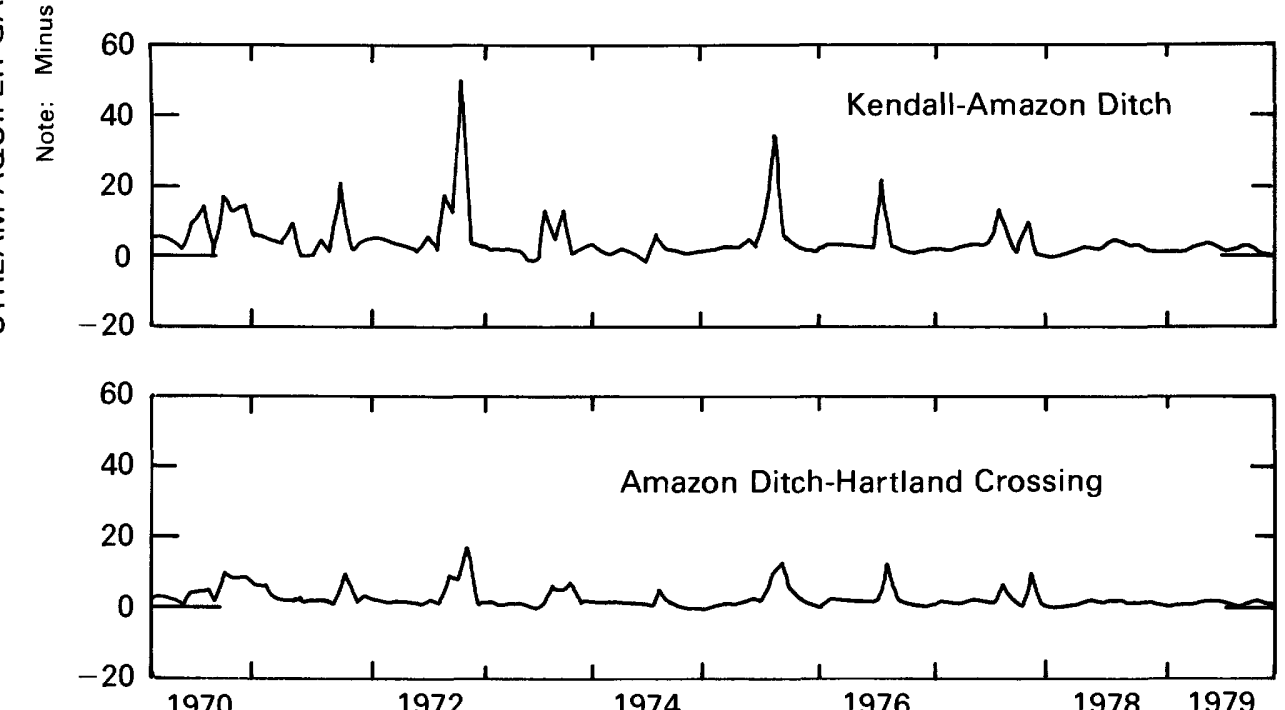

Figure 39. Simulated monthly rates of stream-aquifer leakage in four reaches of Arkansas River, 1970-79. 

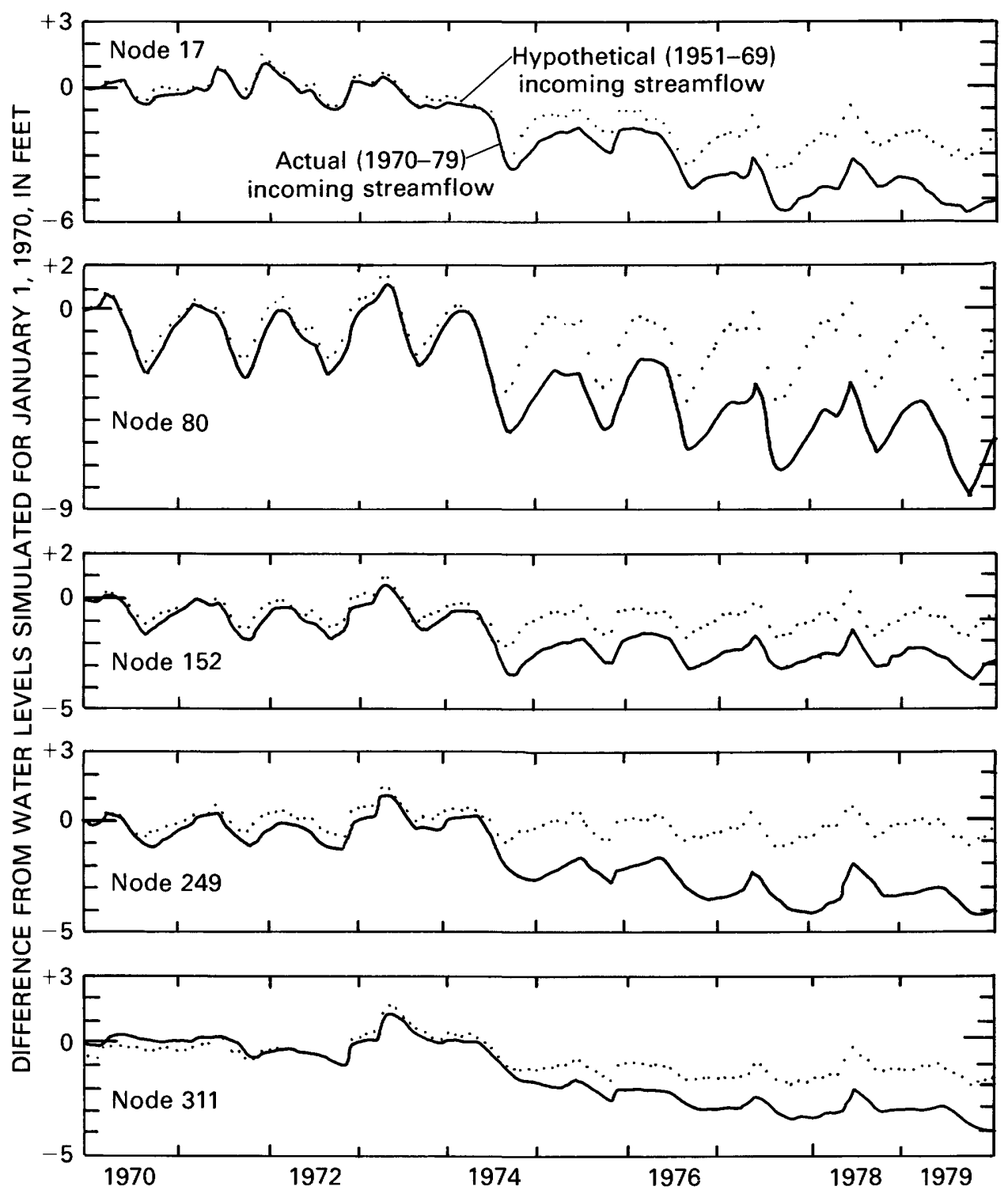

Figure 40. Comparison of simulated water levels at selected sites using hypothetical (1951-69) and actual (1970-79) rates of incoming streamflow. 


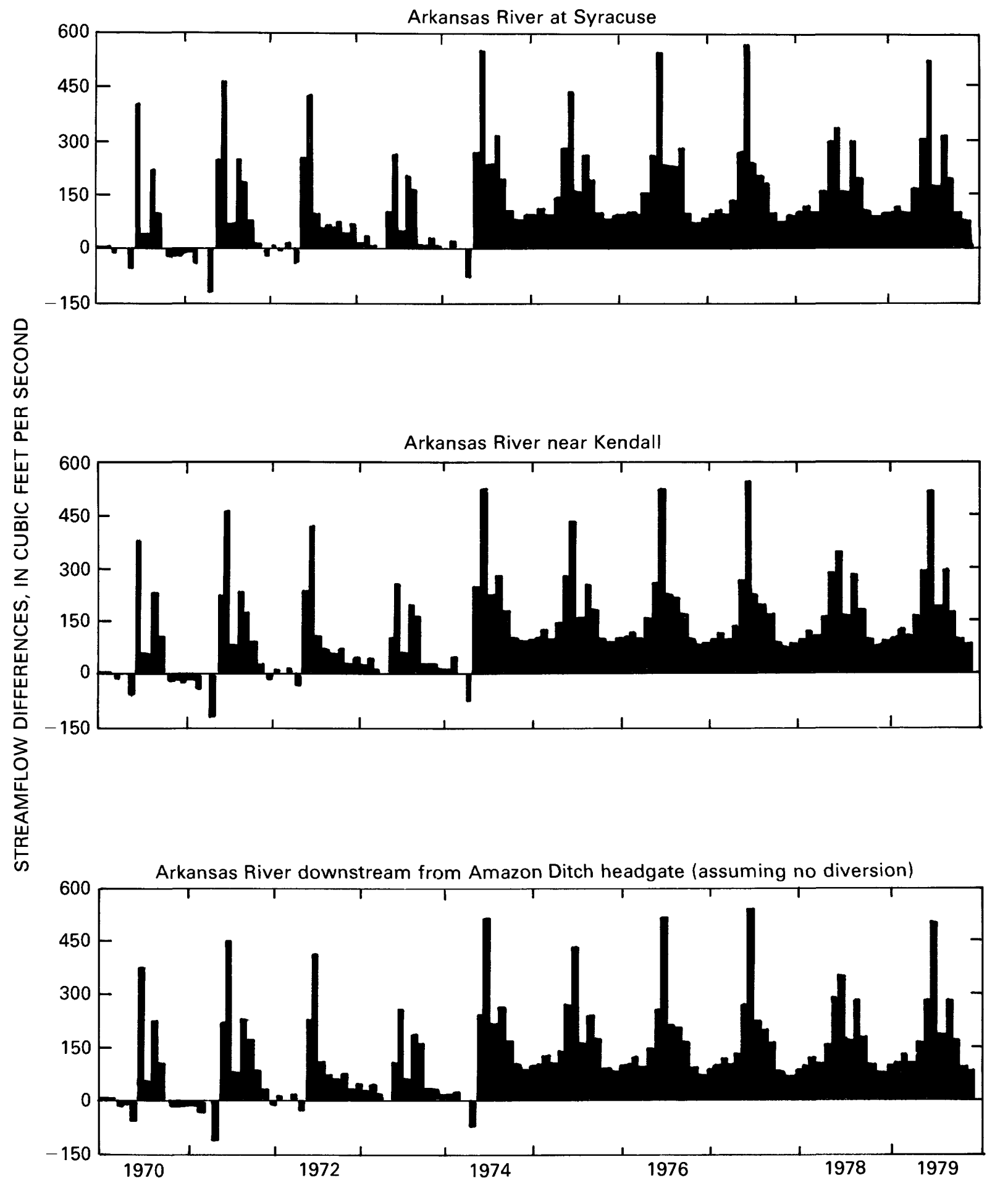

Figure 41. Differences between simulated streamflow at selected sites using relation of hypothetical (195169) to actual (1970-79) rates of incoming streamflow. 

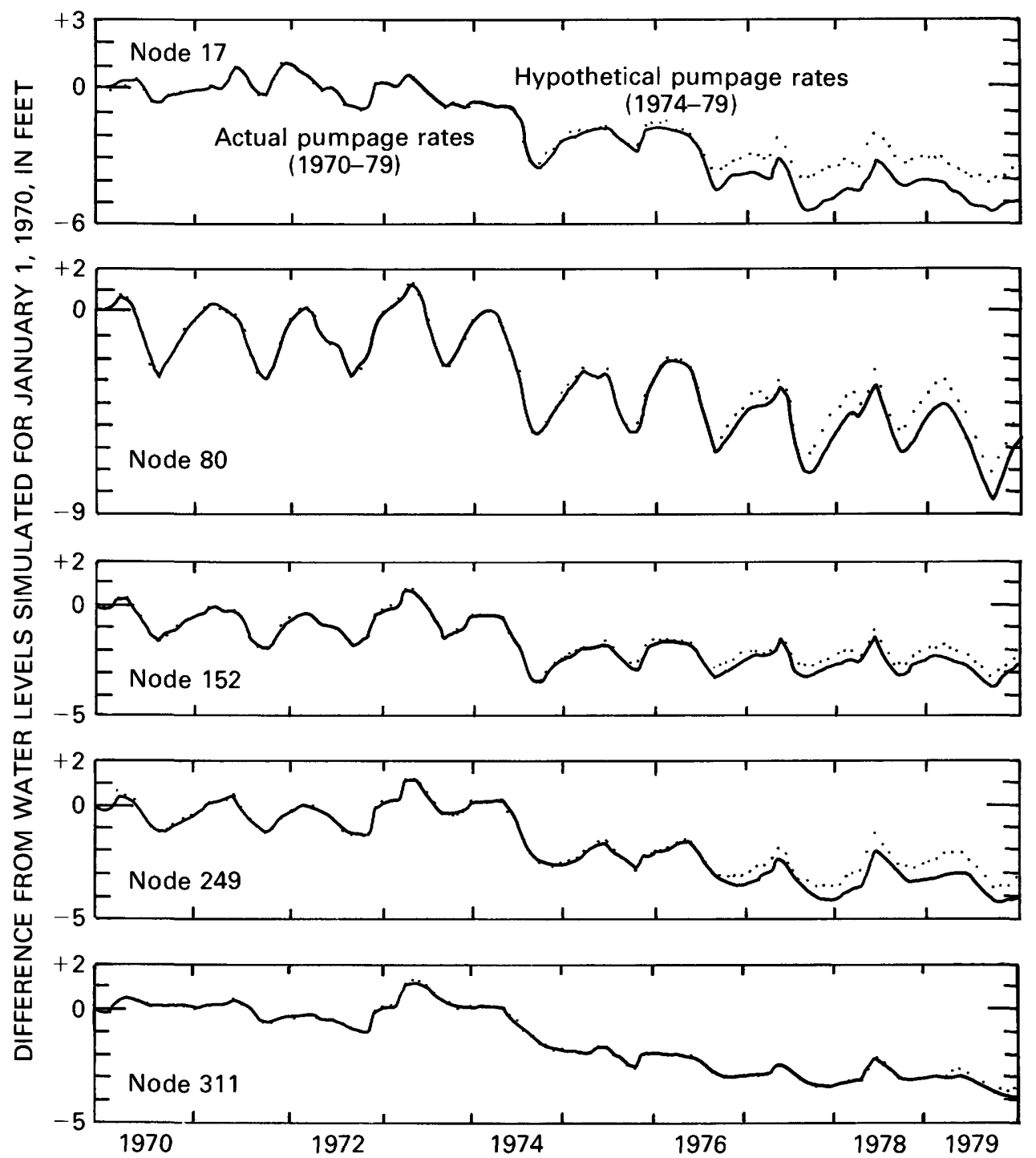

Figure 42. Comparison of simulated water levels at selected sites using hypothetical (1974-79) and actual (1970-79) rates of pumpage.

In projection 1, hydrologic conditions were simulated assuming a continuation of 1979 conditions of pumpage and incoming streamflow, normal (1941-70) precipitation, and consumptive-use demand based on normal temperatures. Projection 1 results are shown in figure 46. January water levels would decline an average of $0.7 \mathrm{ft} / \mathrm{yr}$ at node $80,0.3 \mathrm{ft} / \mathrm{yr}$ at node 152 , and $0.4 \mathrm{ft} / \mathrm{yr}$ at node 249; whereas, average monthly streamflow would remain relatively similar at similar times of the year at Syracuse, at Kendall, and downstream from the Amazon Ditch headgate.

Results of projection 1 are referenced henceforth as "continued 1979 conditions" and are shown in figures 47-50 for comparison with results of projections 2-8. Projections 2-8 explore the effects of differences from 1979 conditions. 

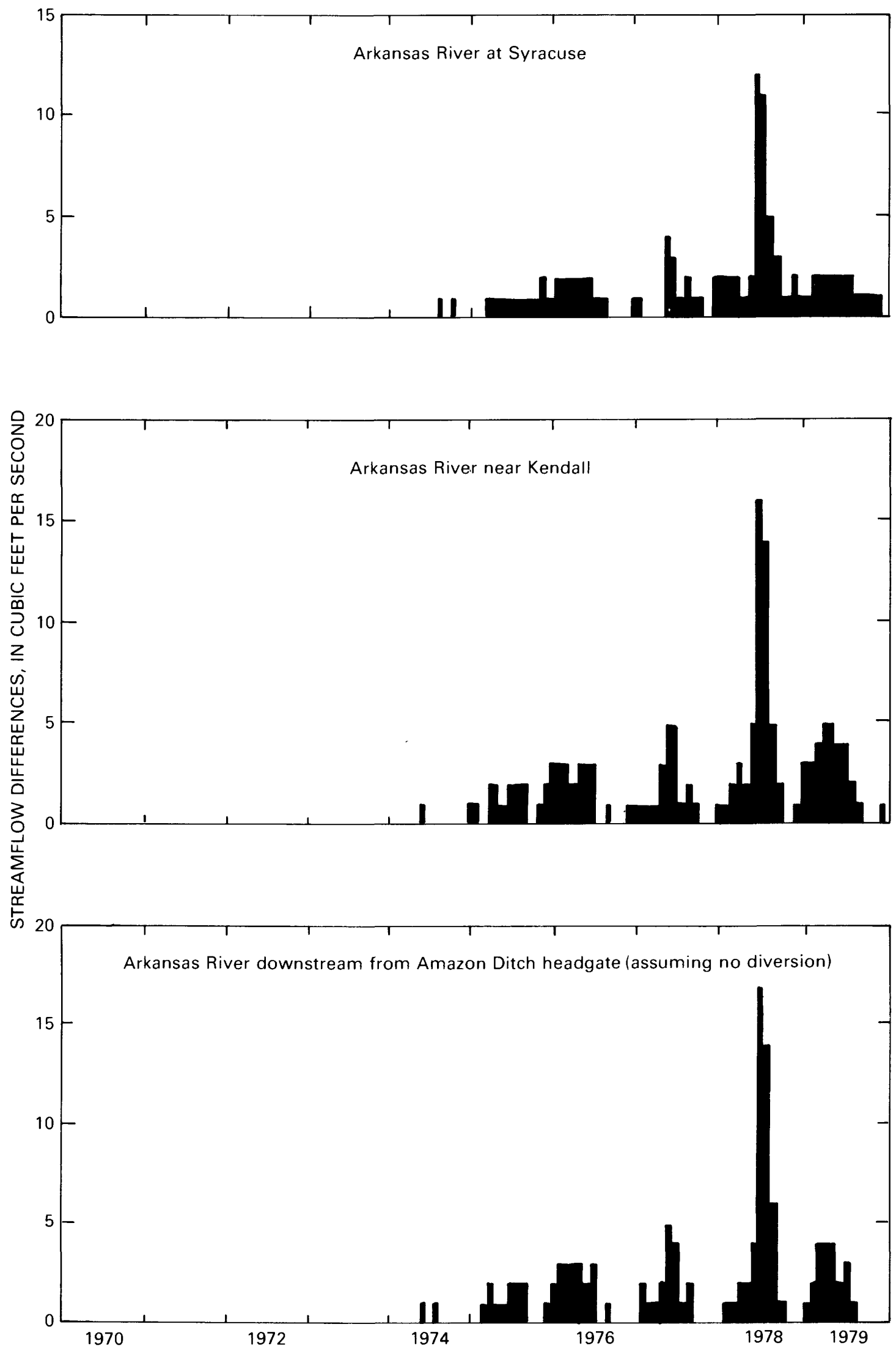

Figure 43. Differences between simulated streamflow at selected sites using relation of hypothetical (1974-79) to actual (1970-79) rates of pumpage. 


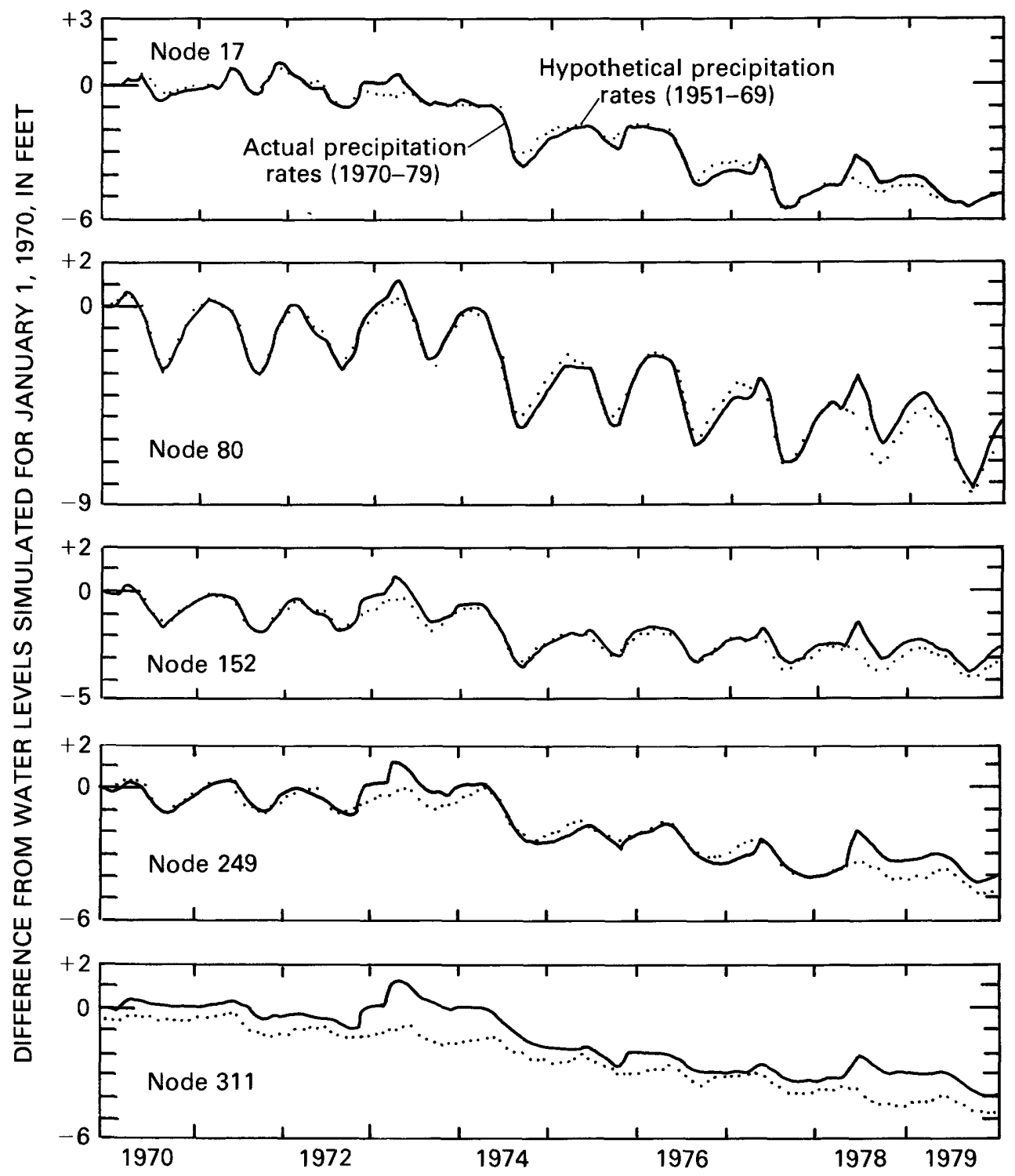

Figure 44. Comparison of simulated water levels at selected sites using hypothetical (1951-69) and actual (1970-79) rates of precipitation.

In projection 2 , hydrologic conditions were simulated assuming 1951-69 mean monthly rates of incoming streamflow. This projection cycled (repeated on annual basis) 1979 monthly rates of pumpage and normal precipitation. Results indicate (fig. 47) that January water levels would rise an average of $1.6 \mathrm{ft} / \mathrm{yr}$ at node $80,0.7 \mathrm{ft} / \mathrm{yr}$ at node 152 , and $1.2 \mathrm{ft} / \mathrm{yr}$ at node 249 . In accordance with the large increases (greater than 1979 rates) in incoming streamflow, substantial increases in streamflow (greater than that simulated under continued 1979 conditions) are shown for all downstream reaches of the river.

In projection 3 , hydrologic conditions were simu- lated assuming an increase in streamflow of 500 percent greater than 1979 rates. Such an increase would provide an average incoming streamflow of about $400 \mathrm{ft}^{3} / \mathrm{s}$ during June and July. This simulation cycled 1979 pumpage conditions and normal monthly precipitation. Results indicate (fig. 48) that January water levels would rise an average of $0.8 \mathrm{ft} / \mathrm{yr}$ at node $80,0.3 \mathrm{ft} / \mathrm{yr}$ at node 152 , and 0.6 $\mathrm{ft} / \mathrm{yr}$ at node 249 . Closely resembling the projected rates of incoming streamflow, simulated flows at Syracuse, at Kendall, and downstream from the Amazon Ditch headgate would be nearly five times those simulated under continued 1979 conditions. 


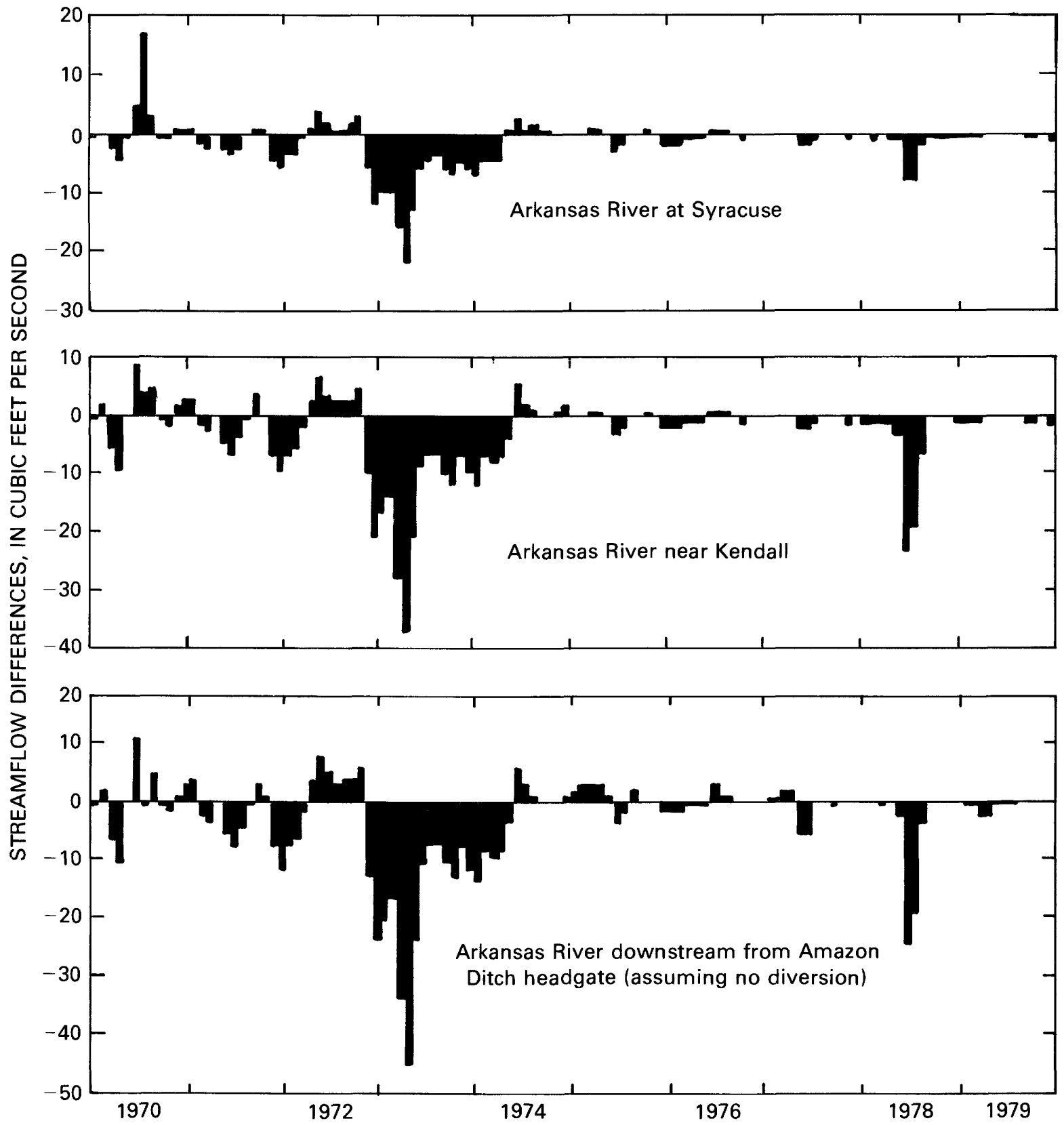

Figure 45. Differences between simulated streamflow at selected sites using relation of hypothetical (195169) to actual (1970-79) rates of precipitation.

In projection 4, the input duplicated that for projection 3, except that incoming streamflow was 50 percent less than during 1979. Results of projection 4 (fig. 48) indicate that January water levels would decline an average of $1.0 \mathrm{ft} / \mathrm{yr}$ at node $80,0.3 \mathrm{ft} / \mathrm{yr}$ at node 152 , and $0.8 \mathrm{ft} / \mathrm{yr}$ at node 249. Simulated streamflow would be about one-half that simulated under continued 1979 conditions.

In projection 5 , hydrologic conditions were simulated assuming an increase in pumpage of 50 percent greater than 1979 rates, while 1979 pumpage locations were maintained. This simulation cycled 1979 conditions of incoming streamflow and normal monthly precipitation. Results indicate (fig. 49) that January water levels would decline an average of $0.8 \mathrm{ft} / \mathrm{yr}$ at node $80,0.4 \mathrm{ft} / \mathrm{yr}$ at node 152 , and $0.5 \mathrm{ft} / \mathrm{yr}$ at node 249 . Simulated streamflow at Syracuse, at Kendall, and downstream from the Amazon Ditch headgate would be slightly less than that simulated under continued 1979 conditions. 

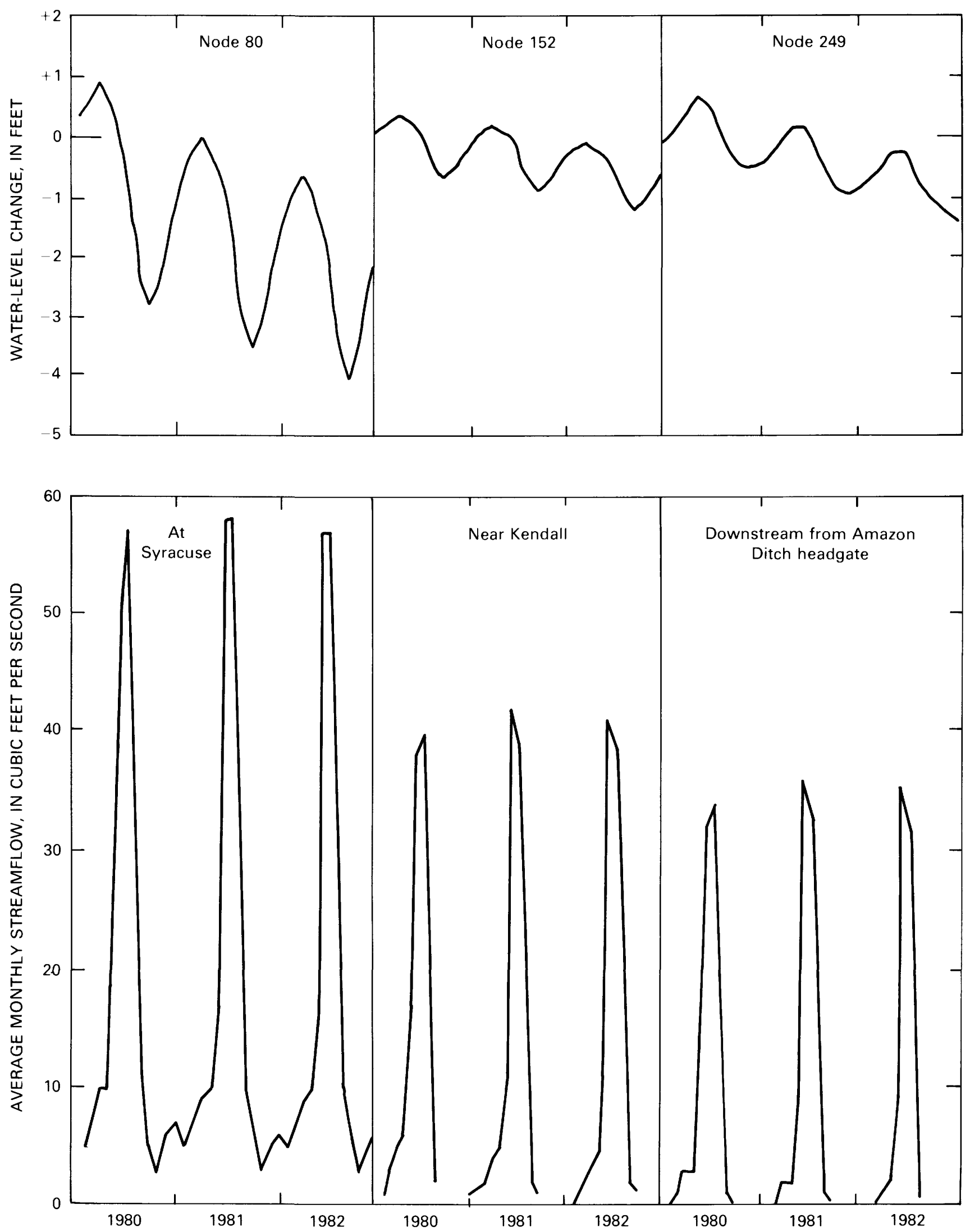

Figure 46. Simulated water levels and average monthly streamflow during $1980-82$ at selected sites using normal (1941-70) precipitation, 1979 pumpage, and incoming streamflow at 1979 rate (projection 1). 

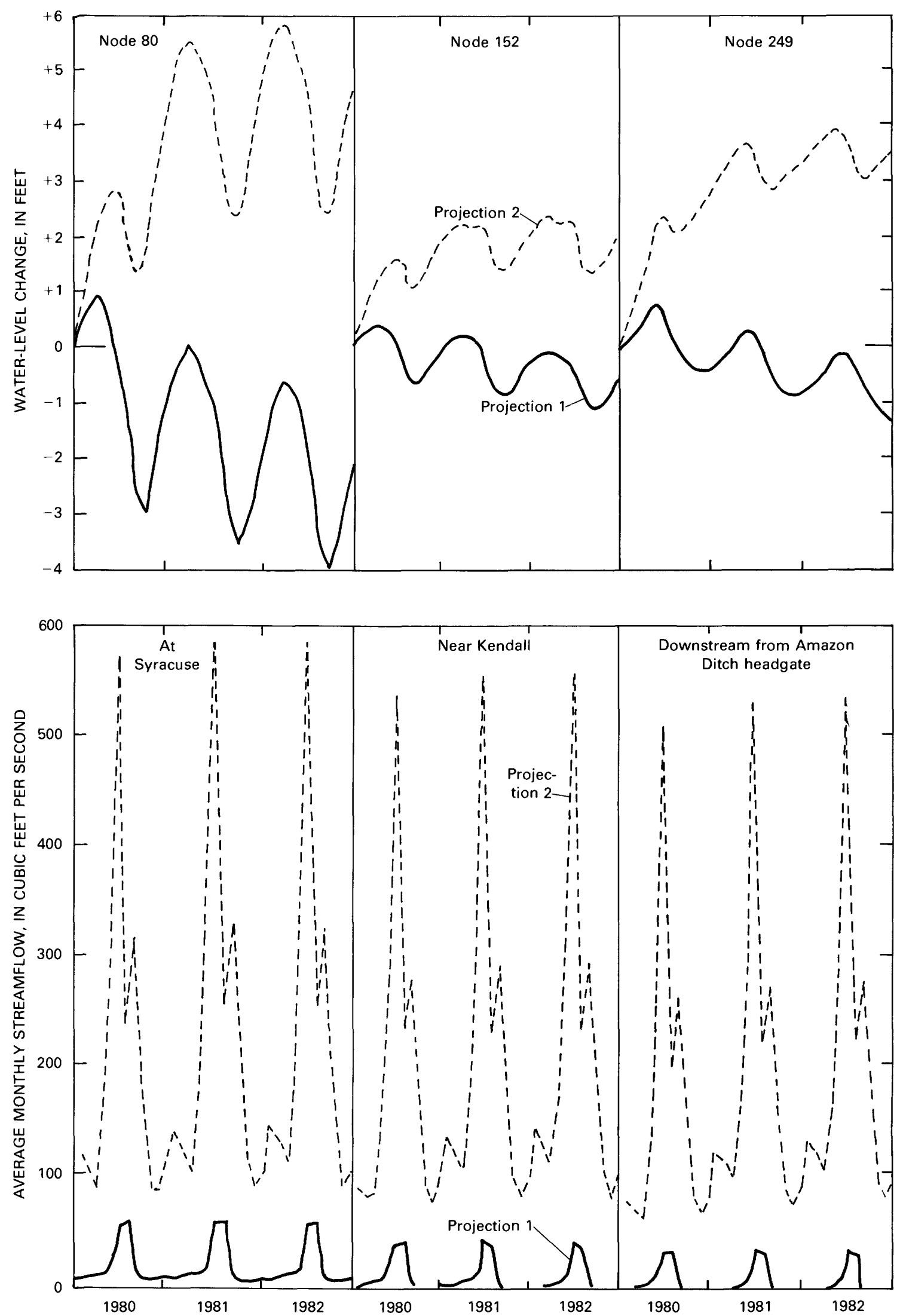

Figure 47. Simulated water levels and average monthly streamflow during 1980-82 at selected sites using normal (1941-70) precipitation, 1979 pumpage, and incoming streamflow at 1979 rate (projection 1) and 1951-69 rate (projection 2). 

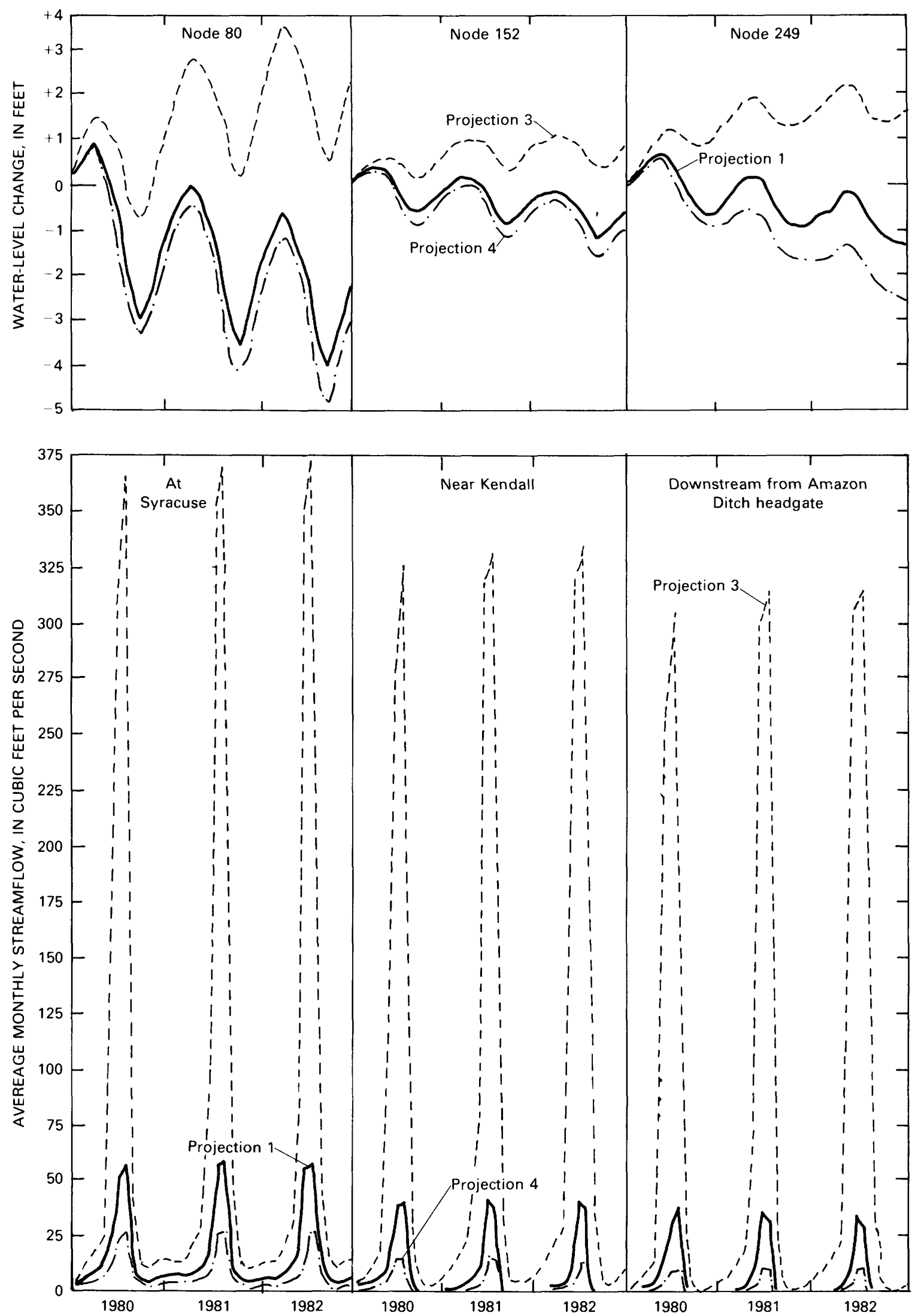

Figure 48. Simulated water levels and average monthly streamflow during $1980-82$ at selected sites using normal (1941-70) precipitation, 1979 pumpage, and incoming streamflow at 1979 rate (projection 1), at 500-percent increase (projection 3), and at 50-percent decrease (projection 4). 

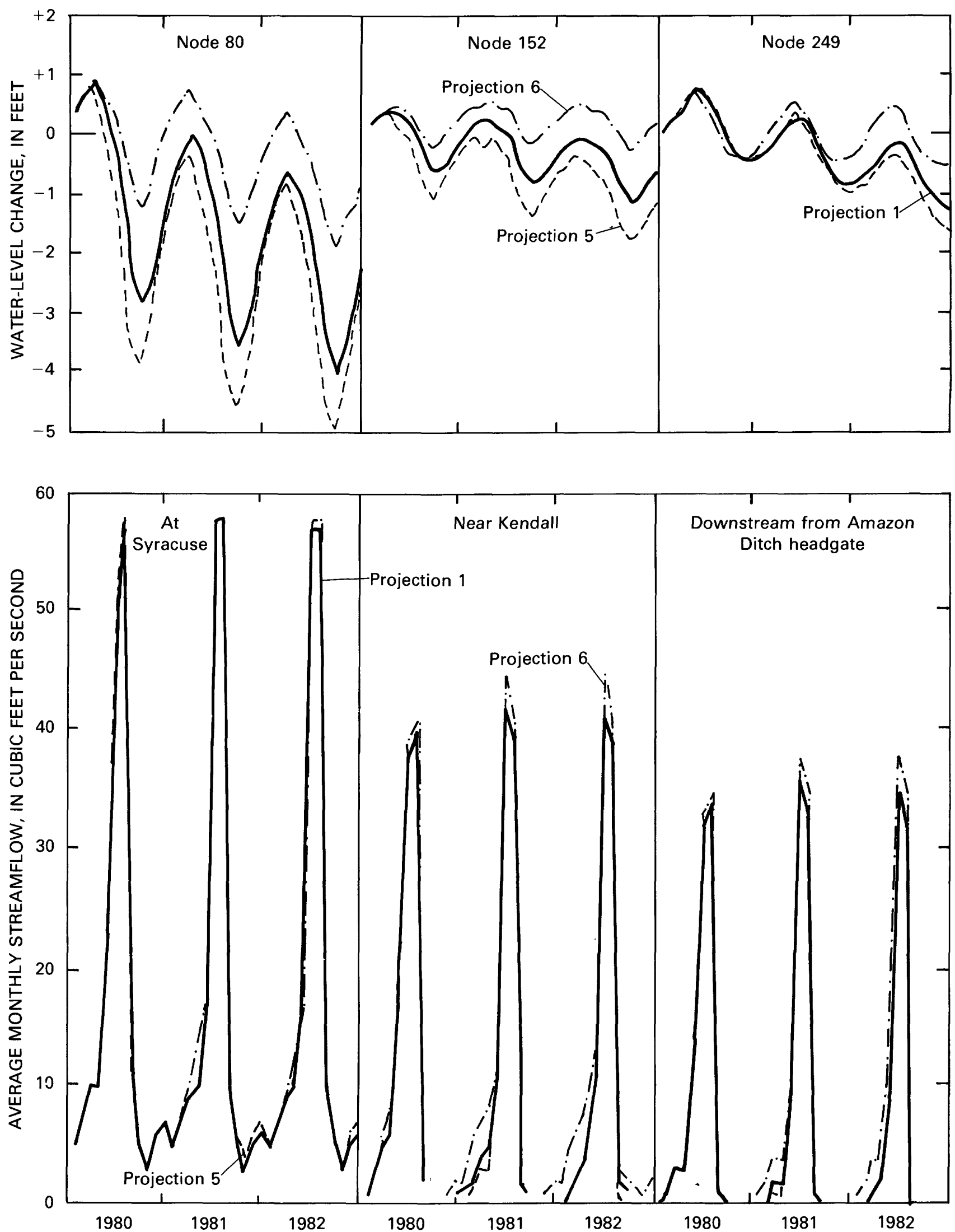

Figure 49. Simulated water levels and average monthly streamflow during $1980-82$ at selected sites using normal (1941-70) precipitation, incoming streamflow at 1979 rate, and pumpage at 1979 rate (projection 1), at 50-percent increase (projection 5), and at 50-percent decrease (projection 6). 
In projection 6, the input duplicated projection 5's input, except that pumpage was 50 percent of that during 1979. Results of projection 6 (fig. 49) indicate that water levels would change an average of $-0.3 \mathrm{ft} / \mathrm{yr}$ at node 80 , $+0.1 \mathrm{ft} / \mathrm{yr}$ at node 152 , and $-0.1 \mathrm{ft} / \mathrm{yr}$ at node 249 , (negative sign indicates decline). Simulated streamflow would be slightly more than that simulated under continued 1979 conditions.

In projection 7 , hydrologic conditions were simulated assuming an increase in precipitation of 25 percent greater than monthly normal (1941-70) conditions. This simulation provided 21.08 inches of annual precipitation for 1980-82 and cycled 1979 conditions of incoming streamflow and pumpage. Results indicate (fig. 50) that January water levels would change an average of -0.1 $\mathrm{ft} / \mathrm{yr}$ at node $80,+0.1 \mathrm{ft} / \mathrm{yr}$ at node 152 , and $+0.3 \mathrm{ft} / \mathrm{yr}$ at node 249. Although simulated streamflow at Syracuse, at Kendall, and downstream from the Amazon Ditch headgate would exceed that simulated under continued 1979 conditions (using normal precipitation), the increase generally would be less than 15 percent.

In projection 8 , the input duplicated projection 7's input, except that precipitation was 25 percent less than monthly normal conditions. Results of projection 8 (fig. 50 ) indicate that January water levels would decline an average of $1.3 \mathrm{ft} / \mathrm{yr}$ at node $80,0.5 \mathrm{ft} / \mathrm{yr}$ at node 152 , and $1.0 \mathrm{ft} / \mathrm{yr}$ at node 249 . Simulated streamflow would be about 5 percent less than that simulated under continued 1979 conditions.

\section{Sensitivity Tests}

There is always some uncertainty about the accuracy of model calibration. The importance of calibration error associated with different input parameters can be evaluated through sensitivity tests with the parameters of interest. Sensitivity of the Arkansas River valley model to possible errors in the calibration was tested by rerunning the 1970-79 transient model with the distributions of hydraulic conductivity, specific yield, and streambed leakance independently varied by 50 percent greater than and less than their respective calibrated values. Differences between results with the calibrated input and those with the varied input illustrate the range in simulated response associated with what is believed to be the maximum possibility for error in the definition of each parameter.

The sensitivity of simulated aquifer response to ranges in parameter definition are shown by hydrographs for node 80. Similarly, a variance diagram for the Arkansas River at Syracuse shows streamflow sensitivity; differences between results with the calibrated and varied input are shown as differences from a horizontal (zero difference) line.
Model sensitivity to variance in hydraulic conductivity is shown in figure 51 , to specific yield in figure 52 , and to streambed leakance in figure 53. The data in these illustrations indicate that simulated water levels are more sensitive to decreases in the magnitude of all parameters tested than to increases. In all instances, the decreases generally cause lower water levels than those obtained with the calibrated input, while the increases generally cause higher water levels. The data in figures 51-53 show streamflow is most sensitive to changes in streambed leakance and least sensitive to changes in hydraulic conductivity. Owing to associated differences in the direction of gradient, decreases in leakance values cause greater streamflow during periods of high flow (stream-to-aquifer gradient) and less streamflow during periods of low flow (aquifer-to-stream gradient).

\section{SUMMARY}

The Arkansas River alluvium is the major source of water in central Hamilton and west-central Kearny Counties of southwestern Kansas. This aquifer, which is bounded at the base and on the north and south by relatively impermeable bedrock, underlies nearly 110,000 acres between the Colorado-Kansas State line and the Bear Creek Fault zone. Static water levels in the predominantly sand and gravel aquifer declined about 4 feet during 1970 79. During 1979, depths to water ranged from about 5 to 100 feet, and saturated thicknesses averaged about 50 feet. Specific yields in the aquifer average about 0.17 , and transmissivities range from about 8,000 to $80,000 \mathrm{ft}^{2} /$ d. Well yields range from about 100 to $3,000 \mathrm{gal} / \mathrm{min}$. During 1979, 160 irrigation and public-supply wells pumped nearly 65,000 acre-ft of water; contrastingly, during 1970, less than 20,000 acre-ft was pumped by fewer than 100 wells. Most pumpage is from the aquifer underlying the river bottomland between Syracuse and Kendall. Nearly one-third $(31,000$ acres $)$ of the alluvial surface is irrigated with wall pumpage and streamflow diversions from the Arkansas River.

The Arkansas River, which is about 20 feet wide, lies atop the alluvial fill. Gaged river inflow across the State line decreased about 60 percent from an average $232 \mathrm{ft}^{3} / \mathrm{s}$ during 1951-69 to an average $85 \mathrm{ft}^{3} / \mathrm{s}$ during 1970-79. As a result, downstream diversions also have decreased. Although the stream had been perennial, the channel downstream from Kendall has been dry most of the year since about 1975 . The area receives about 16 inches of precipitation per year; about 75 percent occurs between May and October. Precipitation during the 1970's at Syracuse averaged 14 percent, nearly 2.5 inches, less than normal. 

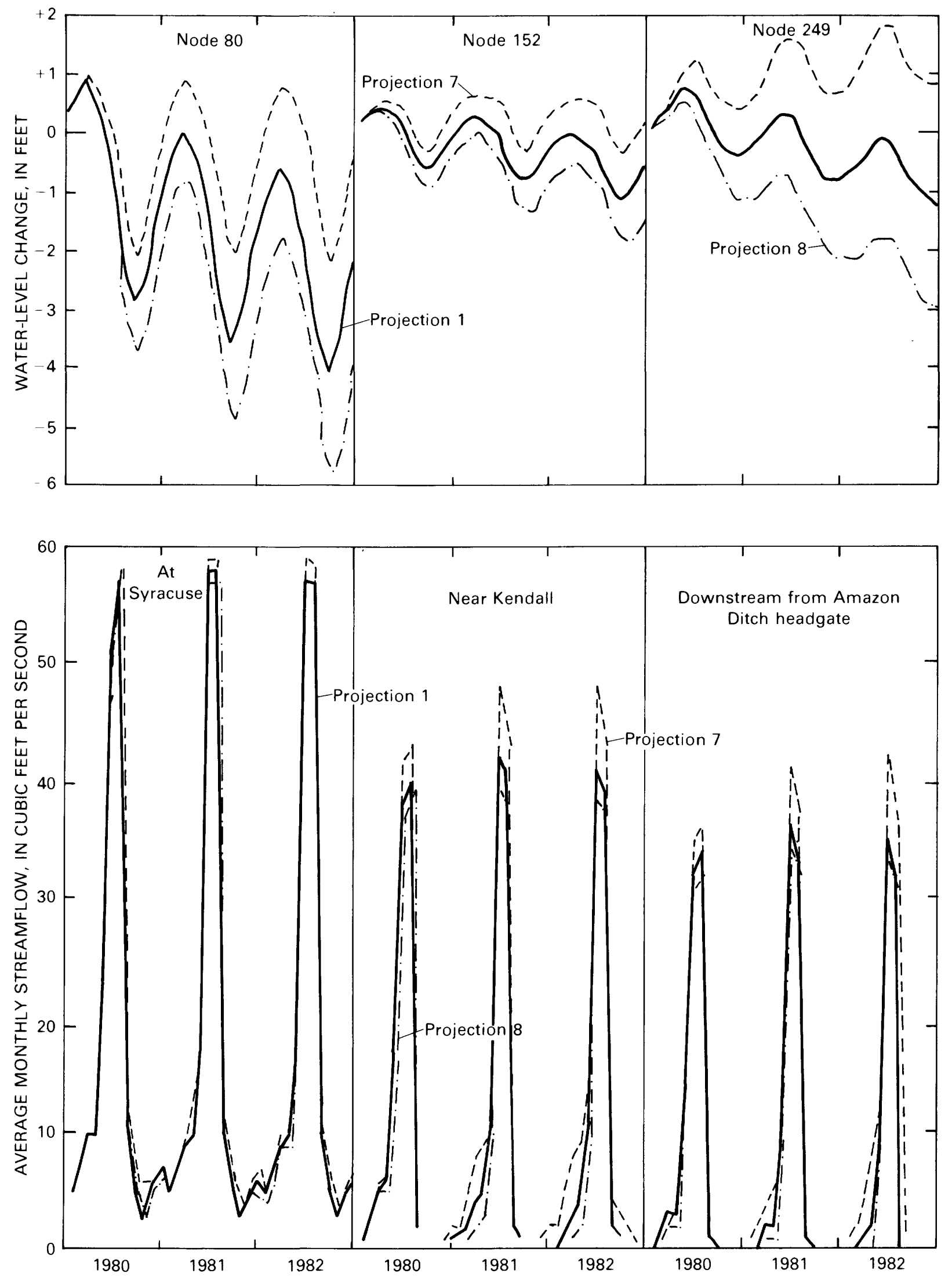

Figure 50. Simulated water levels and average monthly streamflow during 1980-82 at selected sites using 1979 pumpage, incoming streamflow at 1979 rate, and precipitation at normal 1941-70 rate (projection 1), at 25-percent increase (projection 7), and at 25-percent decrease (projection 8). 
A significant relationship exists among precipitation, streamflow, and ground-water levels. Highs and lows in water-level hydrographs generally are consistent with similar trends in precipitation and streamflow records. Hydrologic activity between 1951-69 was dominated by patterns of cyclic response to cyclic stress and relatively moderate fluctuations in recharge and discharge. Throughout those 19 years, about as much water entered the streamaquifer system as discharged from it-indicative of hydrologic equilibrium. About 1970, however, the system began to have prolonged streamflow reductions and water-level declines that have continued into the 1980's, indicating that discharge now exceeds recharge and equilibrium conditions no longer exist (fig. 54).

A computer model, based on a finite-element numerical technique, was calibrated to reproduce, with acceptable accuracy, the observed water level and streamflow responses to the unprecedented hydrologic stresses during the 1970's. By simulating water levels, streamflow, and a water budget, the transient model quantifies the streamaquifer system during 1970-79 and provides projections of possible future conditions.

Model simulation indicates that during 1975-79 the aquifer was recharged by:

1. Leakage from the river (about 15,000 ) acre-ft/yr),

2. Lateral, subsurface inflow across the State line $(9,000$ acre- $\mathrm{ft} / \mathrm{yr}$ ), and

3. Deep percolation of precipitation and irrigation water $(50,000 \mathrm{acre}-\mathrm{ft} / \mathrm{yr})$.

The alluvium was discharged by:

1. Lateral outflow across the Bear Creek Fault zone $(12,000 \mathrm{acre}-\mathrm{ft} / \mathrm{yr})$,

2. Leakage to the river $(1,000 \mathrm{acre}-\mathrm{ft} / \mathrm{yr})$,

3. Ground-water evapotranspiration $(11,000$ acre- $\mathrm{ft} / \mathrm{yr})$, and

4. Pumpage (57,000 acre-ft/yr).

Corresponding to the average decrease in storage of about 7,000 acre-ft/yr between 1975-79, water levels are presently declining nearly $0.5 \mathrm{ft} / \mathrm{yr}$. The model indicates that, in response to the doubling of pumpage and severe reductions in incoming streamflow between 1970 74 and 1975-79, deep percolation increased nearly 40 percent and the ratio of river loss to gain increased from less than 3 to 1 (1970-74) to about 20 to 1 (1975-79). Deep percolation increased from about 22 percent of incident water (irrigation plus precipitation) to about 26 percent. In accord with the declining water levels, both subsurface lateral inflow and outflow decreased slightly, and ground-water evapotranspiration decreased by one-third. Simulation shows that changes in aquifer storage decreased slightly more than 1,000 acre-ft/yr between the beginning and end of the 1970 decade.
Results of model experimentation with hypothetical 1970-79 conditions show that water levels and streamflow within the study area were more directly affected by the reductions in incoming streamflow (compared to 1951-69 average conditions) than by either the smaller than average amounts of annual precipitation or the increased pumpage during the 1970's. Simulation indicates that: (1) The effects of less recharge during periods of smaller than average amounts of precipitation were offset by more recharge during brief periods when precipitation was much greater than the mean monthly amount and (2) the effects of the increased pumpage were partly offset by increased recharge resulting from increased irrigation.

Model projections from 1980 to 1982 indicate that, under continued conditions of normal precipitation and 1979 rates of pumpage and incoming streamflow, water levels would continue to decline, while streamflow rates would essentially stabilize. Model projections also indicate that water-level declines and streamflow reductions would stabilize or reverse during 1980-82 if one of the following conditions prevailed: (1) Monthly precipitation increased to 25 percent greater than normal for 3 years, (2) pumpage decreased to 50 percent of the 1979 rate, or (3) incoming streamflow increased to the 1951-69 rate.

\section{REFERENCES}

Bredehoeft, J. D., and Pinder, G. F., 1970, Digital analysis of areal flow in multi-aquifer ground-water systems: A quasi three-dimensional model: Water Resources Research, v. 6, no. 3, p. 883-888.

Cooley, R. L., 1977, A method of estimating parameters and assessing reliability for models of steady state ground-water flow: Water Resources Research, v. 13, no. 2, p. 318-324.

Cruff, R. W., and Thompson, T. H., 1967, A comparison of methods of estimating potential evapotranspiration from climatological data in arid and subhumid environments: U.S. Geological Survey Water-Supply Paper 1839-M, 27 p.

Desai, C. S., and Abel, J. F., 1972, Introduction to the finite element method: New York, Van Nostrand Reinhold, 477 p.

Dunlap, L. E., 1980, Simulated water-level declines near Marienthal, west-central Kansas: U.S. Geological Survey Water-Resources Investigations 80-39, 15 p.

Grubb, H. F., and Zehner, H. H., 1973, Aquifer diffusivity of the Ohio River alluvial aquifer by the flood-wave response method: U.S. Geological Survey Journal of Research, v. 1, no. 5, p. 597-601.

Gutentag, E. D., Lobmeyer, D. H., and McGovern, H. E., 1972, Groundwater in Kearny County, southwestern Kansas: U.S. Geological Survey Hydrologic Investigations Atlas HA-416.

Jacob, C. E., 1944, Notes on determining permeability by pumping on water table conditions: U.S. Geological Survey open file report, $25 \mathrm{p}$. 

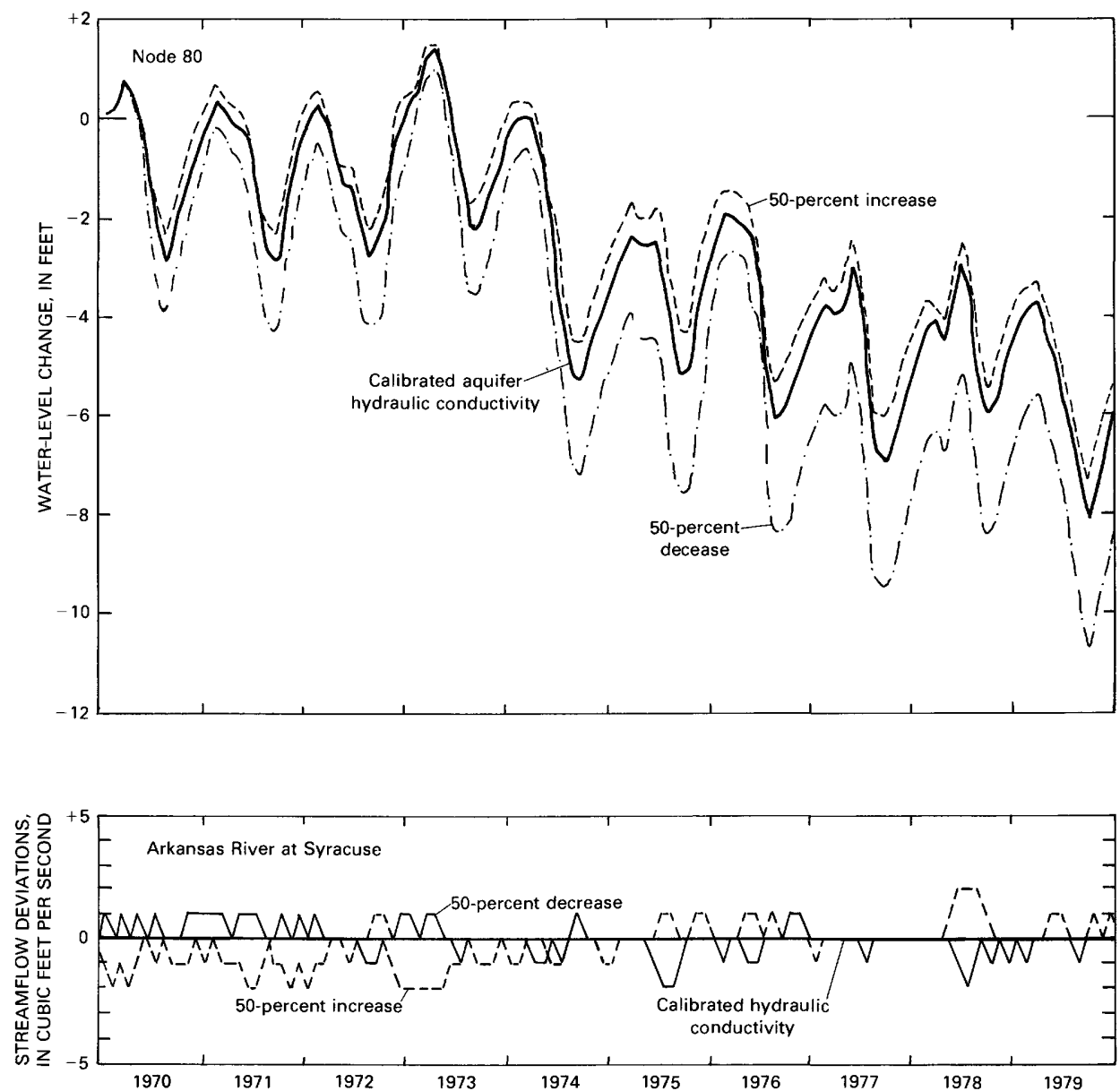

Figure 51. Typical effects on simulated water levels and streamflow, resulting from an increase and decrease in values of aquifer hydraulic conductivity.

Jenkins, C. T., 1970, Computation of rate and volume of stream depletion by wells: U.S. Geological Survey Techniques of Water-Resources Investigations, book 4, chap. D-1, 17 p.

Jenkins, C. T., and Taylor, O. J., 1972, Stream depletion factors, Arkansas River Valley, southeastern Colorado, a basis for evaluating plans for conjunctive use of ground- and surface-water: U.S. Geological Survey open-file report, $21 \mathrm{p}$. 1974, A special planning technique for stream-aquifer systems: U.S. Geological Survey Open-File Report 74-242, $25 \mathrm{p}$.

Lobmeyer, D. H., and Sauer, C. G., 1974, Water resources of Hamilton County, southwestern Kansas: U.S. Geological Survey Hydrologic Investigations Atlas HA-516.

McClain, T. J., and Jenkins, E. D., 1970, Digital simulation of the Ogallala Aquifer in Sherman County, northwestern Kansas: Ogallala Aquifer Symposium, Texas Tech. University, Special Report No. 39, p. 72-88. 

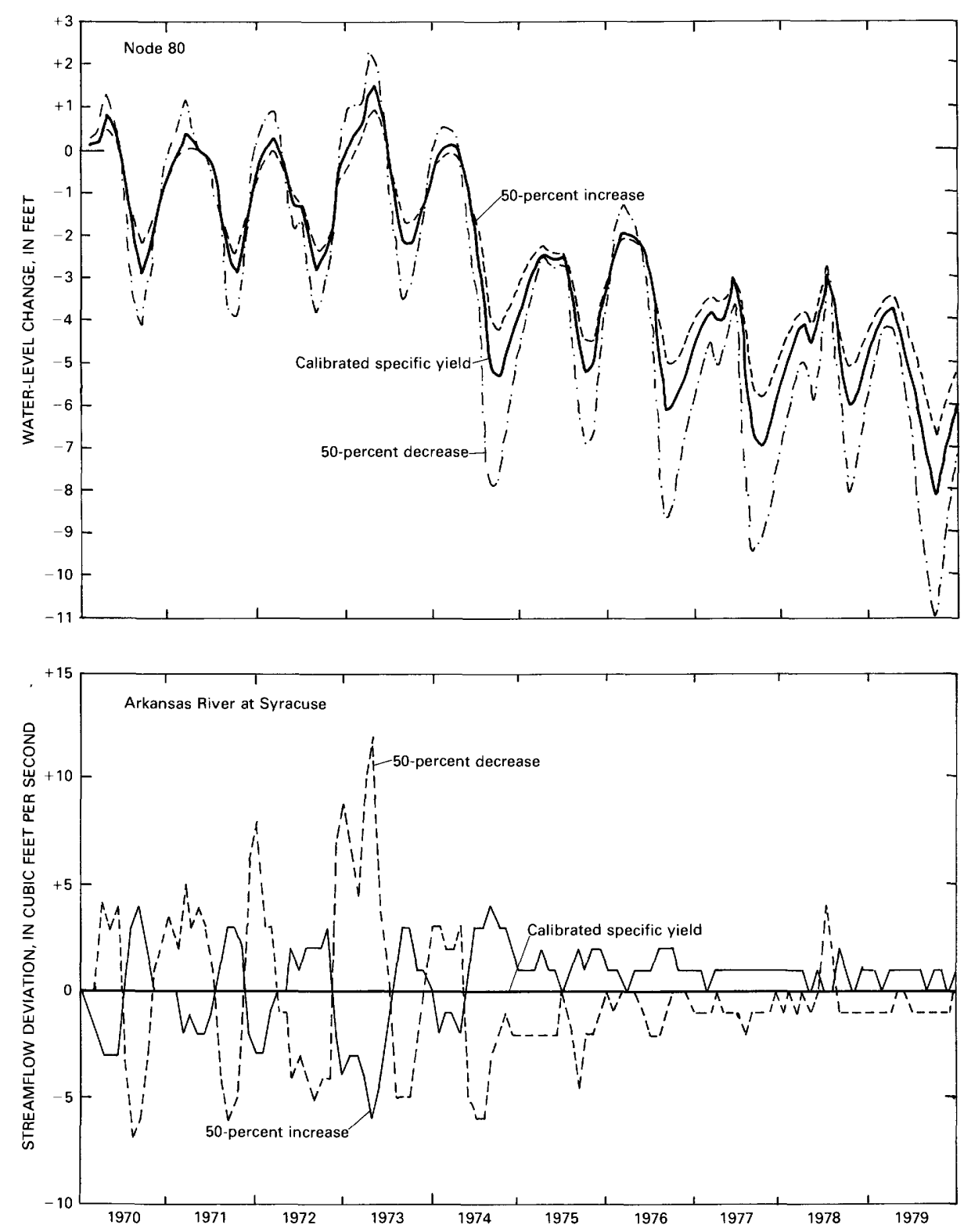

Figure 52. Typical effects on simulated water levels and streamflow, resulting from an increase and decrease in values of aquifer specific yield. 

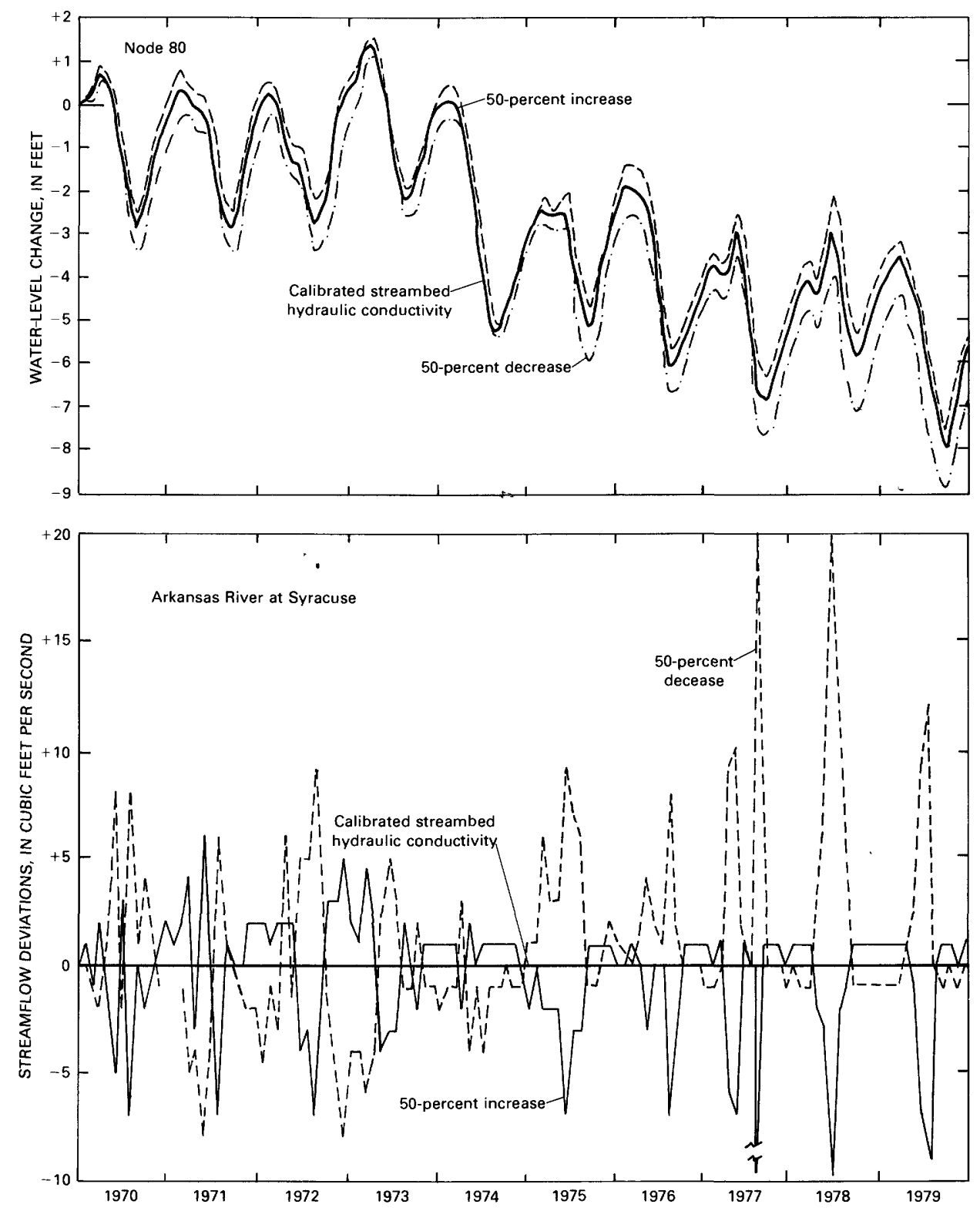

Figure 53. Typical effects on simulated water levels and streamflow, resulting from an increase and decrease in values of streambed leakance. 

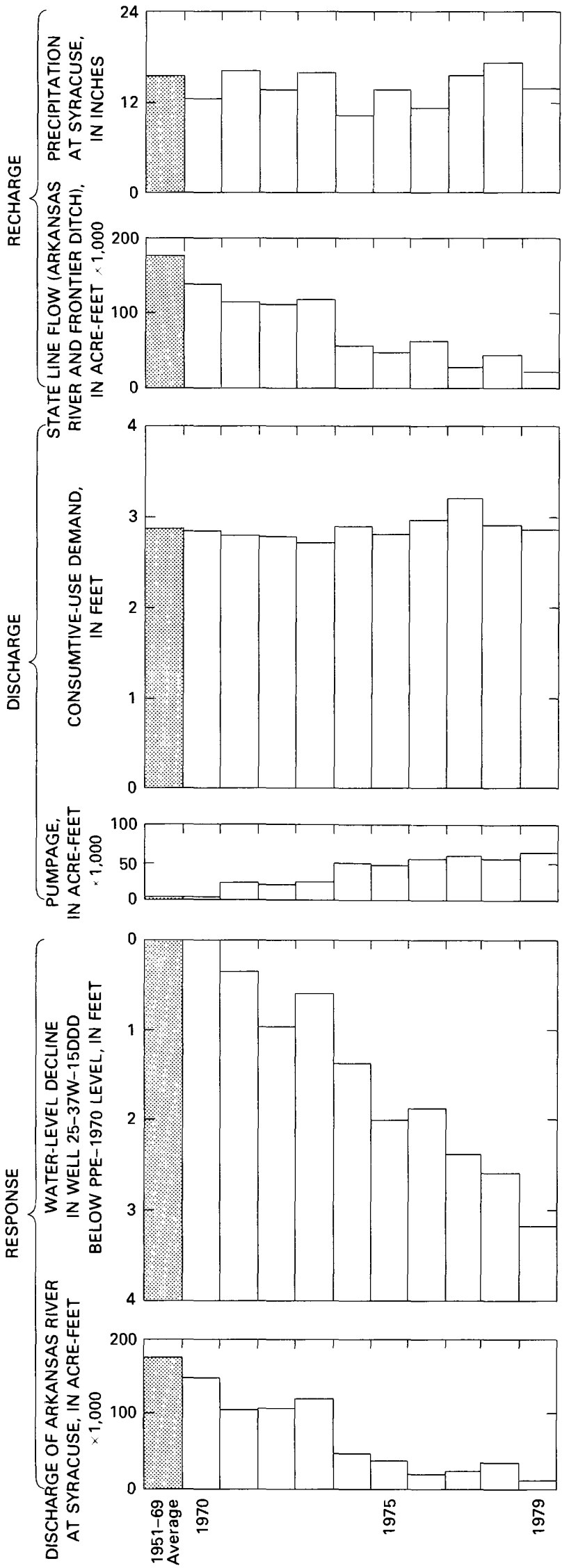

McClelland, E. J., 1963, Methods of estimating ground-water pumpage in California: U. S. Geological Survey open file report, p. 9-10.

McLaughlin, T. G., 1943, Geology and ground-water resources of Hamilton nd Kearny Counties, Kansas: Kansas Geological Survey Bulletin 49, 220 p.

Moore, J. E., and Jenkins, C. T., 1966, An evaluation of the effect of ground-water pumpage on the infiltration rate of a semipervious streambed: Water Resources Research, v. 2 , no. 4 , p. $691-696$.

Moore, J. E., and Wood, L. A., 1967, Data requirements and preliminary results of an analog-model evaluation-Arkansas River Valley in eastern Colorado: Groundwater, v. 5, no. 1, p. 20-23.

National Oceanic and Atmospheric Administration, Climatological Data, 1940-80, National Climatic Center monthly report.

Ogilbee, W., and Mitten, H., 1970, A continuing program for estimating ground-water pumpage in California-Methods: U.S. Geological Survey open-file report, 22 p.

Sandberg, G. W., 1966, Two simplified variations of a method for computing ground-water pumpage, in Mesnier, G. N., and Chase, E. B., Selected techniques in water resources investigations, 1965: U.S. Geological Survey Water-Supply Paper 1822, p. 114-117.

Schleusener, P. E., and Sulek, J. J., 1959, Criteria for appraising performance of irrigation pumping plant: Agricultural Engineering, v. 40, no. 9, p. 550-551.

Taylor, O. J., and Luckey, R. R., 1974, Water-management studies of a stream-aquifer system, Arkansas River Valley, Colorado: Ground Water, v. 12, no. 1, p. 22-38.

Texas Tech University, 1970, Ogallala aquifer symposium: Special Report 39, 88 p.

Theis, C. V., 1935, The relation between the lowering of the piezometric surface and the rate and duration of discharge of a well using ground-water storage: American Geophysical Union Transactions, v. 16, p. 519-524.

-1963, Estimating the transmissibility of a water-table aquifer from the specific capacity of a well, in Bentall, Ray, compiler, Methods of determining permeability, transmissibility, and drawdown: U.S. Geological Survey WaterSupply Paper 1536-I, p. 332-336.

U.S. Department of Agriculture, Soil Conservation Service, 1961, Soil survey, Hamilton County, Kansas: ser. 1958, no. $10,43 \mathrm{p}$.

-1963, Soil survey, Kearny County, Kansas: ser. 1959, no. $32,72 \mathrm{p}$.

1967, Irrigation water requirements: Technical Release $21,88 \mathrm{p}$.

U.S. Geological Survey, 1978, Water resources investigations in Kansas, 1978: U.S. Geological Survey, Water Index Folder.

Weaver, W., Jr., 1967, Computer programs for structural analysis: Princeton, N. J., D. Van Nostrand, 300 p.

Figure 54. Summary of recharge, discharge, and hydraulic response of stream-aquifer system in modeled area, 1951-79. 
